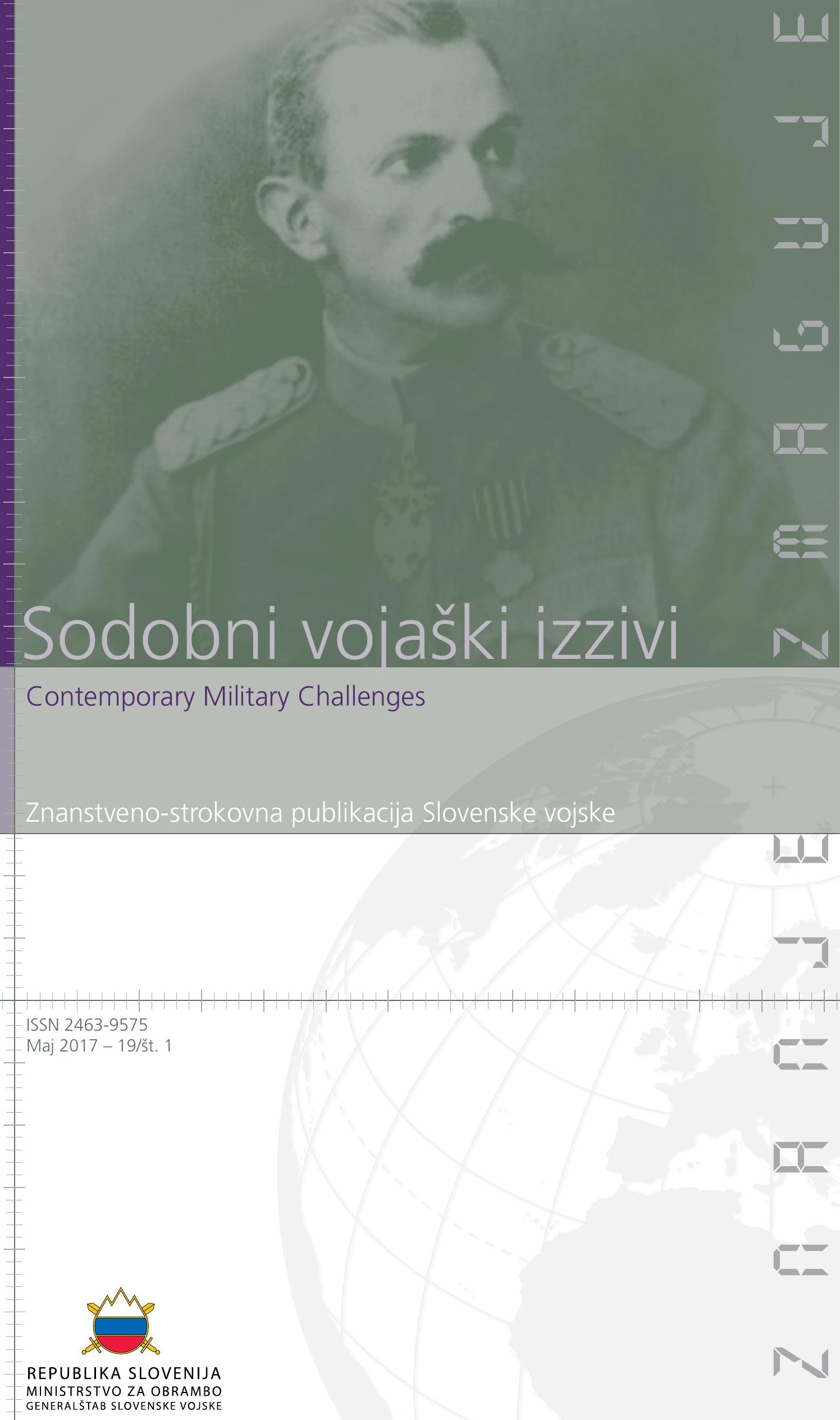




\section{Sodobni vojaški izzivi}

Contemporary Military Challenges

Znanstveno-strokovna publikacija Slovenske vojske

ISSN 2463-9575

UDK 355.5(479.4)(055)

Maj 2017 - 19/št. 1

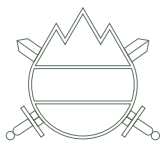




\section{Izdajatelj \\ Publisher}

Glavni urednik

Executive Editor

Odgovorni urednik

Managing Editor

Uredniški odbor

Editorial Board

Sekretar

Secretary

Uredniški svet

Editorial Council

\section{Prevajanje}

Translation

Lektoriranje

Proofreading

Oblikovanje

Design \& Graphic

Tisk

Print

ISSN

Naklada

Edition

Revija je dostopna

na spletni strani

Publication web page

E-naslov urednice

Managing Editor

e-mail address
Generalštab Slovenske vojske

General Staff of the Slovenian Armed Forces

generalmajor Alan Geder (OF-7)

dr. Liliana Brožič

višja vojaška uslužbenka XIII. razreda dr. Valerija Bernik (OF-4)

višji vojaški uslužbenec XIV. razreda dr. Denis Ćaleta (OF-5)

polkovnik dr. Tomaž Kladnik (OF-5)

dr. Igor Kotnik

dr. Maja Garb

dr. Tibor Szvircsev Tresh, Militärakademie an der ETH, Zürich

dr. Thomas Young, Center for Civil-Military Relations, Monterey

višja praporščakinja Nataša Cankar (OR-9)

dr. Andrej Anžič, Evropska pravna fakulteta, Nova Gorica

dr. Gorazd Bajc, Narodna in študijska knjižnica, Trst

dr. Anton Bebler, Fakulteta za družbene vede, Ljubljana

dr. Damir Črnčec, Fakulteta za državne in evropske študije, Brdo

dr. Bastian Giegerich, International Institute for Strategic Studies, London

dr. Olivera Injac, Univerzitet Donja Gorica, Podgorica

dr. Sergei Konoplyev, Harward University, Cambridge

generalmajor v pokoju Ladislav Lipič (OF-7, ret.)

dr. Julie T. Manta, US Army War College, Carlise

dr. Thomas Mockaitis, DePaul University, Chicago

dr. Klaus Olshausen (OF-8, ret.), Clausewitz-Gesellschaft e.V., Hamburg

generalpodpolkovnik dr. Iztok Podbregar (OF-8), Fakulteta za organizacijske vede, Kranj

Iris Žnidarič

Služba za strateško komuniciranje

Skupina Opus Design

Prima Print d.o.o.

2232-2825 (tiskana različica/print version)

2463-9575 (spletna različica/ on line version)

$300 \mathrm{izvodov/copies}$

Izhaja štirikrat na leto/ Four issues per year

http://www.slovenskavojska.si/publikacije/sodobni-vojaski-izzivi/

http://www.slovenskavojska.si/en/publications/contemporary-military-challenges/

liliana.brozic@mors.si

Prispevki, objavljeni v Sodobnih vojaških izzivih, niso uradno stališče

Slovenske vojske niti organov, iz katerih so avtorji prispevkov.

Publikacija je uvrščena v bibliografsko zbirko podatkov COBISS.SI

in PAIS International.

Articles, published in the Contemporary Military Challenges do not reflect the official viewpoint of the Slovenian Armed Forces nor the bodies in which the authors of articles are employed.

The publication is indexed in bibliography databases COBISS.SI

and PAIS International. 


\section{VARNOST KOT IMPERATIV}

"Zagotavljanje varnosti danes pa ni zgolj vojaško-politično, ampak tudi temeljno kulturno in civilizacijsko vprašanje, ki ga sodobne razvite države rešujejo celostno, z jasno razvojno vizijo in strategijo, s katerima dosegajo potrebno družbeno motivacijo, kohezijo, varnost in blaginjo državljank in državljanov."

Monika Kalin Golob, Anton Grizold, Obrambna prvina nacionalne varnosti Slovenije v primežu Obveščevalno-varnostne službe, politike in medijev. Teorija in praksa 1/2017, str. 92-111.

\section{SECURITY AS AN IMPERATIVE}

»Nowadays, security provision is not merely a military and political issue, but also a basic cultural and civilizational one. It is addressed by modern developed countries in a comprehensive manner and with a clear development vision and strategy, which helps to obtain the necessary social motivation, cohesion, as well as the citizens' security and abundance."

Monika Kalin Golob, Anton Grizold, Obrambna prvina nacionalne varnosti Slovenije v primežu Obveščevalno-varnostne službe, politike in medijev. Teorija in praksa 1/2017, pp. 92-111. 



\section{VSEBINA}

CONTENTS

7

Liliana Brožič

UVODNIK

VARNOST KOT IMPERATIV

11

EDITORIAL

SECURITY AS AN IMPERATIVE

15

Pavel Vuk

OBRAMBNO PLANIRANJE - NUJEN INSTRUMENT POLITIKE PRI ZAGOTAVLJANJU OBRAMBNIH POTREB DRŽAVE

DEFENCE PLANNING - VITAL POLICY INSTRUMENT IN SUPPORTING A NATION'S DEFENCE NEEDS

35

Nina Raduha

KRIZNO UPRAVLJANJE NA OBRAMBNEM PODROČJU S POUDARKOM NA SLOVENSKI VOJSKI

CRISIS MANAGEMENT IN THE FIELD OF DEFENCE, WITH EMPHASIS ON THE SLOVENIAN ARMED FORCES 
57

Viktor Potočnik

ČETRTA GENERACIJA VOJSKOVANJA

3. del: NOV KONCEPT SV ZA DELOVANJE V ČETRTI GENERACIJI VOJSKOVANJA

FOURTH GENERATION WARFARE

Part 3: NEW SAF CONCEPT OF OPERATIONS IN FOURTH GENERATION WARFARE

\section{7}

Vinko Vegič

TEMELJNO ŠOLANJE ČASTNIKOV V DRŽAVAH EVROPSKE UNIJE ISKANJE ODGOVOROV NA SODOBNE ZAHTEVE BASIC OFFICER TRAINING IN EUROPEAN UNION COUNTRIES SEEKING ANSWERS TO CONTEMPORARY REQUIREMENTS

\section{5}

Tomaž Kladnik

VOJAŠKO IZOBRAŽEVANJE V SLOVENSKI VOJSKI - IZZIVI PRIHODNOSTI MILITARY EDUCATION IN THE SLOVENIAN ARMED FORCES - FUTURE CHALLENGES

115

AVTORJI

AUTHORS

119

NAVODILA AVTORJEM ZA OBLIKOVANJE PRISPEVKOV

125

INSTRUCTIONS FOR THE AUTHORS OF PAPERS 


\section{UVODNIK}

\section{VARNOST KOT IMPERATIV}

Sodobni vojaški izzivi leta 2017 vstopajo v devetnajsto leto izhajanja, kar nas opozarja na pomembno obletnico leta 2018. Prva številka je izšla septembra 1999, in sicer kot Bilten Slovenske vojske. Od takrat do konca lanskega leta je bilo v 18 letnikih objavljenih 438 prispevkov, ki jih je napisalo 564 avtorjev. Iz Slovenske vojske je bilo 289 avtorjev, iz upravnega dela ministrstva pa 48. Drugih avtorjev iz različnih ustanov je bilo 161, iz tujine pa 66.

Letos se bomo posvetili aktualnim temam, za katere upamo, da bodo zanimive in bomo vas, bralce, $\mathrm{z}$ njimi spodbudili k razpravi, razmišljanju in morda tudi k pisanju o svojih pogledih na nastajanje nove varnosti kot imperativa za prihodnost.

Druga letošnja številka bo imela naslov Veteranske organizacije - ali jih sploh potrebujemo, izšla bo v angleškem jeziku. Te teme v zgodovini publikacije še nismo obravnavali, zato je morda tokrat pravi čas tudi zanjo in za izmenjavo izkušenj med različnimi državami.

Tudi tretja številka letošnjega letnika bo angleška, njen naslov bo Migracije in varnost na stari celini. Posvečena bo nemirnemu Bližnjemu vzhodu, terorizmu v Evropi in nacionalnim izkušnjam z migracijami, s poudarkom na migracijah od jeseni 2015 do pomladi 2016, ter evropskim odzivom nanje.

Naslov četrte številke bo Varnostne sile prihodnosti, v njej pa bo poudarek na tem, kako naprej pri zagotavljanju varnosti. Med aktualnejšimi temami bodo zagotovo novi stari načini popolnjevanja oboroženih sil, doseganje ciljev zmogljivosti sil ter mednarodne operacije in misije. Letos mineva tudi 20 let, odkar so se pripadnice in pripadniki Slovenske vojske prvič pridružili mednarodni operaciji, to je bila operacija Alba v Albaniji. Od takrat so sodelovali v številnih operacijah in na misijah po svetu. 
Leto 2017 bo nedvomno zaznamovano z ugotovitvami Strateškega pregleda obrambe 2016, in nalogami, ki iz njega izhajajo. V poglavju o krepitvi obrambne sposobnosti in odpornosti so določeni glavni cilj nadaljnjega razvoja obrambnega sistema in obrambne sposobnosti Republike Slovenije, ki izhajajo iz ugotovitev strateškega pregleda in so jih avtorji dokumenta razvrstili v zagotovitev potrebnih obrambnih zmogljivosti države, večjo odpornost države in družbe pred varnostnimi grožnjami, izboljšanje pripravljenosti in vzdržljivosti Slovenske vojske ter uresničevanje skupnih ciljev in zavez znotraj EU in Nata.

Prepričani smo, da bodo članki iz tokratne številke Sodobnih vojaških izzivov z naslovom Varnost kot imperativ lahko prispevali k ciljem, ki so zapisani v Strateškem pregledu obrambe.

Obrambo planiranje - nujen instrument politike pri zagotavljanju obrambnih potreb države je naslov članka, ki ga je napisal Pavel Vuk. V sklepnem delu ugotavlja, da bi moralo biti osrednje vprašanje politike, ko z vidika omejenih ekonomskih zmožnosti govorimo o prihodnjih obrambnih potrebah države, vselej usmerjeno v obrambno planiranje. Zanimati bi jo moral predvsem odgovor na temeljno vprašanje, ali bo predlagani načrt ponudil dovolj dobre odgovore za prihodnje nacionalne obrambne potrebe.

Nina Raduha in Pavel Vuk sta avtorja članka Krizno upravljanje na obrambnem področju, s poudarkom $v$ Slovenski vojski. V njem polemizirata in opozarjata na to, da je skrb, ki se na tem področju pojavlja, povezana s prestižno miselnostjo ključnih odločevalcev o vključevanju Slovenske vojske v kriznih razmerah, kar se kot posledica pogosto kaže v njenem prepoznem aktiviranju oziroma njenem premajhnem obsegu.

V tej številki svojo trilogijo o četrti generaciji vojskovanja končuje Viktor Potočnik. Tokratni naslov prispevka je Četrta generacija vojskovanja, 3. del: Nov koncept SV za delovanje v četrti generaciji vojskovanja. V njem se je avtor v sklepnem delu posvetil področjem izobraževanja, usposabljanja, organizacije in strukture ter popolnjevanja SV. Med njegovimi sklepnimi mislimi je tudi misel, da priprava nujnih sprememb in razmislek o njih ne zahtevata posebnih virov, zahtevata pa intenzivno komunikacijo SV s politiko in družbo, ki mora temeljiti na strokovnih podlagah.

Pojmovnim opredelitvam vojaškega izobraževanja in usposabljanja se je posvetil Vinko Vegič v članku z naslovom Temeljno šolanje častnikov v državah Evropske unije - iskanje odgovorov na sodobne zahteve. Pripravil je primerjalno analizo razumevanja med različnimi avtorji in načinom vojaškega izobraževana in usposabljanja v nekaterih državah. Bistvene so njegove ugotovitve o Sloveniji in SV. 
O organizacijskih vidikih vojaškega izobraževanja in usposabljanja piše Tomaž Kladnik v članku z naslovom Vojaško izobraževanje v Slovenski vojski - izzivi prihodnosti. V ospredje umešča razvoj vojaške stroke in znanosti, ju primerja $\mathrm{z}$ javnim izobraževalnim sistemom in opozarja na nove izzive.

Vabljeni k sodelovanju! 


\section{EDITORIAL}

\section{SECURITY AS AN IMPERATIVE}

In 2017, the publication Contemporary Military Challenges entered its nineteenth year of existence, which reminds us of an important anniversary coming up in 2018. The first issue was published in September 1999 under the name of Bulletin of the Slovenian Armed Forces. From then until the end of last year, 18 volumes of the publication included 438 articles by 564 authors. There were 289 authors from the Slovenian Armed Forces and 48 authors from the administrative part of the Ministry of Defence; 161 authors were from different institutions and 66 authors from abroad.

This year, we will focus on topical issues, which will, hopefully, be of interest to our readers and will motivate you to open discussions, reflect upon and perhaps even write about your views on the emergence of new security as an imperative for the future.

This year's second issue titled Veteran organizations - are they even needed will be released in English. Since this topic has never before been discussed in our publication, it is perhaps time that we speak about it and share experiences of different countries.

This year's third issue titled Migrations and security on the Old Continent will also be published in English. It will be dedicated to the unstable Middle East, terrorism in Europe and national experiences with migration. Special focus will be put on the migration flows from autumn 2015 to spring 2016 as well on to the Europe's response to them.

The title of the fourth issue will be Security forces of the future. It will focus on the way forward in ensuring safety. Some of the topical issues will certainly include the new old ways of manning the armed forces, achieving capability targets and international operations and missions. This year also marks 20 years since members 
of the Slovenian Armed Forces have joined an international operation for the first time. It was Operation Alba in Albania. Since then, they have participated in numerous operations and missions throughout the world.

The year 2017 will undoubtedly also be marked by the findings of the 2016 Strategic Defence Review, and the tasks arising from it. The chapter referring to the strengthening of the defence capability and resilience defines the primary objective of further development of the defence system and defence capacity of the Republic of Slovenia, which arises from the findings of the strategic review. The authors of the document classified them as follows: provision of the country's defence capabilities, enhancing the resilience of the state and society to security threats, improving the preparedness and sustainability of the Slovenian Armed Forces, and achieving of common goals and commitments in the framework of the EU and NATO.

It is our firm belief that the articles in this issue of the Contemporary Military Challenges titled Security as an imperative can contribute to the goals set out in the Strategic Defence Review.

Defence planning - vital policy instrument in supporting a nation's defence needs is the title of the article written by Pavel Vuk. In the final part of the article, the author writes that the main question of the politics when discussing future defence needs of a county from the perspective of limited economic ability should always focus on defence planning. It should primarily attempt to find the answer to the fundamental question of whether the proposed plan will offer adequate answers to the future national defence needs.

Nina Raduha and Pavel Vuk are the authors of the article Crisis management in the field of defence, with emphasis on the Slovenian Armed Forces. They open the polemics and point out that the concern raised in this area is associated with a prestigious mentality of key decision-makers regarding the integration of the Slovenian Armed Forces in crisis situations. This often results in its belated activation or undersized scope.

In this issue, Viktor Potočnik concludes his trilogy on the fourth generation warfare. The title of his article is Fourth generation warfare, Part 3: New SAF concept of operations in fourth generation warfare. The author dedicates the conclusion of his article to the areas of education, training, organization, structure, and manning of the Slovenian Armed Forces. His final thoughts also include a view that the preparation of the necessary changes and a reflection on them do not require special resources; however, they do require intensive communication of the Slovenian Armed Forces with the politics and the society, which should be based on professional grounds.

Conceptual definitions of military education and training have been discussed by Vinko Vegič in his article titled Basic officer training in European Union countries seeking answers to contemporary requirements. He has prepared a comparative 
analysis of understanding among different authors and the methods of military education and training in some countries. His findings on Slovenia and the Slovenian Armed Forces are crucial.

The organizational aspects of military education and training are discussed by Tomaž Kladnik who wrote the article titled Military education in the Slovenian Armed Forces - future challenges. He puts into the foreground the development of military science and profession, comparing them with the public education system and highlighting the new challenges.

You are kindly invited to participate! 


\title{
OBRAMBNO PLANIRANJE - NUJEN INSTRUMENT POLITIKE PRI ZAGOTAVLJANJU OBRAMBNIH POTREB DRŽAVE
}

\author{
DEFENCE PLANNING - VITAL POLICY \\ INSTRUMENT IN SUPPORTING A NATION'S \\ DEFENCE NEEDS
}

Povzetek V prispevku predstavljamo znanstvena in aplikativna spoznanja pomembnih teoretikov in avtorjev 19., 20. in 21. stoletja s področij teorije strategije, teorije in filozofije vojne in vojskovanja ter vojaške zgodovine, ki so pripomogli $\mathrm{k}$ prepoznavanju in utrjevanju pomena obrambnega planiranja (Carl von Clausewitz, Liddell Hart, Bernard Brodie, Colin S. Gray, Harry R. Yarger, Williamson Murray in drugi). Na podlagi analize njihovih teoretičnih spoznanj proučujemo nujnost razvijanja strateške misli v obrambnem planiranju in nujnost obstoja obrambnega planiranja. Ta je $\mathrm{v}$ sodobnem svetu prepoznan kot eden od najučinkovitejših instrumentov države pri zagotavljanju njenih obrambnih potreb in obvladovanju negotove prihodnosti nacionalne varnosti.

\section{Ključne} besede

\section{Politika, strategija, obrambno planiranje.}

Abstract The article presents scientific and applicative findings of important $19^{\text {th }}, 20^{\text {th }}$ and $21^{\text {st }}$ century theoreticians and authors in the field of strategy theory, war and warfare theory and philosophy, and military history, who have contributed to the acknowledgment and reinforced importance of defence planning (Carl von Clausewitz, Liddell Hart, Bernard Brodie, Colin S. Gray, Harry R. Yarger, Williamson Murray et al.). On the basis of the analysis of their theoretical findings, we examine the urgency of developing a strategic thought in defence planning and the urgency of its existence. In the contemporary settings, defence planning is recognised as one of the most effective national instruments in the support of its defence needs and management of national security's uncertain future. 


\section{Uvod Izhodiščna vprašanja o kontekstu obrambnega planiranja}

Bistvo obrambnega planiranja je $\mathrm{v}$ najbolj splošnem smislu predvidevanje ${ }^{1}$. Pri predvidevanju, še posebno pri tako pomembnih zadevah, kot je obrambno prizadevanje države, ne odkrivamo prihodnosti, temveč poskušamo pokazati mogočo prihodnost. V obrambnem planiranju in z njim povezanimi proračunskimi aktivnostmi je neizogibno predvidevanje glede prihodnosti, na katero lahko na podlagi možnosti izbire in posledičnega ignoriranja drugih možnosti močno (nepredvidljivo) vplivamo. Ignoriranje nekaterih možnosti pri opredeljevanju prihodnosti v procesu obrambnega planiranja ustvarja vprašanja obrambnim planerjem, ki jih bomo v tem prispevku poskušali pojasniti. Prispevek temelji na tezi, da ni mogoče pripraviti plana, ki bi bil absoluten in »pravi« za prihodnost, saj je takšno védenje pravzaprav nemogoče.

Ne glede na to, da ne obstaja nobena zanesljiva strokovna metoda, ki bi jo lahko preprosto uporabili pri planiranju prihodnosti, in da se pri tem soočamo $\mathrm{s}$ predvidevanjem, z znanim in neznanim, obrambno planiranje mora biti izvedeno. Iz tega lahko sklepamo, da je v znanstvenem raziskovanju obrambne dejavnosti, še posebno v okviru uporabe znanstvenoraziskovalnega dela v obrambnih pripravah, ki so, kot pravi Grizold (1989, str. 1613-1616), temeljni dejavnik obrambne moči družbe, še precej neraziskanega področja za znanstvena dognanja, temelječa zlasti na kvantitativnih metodah, ki bi lahko komplementarno prispevale k teoretičnim izhodiščem za razvoj obrambnega področja. Hkrati se moramo zavedati, da vsi dosežki politike in strategije niso vselej primerni za izvedbo prepričljivih znanstvenih analiz, ki bi bile preverljive s testiranjem. Človekova politična presoja individualna ali kolektivna, prijateljska ali sovražna - lahko na primer odločilno vpliva na spreminjanje racionalnega procesa zaradi subjektivnega in neracionalnega vedenja ${ }^{2}$.

Priproučevanju koncepta obrambnega planiranja izhajamo iznjegove funkcionalnosti, nujne zgodovinske podobnosti pa bomo iskali le pri proučevanju (dis)kontinuitete,

\footnotetext{
V slovenski strokovni literaturi, zlasti s področja menedžmenta, ki najbolj temeljito obravnava strateško planiranje, je najpogosteje uporabljen izraz »predvidevanje« (na primer Možina (et al.), 2002, Rozman (et al.), 1993, Tavčar, 2005). Slovar slovenskega knjižnega jezika razlaga njegov pomen v dveh različicah; (1) »na osnovi določenih dogodkov, pojavov biti prepričan o uresničitvi česa (npr. vnaprej predvideti konec vojne) in (2) »na osnovi določenih potreb, želj vnaprej določati, upoštevati« (npr. predvidevati vzpostavitev zmogljivosti). Pomen slednje različice je najbolj povezan z bistvom strateškega planiranja, kot ga obravnavamo v prispevku. $V$ tujih znanstvenih in strokovnih delih, ki obravnavajo različne vidike obrambnega planiranja, se uporablja tudi izraz »ugibanje" (angl. gueswork) (Gray, 2014 a, 2014 b, 2010). Izraz v slovenskem izrazoslovju zveni nekoliko skrivnostno, povezano s preveč neznankami, nedoumljivostjo, ki bi lahko strateško oziroma obrambno planiranje prikazale v slabšalni obliki in relativizaciji njegove pomembnosti, čeprav so po razlagi Slovarja slovenskega knjižnega jezika sestavine ugibanja tudi naključje in intuicija, ki so, kot je to predstavljeno $v$ prispevku, prav tako pomembni, zlasti pri strateškem odločanju.

2 Narava človeka in spremenljiv značaj ljudi, ki sodelujejo v obrambnem planiranju, nenehno nihata med neracionalnostjo in razumom. Po eni strani je lahko na primer racionalno vedenje pri uresničevanju ambicij, ki izhajajo iz vizije in vrednot, smotrno, po drugi strani pa je lahko absurdno in celo moralno sporno (Gray, 2014 b, str. 15). Z vidika dveh najpomembnejših lastnosti narave človeka so takšna dejanja človeka razumljiva, saj je učljiv in lahko sprejme informacije iz okolja, ki jih nato izživi nazaj v okolje; torej lahko spreminja svoj način delovanja, vedenja, čutenja in razmišljanja.
} 
ki bi lahko problem bolje razjasnila in razumela. S takšno predpostavko želimo raziskovanje usmeriti na bistvo obrambnega planiranja skozi čas, prostor, politiko, kulturo in tehnologijo. Ne glede na bolj ali manj napredno usmerjenost tega prispevka po boljšem razumevanju koristnosti obrambnega planiranja pri nacionalnovarnostnih prizadevanjih države se opiramo tudi na celovitost proučevanja obrambnega planiranja z vidika njegove relevantnosti. V prispevku so obravnavana tudi nekatera vodilna načela kot okvir za razmišljanje in ključna vprašanja, ki bi jih bilo treba ustrezno obravnavati tudi $\mathrm{v}$ slovenskem prostoru $\mathrm{v}$ kontekstu teoretičnega in praktičnega razumevanja kompleksnosti sodobnega procesa obrambnega planiranja.

\section{OBRAMBNO PLANIRANJE SKOZI ZGODOVINSKO PERSPEKTIVO}

Vojaški zgodovinar Murray (Gray, 2014 b, str. 13) pravi, da je bilo v obdobjih antike in srednjega veka razumevanje velike (grand) in vojaške strategije $\mathrm{e}^{3}$ zelo preprosto. Zato dopušča možnost razlage, da pred 18. stoletjem ni bilo koncepta, kot ga poznamo danes pod pojmom »strateško planiranje«. Murray (prav tam) povezuje izvor sodobnega strateškega planiranja glede na zgodovinske ocene in dokazljivost z naraščajočimi potrebami vojaške logistike in tehnološkim razvojem orožja, ki so vedno predstavljali meje operativnih, strateških in političnih zmožnosti.

Veliko avtorjev (Gray, 2014 b, Creveld, 1977, Kane, 2001) prepoznava vzpostavitev koncepta obrambnega planiranja šele v drugi polovici 19. stoletja, ko se je radikalno preoblikovalo vojaško planiranje, ki se je nato dve stoletji razvijalo ter kvalitativno posodabljalo in prilagajalo zahtevam sodobnega časa. Po končani prusko-avstrijski vojni leta 1866 in francosko-pruski vojni leta 1871 se je večina evropskih vojsk zavedala potrebe po izšolanih štabnih častnikih in po oblikovanju močnega generalštaba, sposobnega soočiti se z zahtevami sodobnega bojevanja. Nadvse pomembno je postalo sistematično in načrtno planiranje vseh faz vojne in bojevanja, pri čemer je bilo najpomembnejše skrajšanje teh planskih procesov, saj je čas mobilizacije postal osrednji dejavnik vojaškega planiranja (Stergar, 2004, str. 17-18). Prusija je z razvojem vrhovnega poveljstva (generalštaba), odgovornega za planiranje in izvedbo obsežnega vojskovanja, postala vzor številnim državam. Francija je na primer leta 1880 ustanovila svojo »École de Guerre«. Tudi ZDA in Britanija sta, čeprav ne z veliko naklonjenostjo, vpeljali planiranje kot profesionalno funkcijo, ki so ga v britanskem primeru pospešile šele boleče izkušnje iz 2. burske vojne (1899-1902). Te izkušnje so povzročile velike vojaške reforme Britanije, uvedbo načelnika imperialnega generalštaba ter podrobno planiranje mobilizacije ob vojni (več o tem Hodgson, 2009, Grant, 2014, 2016, Benko, 1997).

\footnotetext{
Pomen in hierarhična raven strategij sta podrobneje predstavljena v Vuk, 2016, str. 29. V tem prispevku bomo izraz »velike (grand) « strategije uporabljali v najširšem pomenu besede. V strokovni literaturi se takšnim splošnim strategijam, s katerimi se ukvarjajo najvišja državna vodstva, ki imajo v rokah vse vzvode državne moči, pogosto doda pridevnik velika, nacionalna (ali grand) strategija. Žabkar (2003, str. 183) takšno strategijo označuje z metastrategijo, ki usmerja politično, vojaško, gospodarsko, diplomatsko strategijo in vse druge parcialne strategije.
} 
Učinek obrambnega planiranja kot profesionalne funkcije je bil razviden $\mathrm{v}$ večnacionalnih izkušnjah iz leta 1914, ki je povzročil celo, da so podrobno oblikovali predvojne načrte ter napisali scenarij za vseevropsko vojno, ki bi jo lahko v vsakem trenutku sprožil samo en incident (Grant, 2014, str. 22-23). Obsežnost in trajanje prve svetovne vojne so tako omogočale zlasti sposobnosti vojaških in civilnih planerjev, ki so znali izkoristiti učinke sodobne tehnologije pri oskrbi in premikih. Zgodnji potek vojne leta 1914 kaže tako uspeh kot tudi velike omejitve predvojnega vojaškega planiranja, ravno zaradi svoje ozke vezanosti na vojaško področje pri usmerjanju vodenja sodobne velike koalicijske vojne.

Poznavanje verjetnega koncepta prihodnjega značaja vojne in vojskovanja ima neposredno korelacijo $\mathrm{z}$ učinkovitostjo obrambnega planiranja. Vprašanje pa je, »kakšna je zanesljivost vedenja o tem, kakšna bosta prihodnja vojna in način vojskovanja?«. Za prihodnost je namreč veliko možnosti, odločitev za eno izmed njih, ki naj bi se zgodila, pa je zgolj posledica naše izbire. Ta spoznanja je Gray (2014 b, str. 34) združil v trditev, da je preteklost »singularna ${ }^{4} \ll$, ne glede na pestro interpretacijo zgodovinarjev, medtem ko je prihodnost $\mathrm{z}$ današnjega vidika in kontrasta »pluralna ${ }^{5} \ll$. Za ponazoritev te trditve izpostavljamo predpostavko: četudi bi politiki in strategi v za njih relevantnem času dovolj dobro poznali značaj vojne in vojskovanja, zaradi pluralnega kontrasta prihodnosti ne bi mogli popolnoma vplivati oziroma se izogniti svetovni katastrofi v obdobju 1914-1918. Ta pluralni kontrast prihodnosti pravzaprav predstavlja nenehen izziv za obrambno planiranje.

Za velik del zgodovine lahko rečemo, da je bil nepretrgan preplet politike, diplomacije in vojskovanja dovolj stabilen, da je omogočil izvajanje in razvoj obrambnega planiranja ter zaupanje $\mathrm{v}$ njegov pomen pri doseganju ciljev. V povezavi s tem lahko obrambno planiranje razumemo kot posledico priprav na prihodnost, ki ne more biti tesno omejena samo na vojsko in gotovo ne na izključno operativne načrte vojnih operacij (ali načrte kampanj). Ti operativni načrti in ocene taktične učinkovitosti nimajo velikega pomena brez jasnega razumevanja sodobne vojne, ki jo zaznamujejo aktualne okoliščine konfliktov. Clausewitz (2004, str. 18-28) je opredelil vojno kot akt sile, ki jo vedno izzove politični motiv in nanjo tudi nenehno vpliva. Za stratege, planerje in operativne poveljnike je zelo pomembno poznavanje sodobnega značaja vojskovanja, kljub negotovostim, na katere vplivajo tudi posamezne (ali kolektivne) človekove izbire (Gray, 2014 b, str. 34). Prusija in pozneje Nemčija sta uživali zavidanja vreden ugled pri vodenju sodobnega štabnega dela in še posebno profesionalnega vojaškega obvladovanja železniškega sistema kot najpomembnejšega dejavnika izkoriščanja nemške geostrateške lokacije v Evropi. Oddaljenost francoskega in ruskega bojišča, slaba komunikacijska infrastruktura in vremenske razmere potem ne bi smeli presenetiti

\footnotetext{
V prevodu »ena, edinstvena« (op. p.).
}

V prevodu »raznolika« (op. p.). 
nemške vojske $\mathrm{v}$ prvi svetovni vojni ${ }^{6}$. Podobno težavo z dominantnostjo je imela Nemčija tudi v letih 1941-1943, ko je (1) verjela v neprekosljivost svojih oboroženih sil in neustavljiv značaj vojne ter (2) bila prepričana v šibkost bojne moči sovjetskih nasprotnikov, ki naj bi na bojišču kompenzirali napake nemške vojske. $Z$ veliko verjetnostjo lahko izpostavimo, da napake v predpostavkah, ki se odkrijejo šele s praktično izkušnjo, največkrat ne dopuščajo popravkov. Čeprav so napake v obrambnem planiranju popolnoma normalne, pa je to tudi razlog, zakaj morajo planerji vztrajati pri zavarovanju plana A s planom B (Gray, 2014 b, str. 35).

Ne glede na svoje zmožnosti in omejitve ostaja dejstvo, da obrambno planiranje ne more preprečiti ali zaustaviti vojaškega stroja pri doseganju političnega cilja. Kot primer navajamo sprejetje brezkompromisne strateške odločitve Hitlerja, ki je bil prepričan, da zmorejo njegova volja, vojaška »izkušenost « pri vodenju in celo rasna večvrednost Nemcev premagati težko prehodno in neprijazno rusko pokrajino ter rusko vojsko, ki je bila zaradi notranjih težav nagnjena h kolapsu. Napake Nemcev v prvi in drugi svetovni vojni nas ne bi smele zapeljati v sprejemanje neupravičenega determinizma, po katerem se vse razvija po objektivnih zakonih, ki so neodvisni od človekove volje in njegovega delovanja. Ljudje, živali in stroji morajo biti oskrbljeni, spočiti, vzdrževani. Obrambni planerji se morajo zavedati realnosti takšnih okoliščin, ki so lahko povsem napačne, če se pričakuje, da jih bodo pojasnili bolj, kot je to mogoče in kot so sploh zmožni.

Za obrambno planiranje je značilno načelo merljivosti planov. Številke pogosto učinkujejo kot skupen jezik nacionalne varnosti in imajo kot takšne tudi precejšnji vpliv na politične odločevalce. Vendar se številčni pomen obrambnih virov (kadrovski, finančni, materialni) bistveno razlikuje od človekove volje (morale) in izkušenosti (strateška, operativna in taktična). Poznati kvantiteto, ki se lahko v vojni številčno vrednoti, še ne pomeni tudi prepričanosti, da je politični, strateški in vojaški pomen ustrezno razumljen. Winston S. Churchill (v Gray, 2014 b, str. 36) je izjavil, da je stik z neizmerljivim dogodkom zmeraj nevaren za oblikovanje fiksnega mnenja. Obrambne zmogljivosti in njihove sposobnosti omejijo uresničevanje strategije na raven praktične zmožnosti. Podobno so tudi izzivi obrambnega planiranja vedno omejeni z ravnijo zmožnosti. Med hladno vojno so ZDA pospešeno gradile in vzdrževale jedrsko silo, ki naj bi odvrnila sovjetskega nasprotnika od tveganih namer. Vrednost jedrskega zastraševanja pa ni bila povezana $\mathrm{z}$ obsegom in vrsto škode, ki bi bila lahko povzročena, temveč z zastraševalnim učinkom na morebitno sovjetsko ravnanje. Izkazalo se je, da veliko obrambnih analitikov ni razumelo, da zastraševalne vrednosti vojaške drže ni mogoče količinsko izmeriti. Ključna spremenljivka pri tem je izbira, ki jo naredijo posamezniki v nekem obdobju (Gray, 2014 b, str. 36).

\footnotetext{
6 Kot primer lahko navedemo Schlieffnov načrt, po katerem bi bilo nujnih 42 dni, da Francija podleže Nemčiji. Vendar so bili Nemci, namesto da bi načrtovano hitro porazili Francoze, po bitki pri Marni septembra 1914 prisiljeni v umik (več o tem npr. Grant, 2014, str. 22-23).
} 
Kljub raznolikim podrobnostim, ki označujejo določeno obdobje, ostaja funkcija obrambnega planiranja v svoji naravi enaka, in sicer od križarskih vojn, Napoleonovih vojn do sodobnih konfliktov. Obrambno planiranje se je zmeraj spoprijemalo $\mathrm{z}$ obvladovanjem znanega, omejenostjo, naključno srečo in $\mathrm{S}$ spretnostjo planerjev.

\section{OBRAMBNO PLANIRANJE IN NEGOTOVOST SODOBNEGA VARNOSTNEGA OKOLIA}

Obrambno planiranje pod pogoji negotovosti predstavlja osrednji izziv obrambnim resorjem, ki ga zahteva nov geostrateški kontekst po koncu hladne vojne ${ }^{7}$. Zgodovinske izkušnje kažejo, da je imelo obrambno planiranje vedno strateški pomen, ne glede na to, ali ga je vodila politika ali vojaško vodstvo, čeprav je vloga strateške logike temeljila na priporočljivosti, in ne na funkcionalni natančnosti. Pogost dejavnik, ki vpliva na različne oblike obrambnega planiranja, je človekovo vedenje, ko je pod stresom. Pri tem bi moral biti osredotočen na veščine mogočega, kar bi moralo biti podprto z znanostjo, ki se lahko uporabi v praksi. Predpostavljamo lahko, da morajo vse politike planirati svojo prihodnjo varnost z izvajanjem obrambnega planiranja. $\mathrm{S}$ tem razumemo planiranje vnaprej predvidenih in nepredvidenih obrambnih potreb, in sicer s spremenljivo natančnostjo ali z naključjem pri predvidevanjü ${ }^{8}$.

Proučevanje Clausewitzevega dela O vojni (2004, str. 45) nas usmerja k ugotovitvi, da je s poudarjanjem izziva, ki ga predstavlja interakcija med vojskujočimi, zadel bistvo problema, s katerim se srečujejo obrambni planerji. Clausewitz (prav tam) pravi, da je: »vojna področje negotovosti; tri četrtine reči, na katerih temelji ukrepanje v vojni, so zavite v meglo bolj ali manj velike negotovosti $\ll^{9}$. Ta presoja se sicer zdi samoumevna, za nas pa je pomembno, da se posledice v procesu obrambnega

\footnotetext{
Ta kontekst je pripomogel, da so države in njeni obrambni resorji odločno prepoznali potrebo po prilagoditvi planiranja pogojem izrazite negotovosti ter vzpostavitvi obrambnih zmogljivosti, dovolj prožnih za soočenje z nepredvidljivo prihodnostjo. Pri pripravi razvojnih planskih dokumentov je bilo treba iz tradicionalnega pristopa, temelječega na enem scenariju ali več ozko opredeljenih scenarijih, preiti na večscenarijski (širok) pristop planiranja, ki omogoča večjo strateško in operativno prilagodljivost (Davis, 1994, str. 4). Takšen pristop planiranja temelji na planiranju zmogljivosti, pri katerem je zaradi spodbujanja raznolikosti in prilagodljivosti mogoče hitreje povečati in uporabiti različne vrste zmogljivosti v kriznih situacijah ter je kot tako veliko primernejše kot prejšnje, na grožnjah temelječe planiranje, v katerem je bila pozornost usmerjena na potek $s$ točno določeno grožnjo.

8 Tudi Benko (1997, str. 54) za razliko od deskripcije in pojasnjevanja pojavov izpostavlja prognoziranje kot pristop, za katerega ni mogoče trditi, da bi lahko zadovoljil zahteve znanosti, ko gre za napovedovanje, še zlasti za predvidevanje posebnih procesov in dogajanj v srednje- in dolgoročnem časovnem razponu. Problem prognoziranja in njegovih možnosti napovedovanja posebnih dogodkov še naprej ostaja nepremostljiva težava, ki je ni mogoče obvladati z uporabo modelov, vzorcev človekovega vedenja ter napovedovanjem individualnih in skupinskih pojavov. Zatekanje k splošnim pa po Benku (prav tam, str. 54) znižuje natančnost, kar je pripisati predvsem množici spremenljivk $v$ dogajanjih v nacionalnem in mednarodnem prostoru, ki jih ni mogoče obvladati s številčnim ovrednotenjem.

9 Clausewitz (2004, str. 42-60) torej jasno izpostavlja, da je vojna področje naključja, ki poveča negotovost vseh okoliščin in moti potek dogodkov. Ta negotovost in stalno vmešavanje naključij povzročata, da udeleženec $v$ vojni najde stvari vedno drugačne, kot jih je pričakoval. Zaradi spremenljivih okoliščin postanejo plani in $k$ planom pripadajoče predstave nerealni. Čeprav je vpliv na spremembe plana lahko zelo velik, pa se pogosto zgodi, da ni dovolj podatkov, na podlagi katerih bi lahko v določenem času prilagodili usmeritev ali odločitev.
} 
planiranja v praksi izkazujejo pri oblikovanju planskih produktov pod znamko »dovolj dobro«.

Pri tem ne gre za izmikanje neugodni realnosti, ki bi lahko imela kontradiktoren pomen za strategijo in funkcijo obrambnega planiranja. Med vojno se napake pri planiranju po navadi odkrijejo precej hitro zaradi nasprotnikovih dejanj, čeprav jih ni mogoče vedno natančno argumentirati. Pridobivanje povratnih informacij je v takšnih okoliščinah veliko bolj evidentno, saj se lahko prikazujejo s številom smrtnih žrtev. Ne glede na to, da je takšne napake mogoče prepoznati na podlagi povzročene škode, pa ni mogoče z gotovostjo izpostaviti vzroka za napake. Za razliko od pogojev, v katerih delujejo obrambni planerji med vojno, ko se neposredno srečujejo s posledicami nasprotnikovih demonstracij in svojih napak, se obrambni planerji v miru vedejo bolj ignorantsko do zmotnosti svojih izbir. Bistvo problema, ki ga poudarja tudi Gray (2014 b, str. 11), je neobstoj celovitih in zanesljivih podatkov o prihodnjih obrambnih potrebah. Če se negotovost razume kot zaviralec procesa obrambnega planiranja, se to zelo razločno prikazuje kot politično in strateško tveganje ${ }^{10}$. Zgodovinske izkušnje kažejo, da morajo zlasti države z demokratično ureditvijo imeti pred sabo resno grožnjo, ki se mora najprej pojaviti, šele potem bodo vanjo verjeli (Gray, 2014 b, str. 24). Po definiciji bi morali biti jutri pametnejši, kot smo bili danes ali včeraj. Kljub temu je to pravilo pri obrambnem planiranju težko razumno zagovarjati. Grožnje varnosti, ki si jih samo abstraktno predstavljamo in predvidevamo, v sedanjosti ne predstavljajo posebnih skrbi za davkoplačevalce.

\subsection{Sodobni vidiki obrambnega planiranja}

Planiranje je proces, usmerjen $\mathrm{v}$ razreševanje problemov z jasno opredeljenimi rezultati v okviru pogojev »ends «, »ways « in »means « $^{11}$. Usmerjeno je v iskanje povečevanja gotovosti $\mathrm{z}$ upoštevanjem vseh smiselnih spremenljivk v okolju, $\mathrm{z}$ določanjem vzorčno-posledičnih odnosov med njimi ter s povezovanjem »ends«, »ways« in »means«. Planiranje je lahko dolgoročno, srednjeročno ali kratkoročno. Dolgoročni plan, ki obsega 20-letno obdobje, ni neskladen z logiko planiranja, vse dokler ima planska organizacija relativno jasno vizijo prihodnosti in je sposobna predvideti probleme, ki jih lahko reši. Vendar brez strategije po Yargerju (2008, str. 10) ni mogoče celovito opredeliti dolgoročnih interesov na nacionalni ravni. S strategijo se lahko oceni okolje in se določijo cilji za uspeh ter povežejo »ends«, »ways« in »means«, ki bodo vodili k tem ciljem. Planiranje je pri tem omejeno $\mathrm{z}$ okvirjem strategije in usmerjeno v razreševanje problema $\mathrm{z}$ doseganjem strateških ciljev (»ends«) znotraj meja zmožnosti, ki jih zagotavljajo »ways« in »means«.

\footnotetext{
${ }_{10}$ Vojna je eno izmed področij negotovosti, ki vselej zahteva natančen in pronicljiv razum za ukrepanje, čeprav je zaradi stalnega vmešavanja naključij ta vedno pomanjkljiv. Dejavnike negotovosti in naključij Clausewitz izpostavlja tudi pri oblikovanju strategij in obrambnem planiranju, saj temeljita na predpostavkah, ki jih ni mogoče podrobno navesti brez poznavanja okoliščin. Zato Clausewitz poudarja potrebo po stalnem spremljanju njunega izvajanja tudi v praksi, v neposrednem stiku z okoljem, da bi se lahko tako določile manjkajoče podrobnosti oziroma izvedle prilagoditve (Clausewitz, 2004, str. 103-106).

${ }^{\prime \prime} Z$ »ends« (cilji) se pojasnjuje, »kaj« mora biti doseženo, z »ways« (strateškimi koncepti, postopki), »kako« morajo biti doseženi cilji z uporabo razpoložljivih virov, z »means « (viri) pa, katere specifične vire uporabiti pri konceptih za dosego ciljev (več o tem na primer v Yarger, 2006, Bartholomees, 2010, Vuk, 2016).
} 
Pojem obrambno planiranje je v literaturi različno opredeljen. Obrambno planiranje lahko v najširšem smislu opredelimo kot instrument za zagotavljanje obrambnih potreb države $\mathrm{v}$ kratkoročnem, srednjeročnem in dolgoročnem obdobju. Taka opredelitev obrambnega planiranja kot procesa obsega faze:

- pripravo planskih izhodišč, ki vključuje presojo varnostnega okolja (ogroženost, omejitve, napoved razvojev okolja), pregled delovanja obrambnega sistema, vizijo in poslanstvo obrambnega področja,

- določitev obrambnih zmogljivosti, nujnih za doseganje ravni nacionalnih ambicij na obrambnem področju, ob upoštevanju projekcije obrambnih virov ter nacionalnih obrambnih potreb in mednarodnih obveznosti,

- določanje splošnih (dolgoročnih) planskih ciljev za razvoj in vzpostavitev obrambnih zmogljivosti ter ugotavljanje planskih vrzeli, izbiro najboljših strategij,

- programiranje oziroma razporejanje razpoložljivih obrambnih virov,

- uresničevanje in nadzor nad uresničevanjem planov (prirejeno po Pučko v Možina (et al.), 2002, str. 272-273).

Za proces obrambnega planiranja sta pomembna tudi koordinacija s komplementarnimi socialnimi, ekonomskimi in politično-diplomatskimi ter drugimi programi in aktivnostmi, ter sodelovanje z zavezniki, partnerji in prijateljskimi državami (Gray, 2014 b, str. 4).

Tudi Davis (1994, 2007 a, 2007 b) opredeljuje obrambno planiranje generično, kot obliko strateškega planiranja, ki ob upoštevanju političnih ciljev in usmeritev strategije na podlagi predvidevanja ter opredeljevanja postavlja planske cilje in naloge obrambne prvine za plansko obdobje. Njegov namen je omogočiti dovolj dobro zagotovitev obrambnih potreb in pripravljenost obrambnih zmogljivosti na negotovo prihodnost $\mathrm{v}$ okviru finančnih in gospodarskih zmožnosti države. $\mathrm{Z}$ dinamičnega vidika ima obrambna organizacija nenehne težave s tem, kako porabiti omejene vire za doseganje temeljnih obrambnih ciljev. Prizadevanje obrambnega planiranja ne bi smelo biti usmerjeno zgolj v »prebijanje skozi izzive« in naivno pričakovanje napovedanega razvoja prihodnosti, temveč tudi $\mathrm{v}$ zagotavljanje prožnosti, prilagodljivosti in robustnosti (angl. FAR - flexibility, adaptiveness and robusteness) nacionalnih obrambnih zmogljivosti. Davis (prav tam) v svojih delih o sodobnem pomenu obrambnega planiranja ${ }^{12}$ še ugotavlja, da predstavlja rešitev za planiranje v pogojih negotovosti pravzaprav planiranje za prilagodljivost. Meni, da je ključ za planiranje pod pogoji negotovosti izbira takšnih strategij, ki so prožne,

\footnotetext{
${ }_{12}$ Konec hladne vojne je zahteval poleg drugih strateških sprememb v mednarodnih odnosih tudi temeljit pregled in spremembe obrambnega planiranja. Odprla so se vprašanja, ki vplivajo na glavne značilnosti in obseg vojaških zmogljivosti. Ta vprašanja ne vključujejo samo klasičnega vprašanja, »koliko je dovolj«, temveč tudi, kot pravi Davis (1994, str. 3), vprašanja o ciljih: kakšen obseg zmogljivosti potrebujemo glede na spremembe vojskovanja in raznolikosti morebitnega nasprotnika. Še pomembnejše vprašanje se nanaša na to, kako najbolje uporabiti razpoložljiva sredstva za obrambo. Planiranje, ki se bo na primer končalo danes, bo po najboljših močeh določilo zmogljivosti za naslednje desetletje, čeprav ni mogoče vedeti z gotovostjo, kakšen bo takrat svet.
} 
prilagodljive in robustne ${ }^{13}$. Prednost tako širokega razumevanja področja obrambe je po mnenju Graya (2014 b, str. 5) izbira. Izbire, narejene na področju obrambe, morajo biti izvedene $\mathrm{v}$ podporo idejam o prihodnji kvantitativni in kvalitativni nacionalni varnosti in zmeraj obsegajo več kot le vojaško komponento. Gray (prav tam) poudarja, da se skrb za obrambne zadeve kaže v trajni potrebi politične oblasti po planiranju oziroma sistematičnem zagotavljanju ukrepov zoper verjetne grožnje varnosti, ki vključujejo tudi grožnjo uporabe ali uporabo vojaške sile. Celotna politika je zavezana k reševanju izzivov obrambnega planiranja ter skrbi za prihodnjo varnost, ki lahko obsega tudi nevarnost v vojaški obliki. Gre za edinstvena pomen in vlogo obrambe v kontekstu varnosti, ki jo zasledimo v odnosih med politiko, strategijo in obrambnim planiranjem (glej sliko 1). Pogoste navidezne konkurenčne opredelitve obrambnega planiranja, ki jih lahko najdemo v okolju, nas ne bi smele odvrniti od veliko večjega pomena obrambnega planiranja ter njegove vloge pri zagotavljanju varnosti.

Slika 1: Povezanost politike, strategije in obrambnega planiranja Vir: povzeto po Gray, 2014 b, str. 24.

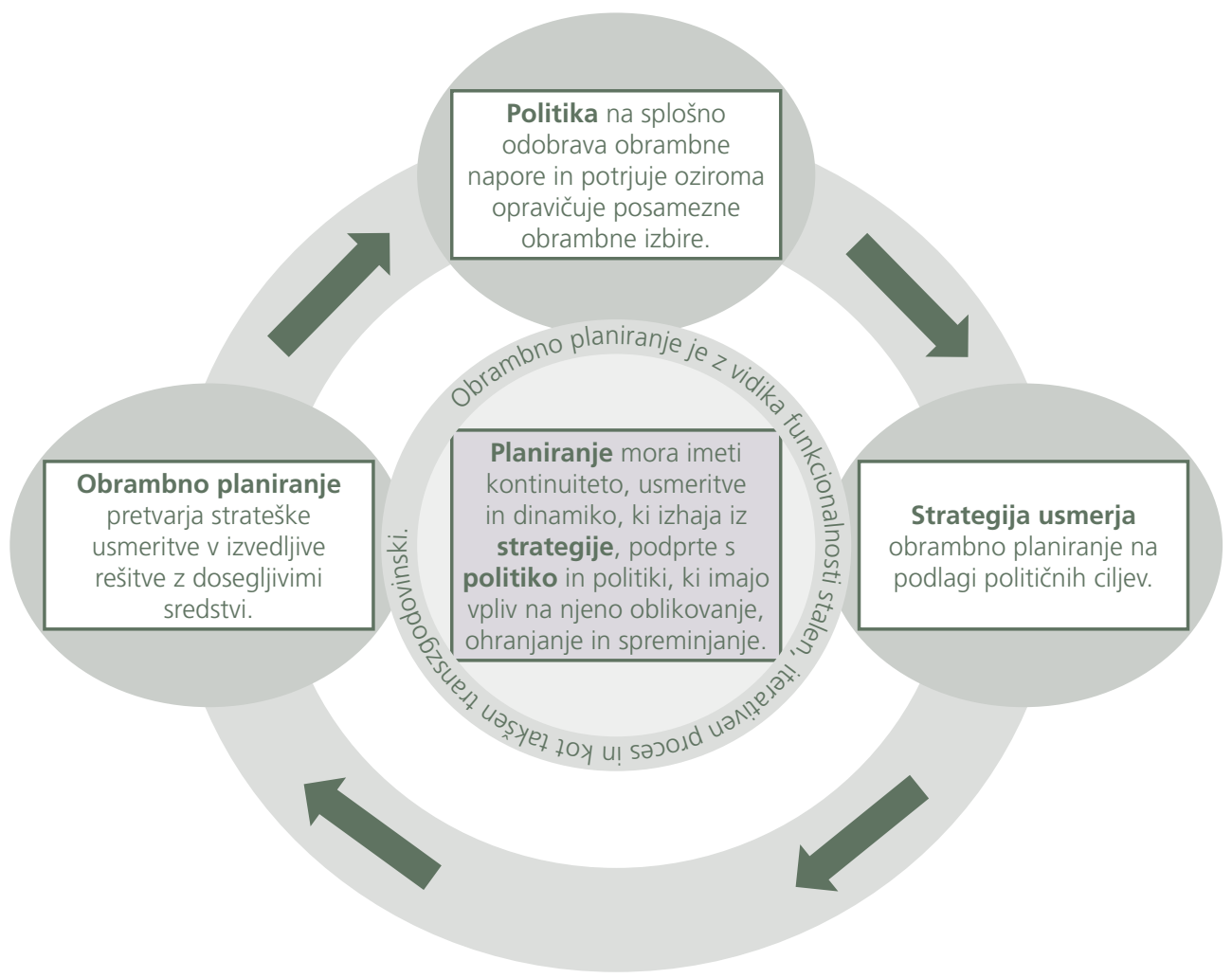

${ }_{13}$ Prožnost pri tem razume kot sposobnost soočenja z novimi nalogami in izzivi, prilagodljivost povezuje s sposobnostjo spoprijemanja s spremenljivimi okoliščinami, robustnost pa pomeni sposobnost vzdržnega odzivanja na varnostna tveganja in grožnje ter okrevanja od negativnih pretresov (Davis (prav tam)). 
Planiranje ima neposreden odnos s politiko tudi v kontekstu reševanja pomembnih vprašanj, ki so vedno predstavljena kot prednostna pri reševanju problemov. Interes (pritisk) politike je, da se takšna vprašanja rešujejo z že veljavnimi plani ali v obliki posebne naloge, ki je podprta z ustreznim planiranjem. Zaradi pomembnosti vprašanj se lahko zahteva pospešitev njihovega reševanja, kar pa ni nujno skladno s strategijo, planom ali politiko pristojnega organa, na katerega se takšno vprašanje nanaša. Če strategija in iz nje izhajajoči plan že obstajata in bi se zaradi prednostnega reševanja takšnega problema zgodilo neskladje, bi bilo smiselno, kot pravi Yarger (2008, str. 11), na vladni ravni izvesti krizni načrt zaradi spremenjenih notranjih in zunanjih okoliščin, ki morajo biti ponovno ocenjene v neposrednem sodobnem kontekstu, še preden se izvedejo ukrepi. Glede na realnost okolja se morajo posledično prilagoditi in ustrezno dopolniti tudi vse obstoječe strategije in plani. Planerji morajo razumeti teorijo strategije in strateško razmišljanje, da bi lahko uresničevali politiko in strategijo. Prav tako morajo razumeti implikacije planskih odločitev za širše politične cilje in strategije, ko izvajajo takšno krizno načrtovanje ali ko neposredno planirajo rešitev političnega vprašanja ${ }^{14}$.

Funkcija obrambnega planiranja je za politike ves čas nujna, čeprav z različno intenzivnostjo $\mathrm{v}$ različnih obdobjih. Nasprotnik s predvidljivim dolgoročnim vplivom sicer bistveno olajša naloge obrambnih planerjev, vendar lahko po drugi strani ravno to zmanjša planerjevo ostrino, s tem ko ohranja predpostavke o verjetnih vojaških izzivih $\mathrm{v}$ prihodnosti, ki jih ni mogoče dovolj hitro prilagoditi spremenjenim okoliščinam (Gray, 2014 b, str. 25). Zlato pravilo za kompetentno obrambno planiranje bi moralo biti tisto, ki kot dejstvo sprejema negotovost domače in zunanje politike ter tudi morebitne odklone strategije. Obrambno planiranje ima zmeraj politični kontekst, njegova vsebina pa ne more biti ustrezno cenjena, če je ta kontekst zapostavljen.

Upoštevanje zlatega pravila v obrambnem planiranju po načelu »dovolj dobro« je sicer primerno za soočenje z negotovostjo politike in strategije, vendar še vedno ostaja vprašanje, kaj to pomeni v praksi. Gray (2014 b, str. 40) pravi, da sta za dolgotrajne krizne situacije ali vojne vnaprejšnje posedovanje zmogljivosti in pripravljenost edini primerni merili za »dovolj dobro $\ll^{15}$ kot najboljši način za ohranitev miru ter stabilnosti v sodobnem mednarodnem in nacionalnem varnostnem okolju.

\footnotetext{
${ }_{14} \check{C}$ e je politika pravilna in se uresničuje zastavljeni cilj, to ugodno vpliva na uresničevanje strategije in obrambnega planiranja. V nasprotnem primeru je treba iskati izvor v napačni politiki (glej tudi Clausewitz, 2004, str. 289). Odnos med politiko, strategijo in obrambnim planiranjem je v vsebinskem smislu izrazito hierarhičen in odvisen predvsem od »zdrave" politike.

${ }^{15}$ Dober primer pomena predhodnega obrambnega planiranja (angl. pre-war defence planning) je tudi britansko jedrsko zastraševanje štirih jedrskih podmornic razreda vanguard, oboroženih z balističnimi raketami. Podmornice niso namenjene toliko za delovanje proti neznani ali celo trenutno kredibilni predvideni strateški nujnosti, kot pa predstavljajo ukrep zavarovanja proti najslabšemu mogočemu scenariju, ki bi se lahko zgodil v britanskem zunanjem varnostnem okolju $v$ prihodnosti.
} 


\section{OBRAMBNO PLANIRANJE MED POLITIKO IN STRATEGIJO}

Politika, strategija in obrambno planiranje ne predstavljajo treh ločenih aktivnosti, čeprav opravlja vsaka zase svojo temeljno funkcijo in se med sabo razlikujejo. Obrambno planiranje uporablja strategijo, zato da uresničuje politiko, kar je v bistvu tudi njegov namen. Clausewitz (2004, str. 285-292) je trdil, da vojne ni mogoče ločiti od političnega življenja, ker bi postala nesmiselna. Politika države, ki se večinoma obravnava kot organizirana celota številnih dejavnosti, zmeraj predstavlja najvišje stališče, iz katerega izhajata tako strategija kot obrambno planiranje. Le na takšen celovit in skladen način postane, kot pravi Clausewitz (prav tam), dojemanje in presojanje lažje, prepričanje močnejše, motivi zadovoljivejši in zgodovina razumljivejša. Zato je pomembno poznati medsebojno odvisnost med politiko, strategijo in obrambnim planiranjem, brez katere obrambno planiranje ne more biti uspešno (glej sliko 2). Politika in strategija nista moteča vira obrambnega planiranja kot permanentne funkcije in procesa vlade, temveč predstavljata nujen integralni in vitalni del tega procesa (Gray, 2014 b, str. 26).

Slika 2:

Prekrivanje štirih konceptov in njihov pomen Vir: povzeto po Gray, 2014 b, str. 11.

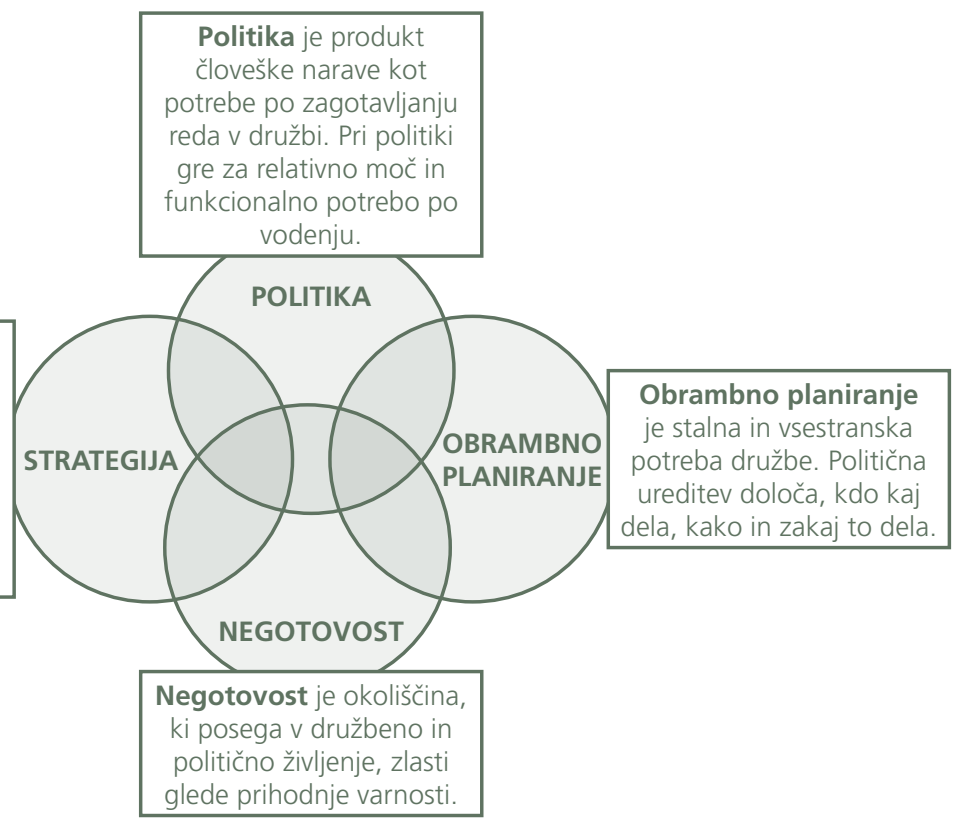

Pomen in razumevanje vloge obrambnega planiranja $v$ sistemu nacionalne varnosti ter njegov odnos do politike in strategije se v znanstvenih in raziskovalnih študijah bistveno ne razlikujejo. Glavna razlika med intelektualnimi deli (glej npr. Yarger, 2008, Gray, 2014 b, Murray, W., Hart, Sinnreich, R., Lacey, J. (ed.), 2011, Murray, W., Knox McGregor, Bernstein A. (ed), 1994) je obravnavanje njegove funkcije. 
Yarger (2008, str, 51-52) trdi, da strategija ni planiranje in da tudi planiranje ni strategija. Planiranje se razlikuje v miselnosti, saj je njegov namen, da uresničuje strategijo. Opira se na visoko stopnjo gotovosti - na svet, ki je konkreten in se lahko obravnava nedvoumno. V bistvu siva področja sveta, na podlagi analiz dejstev in predpostavk o nepoznanem, predstavi v črnem in belem. Planiranje je pravzaprav linearno in determinativno ${ }^{16}$, osredotočeno na najpomembnejše vzroke in učinke. Predpostavlja, da so lahko prihodnji rezultati natančno znani, če je dovolj znanega glede dejstev in pogojev, ki vplivajo na družbeni sistem. Proces planiranja je pomemben za zmanjševanje negotovosti na operativni in taktični ravni, saj omogoča predpisovanje podrobnih ukrepov. Planiranje je bistveno za uspešno uresničevanje strategije. Večina strokovnjakov s področja nacionalne varnosti je usposobljena za planiranje v razmerah gotovosti, medtem ko je njihova dojemljivost za negotovost, ki je prav tako del strateškega področja, izrazito šibka.

Slika 3:

Deset temeljnih razlik med strategijo in obrambnim planiranjem

Vir: povzeto po Yarger, 2008, str. $38-53^{17}$.

\begin{tabular}{|c|c|}
\hline 1 & $\begin{array}{l}\text { Strateg mora razumeti razliko med strategijo in obrambnim planiranjem, da bi lahko pripravil dobro } \\
\text { strategijo. }\end{array}$ \\
\hline 2 & $\begin{array}{l}\text { Obrambni planer mora razumeti razliko med obrambnim planiranjem in strategijo za uspešno } \\
\text { uresničevanje strategije. }\end{array}$ \\
\hline 3 & Obrambni planer je v svojem pristopu sistematičen, nazoren strateg pa je bolj splošen. \\
\hline 4 & Obrambno planiranje premosti vrzel med strategijo in izvedbo. \\
\hline 5 & $\begin{array}{l}\text { Namen strategije je razjasniti, vplivati, upravljati in razreševati nestabilnost, negotovost, } \\
\text { kompleksnost in dvoumnost (angl. VUCA) strateškega okolja z identifikacijo in ustvarjanjem } \\
\text { strateških učinkov v podporo političnim ciljem. }\end{array}$ \\
\hline 6 & $\begin{array}{l}\text { Namen obrambnega planiranja je zagotavljanje obrambne sposobnosti za nemoten razvoj in } \\
\text { delovanje družbe ter njenih institucij in organizacij. }\end{array}$ \\
\hline 7 & $\begin{array}{l}\text { Strategija opredeljuje, kaj je pomembno in dosegljivo, parametre za odzivanja (ukrepe) ter splošen } \\
\text { okvir virov, ki jih je država pripravljena zagotavljati. }\end{array}$ \\
\hline 8 & $\begin{array}{l}\text { Strategija s svojo hierarhično naravo opredeli cilje, ki jih je treba doseči, in okvir za obrambno } \\
\text { planiranje (omeji obrambno planiranje). }\end{array}$ \\
\hline 9 & $\begin{array}{l}\text { Obrambno planiranje znotraj tega okvira prilagaja strategijo konkretnim okoliščinam v okolju z } \\
\text { dejstvi, podatki in na izračunih temelječimi medsebojnimi povezavami ter zaporednimi ukrepi } \\
\text { (programiranje) za doseganje ciljev strategije. }\end{array}$ \\
\hline 10 & Strategija in obrambno planiranje si delita paradigmo "ends", "ways" in "means". \\
\hline
\end{tabular}

\footnotetext{
${ }^{16}$ Pojem linearno razumemo v obrambnem planiranju $v$ smislu terminskega planiranja longitudinalnih dejavnosti, pri katerih se isti procesi ponavljajo. Plani, ki izhajajo iz takšnega procesa, med drugim omogočajo učinkovito primerjavo med planirano in izvedeno realizacijo vzpostavitve na primer zmogljivosti (več o linearnem planiranju npr. Harmelink, D., J., 2001). Determinirati pa v planiranju pomeni, da se cilji in predvidene aktivnosti določijo oziroma opredelijo vnaprej.

${ }^{17}$ Kratica VUCA pomeni v angleškem besednjaku - volatility, uncertainty, complexity and ambiguity.
} 
Yargerjev pogled je jasen in smiseln, hkrati pa ne zavzema preveč ostre kategorizacije. Gray (2014 b) je v svojih spoznanjih o obrambnem planiranju veliko prodornejši in pronicljivejši raziskovalec. V svojem delu dokazuje, da bi moralo biti obrambno planiranje v smislu natančnosti in uporabnosti obravnavano kot funkcija, ki bi morala doseči združitev strategije in planiranja. Združitev pri tem razume bolj v smislu pripravljenosti po skupnem »zagovarjanju « domnevne prihodnosti kot pa to, da so plani dovolj dobro pripravljeni in ustrezajo izbrani strategiji v prihodnosti. Gray izpostavlja, da ta perspektiva nikakor ne posega $\mathrm{v}$ degradacijo bistva planov, ki morajo biti zaradi svoje učinkovite uresničitve jasni in natančni. Zagovarja bolj inkluzivno razumevanje strategije, kot je običajno. Po njegovem mnenju je za strateško delovanje škodljivo, da lahko samo strategi ustvarjajo in usmerjajo izvajanje strategije, planerji pa pripravljajo zgolj plane, namenjene za dosego ciljev in nalog, z natančnimi navodili za operativne poveljnike in njihove taktične enote. Ta konceptualna zgradba seveda ni povsem napačna, vendar po razumevanju Graya ogroža celovitost bistva razumevanja strategije in obrambnega planiranja.

Za strategije lahko rečemo, da so domnevna razlaga tega, kako bi morali biti doseženi želeni učinki na podlagi zaznanih virov ogrožanja ter $\mathrm{v}$ kakšnem zaporedju bi morali biti udejanjeni. Strateško gledanje na razvoj sveta in njegov spremljajoči zakon entropije nam dajeta spoznanje, da svet sam po sebi ne spodbuja in ne daje urejenih kategorij, ki bi se lahko preprosto uporabile v »poljudni« predstavitvi. Tako kot politika ni izključno samo nacionalna ali mednarodna ter vojne in vojskovanja ne morejo biti strogo razmejeni na regularne in neregularne vrste, tudi strategije ne morejo biti izključno ofenzivne ali defenzivne. Sestavine strategije (»ends«, »ways« in »means«) so v praksi med sabo tako povezane, da vztrajanje na njihovi konceptualni jasnosti in razmejenosti ogroža razumevanje njene celovitosti. Sodobno razumevanje koncepta strategije kot vodilnega usmerjevalnega koncepta nacionalne varnosti poudarja celovitost obravnavanja nacionalne varnosti. $V$ tej celovitosti pa morajo biti prepoznane vse njene glavne sestavine (na primer diplomacija, politika, ekonomija, obveščevalna dejavnost, obrambne zmogljivosti), ki so nujne tudi za obrambno planiranje. Zanimivo je, da so se v zgodovini zamisli, načrti in poskusi udejanjanja strategije v praksi le redko upoštevali kot pravilo (Gray, 2014 b, str. 31). Tudi Murray (v Gray, 2014 b, str. 31) ugotavlja, da je v preteklosti strateški okvir, še manj pa strategija, redko predstavljal vodilo za tiste, ki so bili odgovorni za dolgoročno preživetje države tako v političnem kot v vojaškem smislu.

Glavna razloga za to redkost sta kompleksnost strategije po eni strani ter njeni realnost in relevantnost ob nepredvidenih naključjih po drugi strani. Zgodovinske izkušnje kažejo, da se politika najpogosteje odzove takrat, ko so dogodki aktualni 
ali neizbežni, kar se vidi kot mandatno dejanje ${ }^{18}$. Gray (2014 b, str. 31) to zgodovinsko realnost izpostavi še bolj radikalno, in sicer, da »politika v realnih situacijah pogosto zavrača možnosti racionalne izbire, ki jo ponuja strategija«. Veliko prepričljivejšo vlogo pri strateški izbiri imajo po njegovem mnenju kultura, navade ter tradicija, ki sicer omogočajo izbiro, vendar ob bistveno manjšem naporu, ki ga povrh usmerja še zakon inercije. Tudi Clausewitz (189, str. 154) je opozoril na ta fenomen in izpostavil, da bodo, dokler ne bo obstajala sprejemljiva teorija o vodenju vojne, rutinske metode tiste, ki jih bodo uporabljali tudi na najvišji ravni.

Pri odločanju gre torej za proces razreševanja problemov in sprejemanja odločitev o izbrani rešitvi (izbiri). Odločitve so lahko strukturirane ali nestrukturirane. Strukturirane odločitve je mogoče programirati, so napovedljive, se ponavljajo, informiranje je zanesljivo. Takšno odločanje pogosto poteka po vodilih in pravilih vedenja. Nestrukturirane odločitve so enkratne, ustvarjalne, negotove (nezanesljive) in $\mathrm{z}$ nepredvidljivimi posledicami, zato se je treba odločati na podlagi presoj in intuicij ${ }^{19}$. Te se nanašajo na strateško določanje in strategije, ki obsegajo strateške cilje, ki so zelo pomembni ter povezani z velikimi spremembami. Raven tveganja pri odločanju je odvisna od zadostne in kakovostne informacije, ki je obratno sorazmerna količini informacij. Povečanje količine in kakovosti informacij izboljšuje uspešnost odločanja in zmanjšuje tveganja, kar pa po drugi strani zahteva porabo virov (stroški, čas ipd.). Racionalno odločanje je tako mogoče le v popolni gotovosti, medtem ko je v popolni negotovosti odločanje prepuščeno zgolj ugibanju (Kralj v Možina (et al.), 2002, str. 346-353, Tavčar, 2005, str. 7).

Veliko državnih akterjev $\mathrm{v}$ praksi zamenjuje strategijo in obrambno planiranje. Posledica tega je, da je planska raven razmišljanja pogosto uporabljena v strateškem razvojnem procesu oziroma da so planski cilji in koncepti povzdignjeni na strateško raven. Čeprav je lahko plan učinkovit, v takšnem primeru nastali strateški učinki ne morejo biti ustrezno podprti oziroma so kontraproduktivni glede na politične cilje ali druge interese (več o tem Yarger, 2008, str. 38-53). Politiki, državni uradniki, vojaki, ki jim strateško razmišljanje ni tuje, lahko ta spoznanja uporabijo kot intelektualni opomnik v zvezi z njihovo odgovornostjo do nacionalne varnosti.

\footnotetext{
${ }_{18}$ Kot očiten primer takšnega ravnanja lahko izpostavimo Britanijo v obdobju med prvo in drugo svetovno vojno, ko je na pobudo Winstona Churchilla, nekdanjega poveljnika admiralitete in ministra za kopensko vojsko in letalstvo, sprejela načelo: "Z namenom, da določimo okvir obrambnih ocen, moramo predpostavljati, da $v$ nekem danem trenutku velja, da vsaj deset let ne bo nobene večje vojne." To pravilo »desetih let« so nato obnavljali vsako leto znova in vse do leta 1937 Britanija ni sprejela nobenih večjih ukrepov za ponovno oborožitev, čeprav je že leta 1933 v Nemčiji prevzel oblast Hitler, ki je zelo očitno spreminjal izid prve svetovne vojne (več o tem Keegan, 2005, str. 490-499).

${ }_{19}$ Raziskave kažejo, da je na najvišji odločevalski ravni okrog 80 \% intuitivnega odločanja, 16 \% analiznega (zasnovano na proučenih informacijah) ter $4 \%$ rutinskega (ponavljajočega se) odločanja, na izvajalski ravni pa $2 \%$ intuitivnega, $35 \%$ analiznega ter $63 \%$ rutinskega odločanja. Raba intuicije je glede na raziskave najkoristnejša pri oblikovanju odločitev, če je veliko negotovosti, premalo izkušenj, ni zanesljivih dejstev, če je čas zelo omejen in so zahteve po pravilni razrešitvi velike in če je več sprejemljivih različic, ki se zdijo razumne (več o tem glej Kralj v Možina (in drugi), 2002, str. 363-365). Ker gre intuicija pogosto čez rob razumnega in stvarnega, je znanost ne potrjuje v celoti. Kljub temu deluje tvorno, posebno takrat, ko odločevalci verjamejo $v$ njeno delovanje. Te ugotovitve vodijo $k$ sklepu, da je za učinkovito odločanje smotrno razvijati tudi intuitivne spretnosti.
} 


\section{NOVO ZNANJE ZA SODOBNE OBRAMBNE PLANERJE}

Obrambni planerji morajo biti pozorni na sodobne varnostne kontekste v svetu, ki so edini vir za identificiranje in zagotavljanje nujnih obrambnih zmogljivosti za prihodnost. Težava, ki je ni mogoče natančno nasloviti, je povezana s časom in negotovostjo. Gray (2014 b, str. 38) ugotavlja, da obrambni planerji kljub znanju in izkušnjam pogosto zanemarjajo intuicijo, s katero se največkrat predvidi potek prihodnje zgodovine, ki pa zaradi premalo znanih zanesljivih dejstev ne more biti opredeljena s koledarsko natančnostjo.

Zgodovinske izkušnje predstavljajo pomemben vir za teorijo obrambnega planiranja, ne dajejo pa nobene prave alternative za oblikovanje planov, pripravljenih za prihodnost. Gray (2014 b, str. 38) izpostavlja vprašanje objektivnosti in omejitev zgodovinarjev, ki jih je treba razumeti bolj v smislu francoskega izreka »faute de mieux ${ }^{20}{ }^{2}$. Problem zatekanja k zgodovinskim virom nastane takrat, ko se dognanja, ki predstavljajo zgolj pojasnjevalne dokaze in so kot takšna nujna za razvoj teorije, smiselno ne prilagodijo sodobnim okoliščinam delovanja obrambnega planiranja. Zagotovo smo lahko zaskrbljeni, če se izvaja obrambno planiranje na podlagi šibkega zgodovinskega razumevanja, kot smo lahko zaskrbljeni tudi, če so zgodovinski viri narobe, dvomljivo in nejasno uporabljeni. Te ugotovitve zahtevajo potrebo po naprednem izobraževanju obrambnih planerjev, ki vključuje tudi proučevanje zgodovine. Poleg izobrazbe obrambnega planerja je treba upoštevati še kontekst časa, prostora in kulture, ki se nanaša na preteklost in njegovo individualno dojemanje prihodnosti.

Planiranje prihodnosti se izvede s programiranjem znotraj danih možnosti, kar v praksi pomeni, da je treba obrambne priprave izvajati tako, da so prilagodljive okoliščinam. Zato plani ne smejo biti preveč podrobno opredeljeni niti ne bi smeli predvidevati izoblikovanih možnosti za negotovo prihodnost. Pri tem je treba zaradi enotnejšega razumevanja poudariti temeljno razlikovanje in odnos med obrambnim planiranjem in obrambnim programiranjem, ki se v praksi, kot pravi Kotnik (2017), pogosto kar enači, nekateri pa niti ne priznavajo razlike med obema. Kotnik (prav tam) meni, da planiranje negotove srednje- in dolgoročne obrambne prihodnosti lahko konkretiziramo predvsem s kratkoročnejšim obrambnim programiranjem. Z obrambnim planiranjem torej specificiramo zahtevane »outpute« na obrambnem področju na strateški ravni kot tudi makroalokacijo planiranih obrambnih virov za obrambo v daljšem časovnem obdobju. Obrambno programiranje pri tem razumemo kot nadaljnje in natančnejše opredeljevanje ter strukturiranje aktivnosti ali korakov v obliki ciljev kot tudi že zelo natančno programirano alokacijo obrambnih virov za izvedbo »outputov«, ki vodijo do uresničitve plana in ki strategijo spreminjajo $\mathrm{v}$ akcijsko naravnanost. Uresničitev programskih ciljev je za razliko od plana opredeljena po letih in je povezana s točno določenim časovnim obdobjem. Obrambno programiranje v končni stopnji zagotavlja izhodišče za (naj)podrobnejšo

${ }^{20}$ V prevodu pomeni francoski izrek »če ni nič boljšega, v sili«. 
razčlembo obrambnega proračuna do najnižje ravni planiranja. Zato mora biti ustrezno prevedeno tudi $\mathrm{v}$ poslovne (izvedbene, kratkoročne) plane oziroma programe, kar bi bilo po Kotniku (prav tam) ustreznejše poimenovanje, pri katerem se določene aktivnosti za doseganje teh ciljev specificirajo in natančno (predvsem finančno) ovrednotijo, skladno z zahtevami »inputov« (več o tem tudi npr. Le Roux, 2002, 5-8). Gray (2014 b, str. 7) poudarja, da prihodnja varnost, v kontekstu nacionalne varnosti in obrambnega planiranja, predstavlja vedno nepredvidljivega talca odločitev, sprejetih danes za danes in za prihodnost. Tako kot obrambni planerji ne morejo vedeti nečesa, kar ni poznano vnaprej, je povsem jasno tudi, da se mora ključni izziv, ki si ga obrambni planerji prizadevajo dovolj dobro izpolniti, soočati s posledicami planskih napak. Zato so si številni avtorji enotni (na primer: Yarger, 2008, Gray, 2010, Davis, 2007, Murray, 1994), da obrambni planerji potrebujejo strategijo, ki jih bo zavarovala pred nepredvidenimi tveganji in dogodki, še posebno takšnimi, ki bi jih lahko nasprotnik v prihodnosti izkoristil. Kotnik (prav tam) ob tem meni, da je strategija samo nujen, ne pa hkrati tudi zadosten, pogoj za zmanjševanje tveganj, kajti brez vizionarskih, ambicioznih in preudarnih politikov je tudi najboljša strategija samo mrtva črka na papirju.

Ne glede na to, kakšno metodologijo uporabljamo, je sledenje kvantitativnim znanstvenim dokazom glede priprav za prihodnjo obrambo slepilno. Znanost ne more zagotoviti metode $\mathrm{z}$ neposredno koristjo, ki bi pomagala strateškim presojam, kot tudi ne more dati garancije za taktični uspeh s sredstvi in tehnologijo, ki naj bi prinesla zmago. Zaradi zmeraj prisotnih nacionalnih omejitev pa ni mogoče ustrezno zavarovati strategije z obrambnimi pripravami. Kontekst obrambnega planiranja v miru ne bi smel biti prepuščen zgolj izbiri kot zadnjemu sredstvu, temveč bi moral temeljiti na še izvedljivih izbirah (Gray, 2014 b, str. 41). Zato je za državo zelo pomembno, da zna delovati strateško in tako zmanjšuje naključja ter nevarnosti virov groženj, ki bi lahko ogrožale njene življenjske in strateške interese.

Sklep Clausewitz poudarja, da ima vojna politični namen. Tudi obrambno planiranje se nanaša na politiko, saj je tesno povezano z vojaško dejavnostjo. Politika je neprenosljivo človeška in se nanaša na vpliv ali relativno moč. Iz tega lahko sklepamo, da je obrambno planiranje prizadevanje človeka; je odgovor na prihodnjo relativno politično moč, zato mora biti razumljeno v smislu politike in njene narave. Ko poudarjamo politično dimenzijo strategije in njenega obrambnega planiranja, je vredno sprejeti določeno strateško tveganje, ki pa mora voditi k doseganju predvidenih političnih ciljev. Pri tem ne smemo mešati politike s strategijo, temveč je treba upoštevati konceptualno distanco med političnimi cilji (ends - »kaj«) in strateškimi koncepti (ways - »kako«). Strategija določa smer in uporabo vseh sredstev države, vključno z njenim vojaškim instrumentom, za namene politike, kot so jo določili politiki, in bi morala biti razumljena kot izračunano razmerje sredstev za doseganje političnih ciljev. Obseg političnih ciljev pa ni vedno povezan z velikostjo in strateško težo države. 
Preprosto, a varljivo vprašanje »koliko je dovolj«, odpira pomembna vprašanja, ki so vse prej kot preprosta. Eno izmed njih, ki pravzaprav predstavlja logično izhodišče za začetek analitičnega dela, se dotika vprašanja »dovolj za kaj«. Da bi razumeli izziv, ki ga predstavlja negotovost $\mathrm{v}$ povezavi z ignoriranjem določenih možnosti in ki nenehno preži na oblikovalce ter akterje v obrambnem planiranju, si je treba prizadevati za obvladovanje logične strukture in pragmatične realnosti strategije.

Osrednji izziv obrambnega planiranja je, kot smo ugotovili v prispevku, biti dovolj natančen $\mathrm{v}$ zadevi, ki se lahko izkaže kot pomembna za prihodnost nacionalne varnosti. Za planerja ni preprostega odgovora na vprašanje, kaj bi lahko bilo dovolj dobro. Razlog za neodločnost je prav dejstvo, da zadeva ni znana tako jasno, kot bi morala biti. Koristen vir pomoči za vse, ki usmerjajo razvoj obrambnega planiranja, so lahko, kljub svoji nenatančnosti in spornosti, pretekla spoznanja. Vedeti je treba, da se veliko podatkov neposredno prenaša na obrambno planiranje v obliki številčnih podatkov (na primer kadrovska struktura, nakup opreme in oborožitve, finančni podatki), ki imajo zelo pomirjevalno in navidezno zelo natančno sporočilno vrednost, sklicevanje nanje pa sproža zaupanje in razumevanje, kar lahko zasenči resnično negotovost.

Zaradi številnih spremenljivk (tudi nevednosti), ki so prisotne $\mathrm{v}$ obrambnem planiranju, je razumljivo, da iz planov ni mogoče jasno razbrati, kdaj, kje in proti komu bodo takšni plani nujni, kako bodo planirani viri uporabljeni za bojevanje in kakšna bo, kot pravi Clausewitz, »gramatika« prihodnjega bojevanja. Delo obrambnega planerja ni nikoli (do)končano, saj je planski proces nenehno podvržen dinamiki in spremenljivosti varnostnih okoliščin, ki vplivajo na učinkovitost obrambnega planiranja. S temi ugotovitvami lahko potrdimo v uvodu postavljeno tezo, da ni mogoče pripraviti niti absolutnega planskega izdelka niti oblikovati takšnega obrambnega proračuna, ki bo omogočal zadostna sredstva za »pravi« odziv na prihodnje varnostne grožnje in tveganja za nacionalno varnost. Čeprav je težko opredeliti »pravi« odziv, pa je, kot pojasnjuje Kotnik (2017), nekoliko lažje opredeliti (čeprav nikoli v popolnosti), kolikšno tveganje izhaja iz nekega »pravega« odziva, ki pa je vedno izključno breme politike in ne obrambnega planiranja. Pri tem ne govorimo o tveganju pojavitve napak pri planiranju, ki se jim nikoli ni mogoče v celoti izogniti, temveč o tveganju neskladja med nujnimi viri, ki so jih določili planerji za dosego želenega cilja, in viri, ki jih je določila politika. Hkrati pa smo ugotovili, da nas prav takšna negotovost prihodnjega varnostnega okolja usmerja in sili v stanje stalne dejavnosti na področju obrambnega planiranja, z namenom, da bi lahko vedno izkoristili najboljšo mogočo izbiro pri odločanju. Politika države bi si morala zavestno prizadevati za takšno izbiro, saj je od nje zelo odvisna tudi kakovost življenja državljanov. Kompleksno, soodvisno, nepredvidljivo in spremenljivo mednarodno varnostno okolje danes ne pušča politiki držav veliko manevrskega prostora za omahovanje ali celo ignoriranje varnostih groženj in tveganj.

Ko govorimo o prihodnjih obrambnih potrebah države, bi moralo biti osrednje vprašanje politike, z vidika omejenih ekonomskih zmožnosti, vselej usmerjeno na 
obrambno planiranje. Zanimati bi jo moral predvsem odgovor na temeljno vprašanje, ali bo imel predlagani plan dovolj dobre odgovore za prihodnje nacionalne obrambne potrebe. Odgovor je povezan s sklopom sedmih vprašanj. Njihovo utemeljevanje lahko v spremenljivih varnostnih okoliščinah močno vpliva na oblikovanje nacionalnovarnostne in obrambne politike, kar se kaže tako v strategijah kot $\mathrm{v}$ obrambnem planiranju. Po Grayu (2014 b) gre za sklop vprašanj:

1. kako daleč $\mathrm{v}$ prihodnost nas mora resno skrbeti;

2. kdo ali kaj lahko vpliva na občutek (ne)varnosti v prihodnosti;

3. koliko varnosti potrebujemo oziroma si je lahko privoščimo in uresničimo z obrambnim planiranjem;

4. kakšen bo značaj prihodnjega varnostnega okolja;

5. s kakšnimi konflikti, vojnami in vojskovanjem se bomo spopadali v prihodnosti;

6. kako sposobne bodo morale biti $\mathrm{v}$ prihodnosti nacionalne oborožene sile količinsko in kakovostno;

7. kako prepričani bi morali biti, da bodo nacionalne oborožene sile taktično, strateško in tudi politično učinkovite, glede na to, da imata vsak konflikt in vsaka vojna svoj način vojskovanja oziroma svojstven značaj.

Ali se pri oblikovanju nacionalnovarnostne in obrambne politike, ki zahteva poseben odnos med politiko, strategijo in obrambnim planiranjem, v Republiki Sloveniji srečujemo s temi na videz preprostimi, a v resnici zelo kompleksnimi vprašanji? Če je namen politike pridobiti relevantne odgovore na postavljena vprašanja, bo tudi uresničevanje obrambnih ciljev veliko učinkovitejše pri zagotavljanju obrambnih potreb države.

In končno še odgovor na sklepno vprašanje: kdo sploh je obrambni planer? Obrambni planer v procesu obrambnega planiranja prevaja strategijo v prakso. Kot strateški teoretik v praksi s plani predlaga variantne rešitve za uravnotežen razvoj obrambnih zmogljivosti, nujnih za »dovolj dobro« zagotavljanje nacionalne varnosti. Predlagane rešitve v naslednjem koraku presoja politika, izbira po njenem mnenju najprimernejše in jih izvaja ter tako omogoča doseganje strateških ciljev. Gre za zahteven strokovni izziv obrambnih planerjev, ki je ob obvladovanju veščine planiranja povezan še z napornim delom in intuicijo, improvizacijo ter svojo kreativnostjo planerjev, saj v procesu obrambnega planiranja ni mogoče predvideti vseh situacij in odgovoriti na vsa vprašanja.

Literatura

1. Bartholomees, J., B. (ur.) (2010). Theory of War and Strategy (volume 1). The U.S. Army War College Guide to National Security Issues, Carlisle. Dosegljivo na spletu: www. StrategicStudiesInstitute.army.mil (22. 12. 2016).

2. Benko, V. (1997). Zgodovina mednarodnih odnosov. Znanstveno in publicistično središče, zbirka Sophia, Ljubljana.

3. Benko, V. (1997). Znanost o mednarodnih odnosih. Fakulteta za družbene vede, Knjižna zbirka Mednarodni odnosi, Ljubljana.

4. Brodie, B. (1959). Strategy in the Missile Age. RAND Corporation, Princeton University Press, Princeton, New Jersey. 
5. Carl von Clausewitz (2004). O vojni. Studia Humanitatis, Ljubljana.

6. Creveld M. (1977). Supplying War: Logistic form Wallenstain to Patton. Cambridge University Press, Cambridge.

7. Davis K., P. (1994). New Challenges for Defence Planning: Rethinking How much is enough. RAND, Santa Monica, California. Dosegljivo na spletu: www.rand.org/content/ dam/rand/pubs/monograph_reports/2007/MR400part1.pdf (19. 11. 2016).

8. Davis K., P. (2007 a). Lessons from Defense Planning and Analysis for Thinking About Systems of Systems. Working Paper, prepared for the Symposium on Complex System Engineering, January 11-12, 2006. RAND, Santa Monica, California.

9. Davis K., P. (2007 b). Rethinking Defense Planning. The RAND Corporation. Santa Monica, California. Dosegljivo na spletu: www.nyu.edu/brademas/pdf/legislating-futuredavis.pdf (19. 11. 2016).

10. Gaddis, L. J. (2009). What is Grand Strategy. Predavanje v okviru konference American Grand Strategy after the War. Triangle Institute for Security Studies in the Duke University Program, 26. februar 2009. Dostopno na: http://tiss-nc.org/wp-content/ uploads/2015/01/KEYNOTE.Gaddis50thAniv2009.pdf(11. 11. 2016).

11. Grant, G., R. (2014). 1. svetovna vojna: veliki ilustrirani vodnik. Mladinska knjiga, Ljubljana.

12. Grant, G., R. (2016). Bojevanje: velika slikovna enciklopedija. Mladinska knjiga, Ljubljana.

13. Gray, C. (2010). Strategic Thoughts for Defence Planners. Revija Survival, volume 52, no. 3, 159-178. The International Institute for Strategic Studies, Washington.

14. Gray, C. (2014 a). Defense Planning for National Security: Navigation Aids for the Mystery Tour. Strategic Studies Institute and U.S. Army War College Press. Dosegljivo na spletu: www.StrategicStudiesInstitute.army.mil (22. 11. 2016).

15. Gray, C. (2014 b). Strategy and Defence Planning: Meeting the Challenge of Uncertainty. Oxford University Press, Velika Britanija.

16. Grizold, A. (1989). Znanstvena dejavnost in obramba. Prispevek v razdelku strokovna in znanstvena srečanja. Teorija in praksa, letnik 26, številka 11-12, Ljubljana, 1613-1616.

17. Harmelink, D., J. (2001). Linear scheduling model: Float characteristics. Journal of construction engineering and management, 127 (4), 255-260.

18. Hart, L. (1967). Strategy: The Classic Book on Military Strategy. Second Revised Edition. Faber\&Faber Ltd., London.

19. Hodgson, N. (et al.) (2009). Zgodovina. Velika ilustrirana enciklopedija. Založba Mladinska knjiga, 1. ponatis, Ljubljana.

20. Kane M. T. (2001). Military Logistics and Strategic Performance. Frank Cass, London.

21. Keegan, J. (2005). Zgodovina vojskovanja. Fakulteta za družbene vede, Littera Picta, Ljubljana.

22. Kotnik, I. (2017). Strokovno mnenje in sugestije o razumevanju obrambnega planiranja dr. Igorja Kotnika z vidika funkcije svetovalca načelnika Generalštaba Slovenske vojske in nekdanjega namestnika generalnega direktorja Direktorata za obrambno politiko na Ministrstvu za obrambo (3. 2. 2017).

23. Le Roux, L. (2002). The Military Budgeting Process: an Overview: Defence Planning, Programming and Budgeting. Accra, Ghana. Spletna stran: http://www.sipri.org (3. 2. 2017).

24. McMaster, R. H. (2008). Learning from Contemporary Conflicts to Prepare for Future War. Orbis, FPRI's Journal of Wrold Affairs, Volume 52, Number 4, Fall 2008.

25. Možina, S. (in drugi) (2002). Management: nova znanja za uspeh. Didakta, Radovljica.

26. Murray, W., Hart, Sinnreich, R., Lacey, J. (ed.) (2011). The Shaping of Grand Strategy: Policy, Diplomacy, and War. Cambridge University Press, Cambridge. 
27. Murray, W., Knox McGregor, Bernstein A. (ed) (1994). The Making of Strategy: Rulers, States, and War. Cambridge University Press, Velika Britanija.

28. Rozman, R. (in drugi) (1993). Management. Gospodarski vestnik, Zbirka Manager, Ljubljana.

29. Stergar, R. (2004). Slovenci in vojska, 1867-1914; slovenski odnos do vojaških vprašanj od uvedbe dualizma do začetka 1. svetovne vojne. Historia, znanstvena zbirka Oddelka za zgodovino Filozofske fakultete Univerze v Ljubljani.

30. Tavčar, M. (2005). Strateški management nepridobitnih organizacij. Fakulteta za management, Koper.

31. Vuk, P. (2016). Teoretični vidiki odnosa med strategijo in obrambnim planiranjem na varnostno-obrambnem in vojaškem področju. Sodobni vojaški izzivi, Znanstvenostrokovna publikacija Slovenske vojske, maj 2016-18/st. 1, Ministrstvo za obrambo, Ljubljana. 15-36.

32. Yarger, R., H. (2006). Strategic Theory for the 21st Century: The Little Book on Big Strategy. Washington: United States Government.

33. Yarger, R., H. (2008). Strategy and the National Security Professional: Strategic Thinking and Strategy Formulation in the 21st Century. Praeger Security International, Wesport, ZDA.

34. Žabkar, A. (2003). Marsova dediščina (Temelji vojaških ved, 1. knjiga). Fakulteta za družbene vede, Ljubljana. 


\section{KRIZNO UPRAVLJANJE NA OBRAMBNEM PODROČJU S POUDARKOM NA SLOVENSKI VOJSKI}

\section{CRISIS MANAGEMENT IN THE FIELD OF DEFENCE, WITH EMPHASIS ON THE SLOVENIAN ARMED FORCES}

Povzetek Varnost danes ni ogrožena le zaradi oboroženih konfliktov, temveč predvsem in vedno pogosteje zaradi kompleksnih kriz. Učinkovit odziv nanje zahteva od nacionalnovarnostnega sistema stalno prilagajanje in pripravljenost na nepredvidljivost varnostnih razmer s prožno strukturo, razvito koordinacijo in z zmogljivostmi, sposobnimi ukrepanja na podlagi sistemskih in jasnih pravil na področju kriznega upravljanja. Prispevek osvetljuje pomen kriznega upravljanja v sodobni družbi s poudarkom na obrambnem področju, na katerem na podlagi teoretičnih in praktičnih spoznanj daje predloge, ki bi lahko bili za Slovensko vojsko kakovosten izhodiščni okvir za razpravo pri oblikovanju nujnih odgovorov na sodobne izzive kriznega upravljanja. Slovenija, njen nacionalnovarnostni sistem in vse njegove sestavine, vključno s Slovensko vojsko, si ne smejo in ne morejo dovoliti, da krizo pričakajo nepripravljeni ter brez vnaprej izoblikovanega in delujočega celovitega koncepta na področju kriznega upravljanja.

Ključne besede

Abstract

\section{Kriza, krizno upravljanje, krizno odzivanje, vaje kriznega upravljanja.}

Today, security is not threatened only because of armed conflicts, but mostly and increasingly because of the complexity of crises. An effective response to those crises requires the national security system to constantly adapt and remain ready for the unpredictable nature of the security situation. This can be achieved with a flexible structure, well-developed coordination and capabilities apt to react on the basis of clear and system rules in the field of crisis management. The article highlights the importance of crisis management in the modern society with the emphasis on the field of defence. It provides theory- and practice-based suggestions, which could serve as a quality frame of reference for a discussion in the process of preparing crucial responses to the contemporary challenges of crisis management. Slovenia, its 
national security system along with its components, including the Slovenian Armed Forces, cannot and should not presume to enter a crisis unprepared and without a pre-framed, effective and comprehensive crisis-management concept.

\section{Key words Crisis, crisis management, crisis response, crisis management exercises.}

Uvod Krize so pojav, ki danes še bolj kot v preteklosti zaznamujejo mednarodno varnostno okolje (teroristični napadi, naravne in tehnične nesreče, globalni problemi lakote, nalezljive bolezni, migracije, okoljski problemi, gospodarske krize idr.) in zahtevajo veliko družbene pozornosti, saj nanje ni nihče absolutno odporen. Razumevanje krize kot situacije, ki ogroža temeljne družbene vrednote, prinaša veliko negotovosti in dopušča relativno kratek čas za ukrepanje, zahteva od varnostnih in obrambnih instrumentov pravočasno, usklajeno in učinkovito ukrepanje, z vnaprej pripravljenimi in celostno usklajenimi mehanizmi kriznega upravljanja, vodenja in odzivanja. V tem pogledu predstavlja povezljiv in funkcionalen sistem kriznega upravljanja temeljni predpogoj uspešnega operativnega načrtovanja na področju kriznega upravljanja tako v mednarodnih integracijah kot tudi nacionalnih okvirih.

Temu dejstvu mora slediti Republika Slovenija (RS) z nujnim premislekom o posodobitvi oziroma dopolnitvi kriznega upravljanja in vodenja (KUV), ki bo temeljila na medresorski povezanosti ter prožnem odzivanju na kompleksne krize. Na ravni Vlade RS je projektna skupina ${ }^{1}$ že pripravila predlog nove strukture KUV (pri sklicevanju na to skupino bomo uporabili naziv vladna projektna skupina). $\mathrm{Na}$ vrsti so sestavine nacionalnovarnostnega sistema, torej tudi obrambni sistem ter znotraj njega Slovenska vojska (SV), da pregledajo sedanje stanje na področju kriznega upravljanja ter ga uskladijo z rešitvami vladne projektne skupine in umestijo v okolje integracij, znotraj katerih delujejo. Vprašanji, ki si ju moramo pri tem zastaviti, sta: »Ali je SV s svojimi zmogljivostmi optimalno vpeta $\mathrm{v}$ sistem kriznega upravljanja na obrambnem področju in kako učinkovito se lahko spoprime s krizo?«

Glavno raziskovalno vprašanje prispevka izhaja iz trditve, da umestitev SV v sistem kriznega upravljanja na obrambnem področju ni celovita, kar posledično zmanjšuje njeno vlogo pri delovanju in uresničevanju ciljev kriznega upravljanja in pri odzivanju na krize. Prispevek se osredotoča na model in procese kriznega upravljanja na obrambnem področju v krizi, ne glede na dejstvo, ali SV deluje v okviru zaščite, reševanja in pomoči, v okviru policije ali samostojno, doma ali na kriznih območjih, pod nacionalno ali zavezniško zastavo. Gre za proces upravljanja, vodenja in

\footnotetext{
Ministrstvo za obrambo je prevzelo vodenje enega izmed vladnih strateških projektov, in sicer P7: Sistem kriznega upravljanja in vodenja $v$ RS, sofinanciranega iz evropskega sklada za notranjo varnost. Projekt Sistem kriznega upravljanja in vodenja predvideva pripravo predloga strukture kriznega upravljanja in vodenja pri Vladi RS za odzivanje na kompleksne krize, izpopolnitev mehanizmov za njihovo upravljanje ter predlog normativnopravnih rešitev. Delni rezultati omenjenega vladnega strateškega projekta so bili predstavljeni v publikaciji z naslovom Upravljanje kompleksnih kriz v Republiki Sloveniji (Vuga Beršnak (ur.), 2016).
} 
odzivanja na krizo pred in med krizo ter po njej, ki bi moral biti izoblikovan, celovit in preizkušen ter usklajen z nacionalnim in Natovim ter EU-procesom kriznega upravljanja. Končni cilj prispevka je (1) razširiti zavedanje tako znotraj SV kot tudi širše, da je krizno upravljanje ključni dejavnik načrtovanja in odločanja v krizni situaciji na obrambnem področju, in (2) na podlagi pridobljenih spoznanj predstaviti idejni koncept kriznega upravljanja v SV na obrambnem področju.

\section{KRIZA IN KRIZNO UPRAVLJANJE}

V prispevku obravnavamo pojem kriza dovolj splošno, da lahko zajamemo njegovo uporabnost tako v nacionalnem kot tudi mednarodnem okolju. Takšno opredelitev krize navaja na primer Malešič $(2004,11-12)$, in sicer, da gre pri krizi za krizno situacijo, v kateri so ogrožene temeljne družbene vrednote, norme in strukture, v kateri je čas za odločanje omejen in ki prinaša negotovost, stres, pogosto tudi presenečenje $\mathrm{e}^{2}$.

V času intenzivne informatizacije in tehnološkega napredka, globalizacije, hibridnih groženj ipd. je treba gledati na krizo tudi kot na kompleksen družbeni pojav, z vplivom na različna področja varnosti, transnacionalnim učinkom ter akumulacijo negativnih učinkov, ki se pogosto pojavijo po umiritvi krizne situacije (okoljski problemi, kriminal, spori itn.). Celovitejši pogled na sodobno razumevanje krize, ki jo v literaturi zasledimo pod pojmom kompleksna kriza, je praviloma povezan še s povečano občutljivostjo ljudi na krize in zmanjšano sposobnostjo sistema za učinkovito odzivanje na vseh prizadetih področjih. Kompleksna kriza nastane takrat, ko se grožnja eni prvini v trenutku razširi na druge in je opredeljena opisno, največkrat z značilnostmi prepletene grožnje, učinkom domin, nelinearnim procesom, negativnimi dogodki s sinergijskim učinkom, visoko stopnjo tveganja ipd. Zato je za krizno upravljanje pomembno vedeti, ali imamo opravka s kompleksno krizo, saj je za njeno reševanje nujen celovit pristop h kriznemu upravljanju ${ }^{3}$. Tudi vladna projektna skupina poudarja pomen termina kompleksna kriza, ki ga opredeljuje kot

\footnotetext{
Opredelitev krize kot pojma najdemo na normativnem področju v nacionalnem prostoru tudi v predlogu novele Zakona o obrambi, kar je novost. Kriza je v njem opredeljena kot stanje pravne kategorije, ki nastane kot posledica dogodkov, ki ogrožajo varnost (nacionalno ali mednarodno) in lahko vodijo tudi v izredno stanje ali vojno. Za njeno obvladovanje je treba uveljaviti ustrezne ukrepe kriznega odzivanja, ob upoštevanju obveznosti, prevzetih s članstvom v mednarodnih organizacijah (EVA 2016-1911-0001). Z vidika problematike proučevanja pa je najpomembneje, da predlog zakona povsem na novo predvideva načrtovanje delovanja obrambnega sistema v kriznih razmerah. Gre za novost, na podlagi katere bo mogoče oblikovati temeljne usmeritve za organizacijo kriznega upravljanja znotraj SV. Zanimiva je tudi opredelitev pojma kriza z vidika vladne projektne skupine (Vuga in Ferlin, 2016, str. 3). Krizo razumejo kot: »razmere ogrožanja temeljnih družbenih vrednot, velike negotovosti in razmeroma kratkega časa za ukrepanje, ki presega odzivne zmožnosti posameznih resorjev ali podsistemov nacionalne varnosti«. Splošnejše opredelitve pojma krize, kot situacije, ki ogroža nacionalno ali mednarodno varnosti ter glavne družbene vrednote in zahteva takojšen odziv nanjo (Ekengren, Groenleer, 2006, 85-87), najdemo tudi v mednarodnem okolju (Nato, EU).

3 Več o tem Malešič, 2008, 116, Prezelj, 2005, str. 47-48. Prezelj (2005, 45-46) na primer v tem smislu razlikuje med enodimenzionalnimi in večdimenzionalnimi krizami, pri čemer je za reševanje enodimenzionalne krize z nizko kompleksnostjo dovolj, če jih rešuje ena dimenzija kriznega upravljanja. Pri večdimenzionalnih, visoko kompleksnih krizah pa pri reševanju sodeluje celoten spekter akterjev kriznega upravljanja.
} 
stanje, ko kriza dobi takšne razsežnosti, da je en akter ne zmore več samostojno upravljati in se upravljanje in vodenje odzivanja na krizo preneseta na Vlado $\mathrm{RS}^{4}$.

Poleg značilnosti kriz je za izoblikovanje procesa kriznega upravljanja pomembno tudi poznavanje poteka krize, ki običajno sledi določenemu vzorcu. Iz skice 1 je razviden potek krize, ki v svojem razvoju preide tri faze. V predkriznem času se pojavljajo grožnje, napetosti, težave, ki lahko vodijo do krize in ob ustreznem spremljanju situacije omogočijo prepoznavanje nastajanja krize in preventivno delovanje. Na točki izbruha krize prehaja krivulja $\mathrm{v}$ fazo krize, pri čemer nastaneta eskalacija razmer in vrhunec krizne situacije (v najbolj ekstremni obliki - vojna). Z umirjanjem situacije prehaja kriza v pokrizno obdobje, za katerega sta značilni stabilizacija in normalizacija stanja.

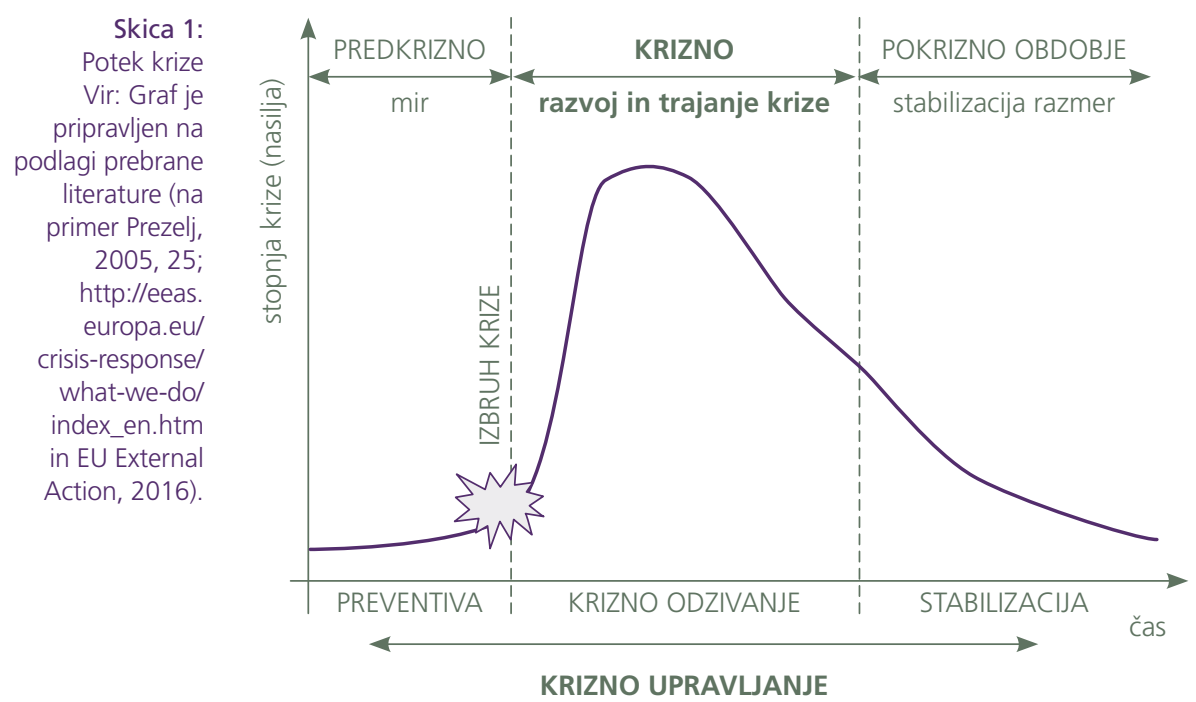

$\mathrm{Na}$ krizo se tesno navezujejo termini krizno upravljanje, krizno odzivanje in krizno vodenje. Terminološko na tem področju ni dorečeno, kdaj se uporabi določena besedna zveza, prav tako ni zaslediti enotne rabe pojmov pri obravnavanih subjektih $^{5}$.V prispevku je dosledno uporabljen termin krizno upravljanje, ki ga razumemo kot spremljanje krize pred nastankom ter kot preventivno odzivanje in ukrepanje ob izbruhu krize ter kot stabilizacijo po krizi.

\footnotetext{
4 Posledično delijo krize na področne (en resor samostojno obvladuje področje krize) in kompleksne krize (upravljanje se prenese na vlado, ki običajno aktivira strukturo kriznega upravljanja) (Vuga, Ferlin, 2016, 4).

5 Nato na primer dosledno uporablja termin »crisis management«, EU največkrat uporablja »crisis response" pa tudi »crisis management«, vladna projektna skupina uvaja pojem krizno upravljanje in vodenje (KUV) ipd. Tudi pri prevajanju »crisis management « ni mogoče najti enotne rabe, ali krizno upravljanje ali KUV.
} 
Krizno upravljanje je v slovenski literaturi temeljito opredelil Malešič $(2004,14)$, in sicer kot oblikovanje postopkov, dogovorov in odločitev, ki vplivajo na potek krize, in obsega organizacijo, priprave, ukrepe ter razporeditev virov za njeno obvladovanje. Krizno upravljanje običajno poteka v organizacijskem kaosu, pod pritiskom množičnih občil, V stresnih razmerah in ob pomanjkanju natančnih informacij. Spremembe narave in konteksta sodobnih kriz pa krizno upravljanje še otežujejo, saj so sodobne krize zelo kompleksne, učinkujejo prek različnih »meja« in so praviloma dolgotrajne ${ }^{6}$.

Izpostaviti je treba še eno pojmovno različico, in sicer krizno upravljanje in vodenje (KUV). Razlikovanje med avtorji, ki uporabljajo izraz krizno upravljanje, in avtorji, ki uporabljajo izraz KUV, je glede na proučeno le v tem, da tisti, ki dodajajo terminu še besedo vodenje, želijo posebej poudariti pomen vodenja v krizi, čeprav po drugi strani tudi tisti, ki besede vodenje ne uporabljajo pri opredeljevanju pojma, prav tako poudarjajo ključno vlogo vodenja. Sklepamo lahko, da je razumevanje izrazov vsebinsko izenačeno, za razliko od pojma krizno odzivanje, ki je po teoriji le del upravljanja (in vodenja).

\section{SISTEM KRIZNEGA UPRAVLJANJA V NATU IN EU}

\subsection{Krizno upravljanje v Natu}

Natov proces kriznega upravljanja (Nato Crisis Management Process - NCMP) je določen v Priročniku o Natovem sistemu odzivanja na krize (Nato Crisis Response System Manual- NCRSM) ${ }^{8}$, ki se praviloma posodablja vsako leto. Kot del operativnega procesa načrtovanja omogoča zavezništvu učinkovit pristop $\mathrm{k}$ preprečevanju konfliktov in uspešno upravljanje kriz. Zato je za zavezništvo zelo pomembno pravočasno izvajanje postopkov kriznega upravljanja, po možnosti že ob zaznavi prvih kazalnikov verjetnega izbruha krize, da se omogoči dovolj časa za sprejemanje usklajenih in najboljših rešitev.

NCMP je šestfazni postopek ocenjevanja situacije, posvetovanja, sprejemanja odločitev in odzivanja na (prihajajoče) krizne situacije.

\section{1. faza: kazalci in opozorila o morebitni prihajajoči krizi}

Proces spremljanja situacije in ogrožanja varnosti je stalen proces zavezništva, ki se neprekinjeno dopolnjuje $\mathrm{z}$ novimi podatki. Praviloma ga izvajajo

\footnotetext{
Nacionalna zakonodaja opredeljuje krizno upravljanje v drugem členu Uredbe o obrambnem načrtovanju (2013), ki pravi, da je krizno upravljanje enoten sistem organiziranosti, postopkov, aktivnosti in ukrepov z namenom učinkovitega obvladovanja kriznih razmer. Podobno opredeljuje termin tudi Vojaška doktrina.

Zaradi stopnje tajnosti dokumenta je vsebina NCMP predstavljena na podlagi javno dostopnih virov (zlasti Natovih spletnih strani http://www.nato.int/cps/en/natohq/official_texts_75565.htm? in http://www.nato.int/cps/ en/natolive/topics_49192.htm), priročnik NCRSM pa sta avtorja uporabljala zgolj kot oporo pri razumevanju koncepta Natovega procesa kriznega upravljanja.

$\&$ Zaradi stopnje tajnosti dokumenta je vsebina NCMP predstavljena na podlagi javno dostopnih virov, omenjeni priročnik je za avtorje zgolj opora pri razumevanju koncepta Natovega procesa kriznega upravljanja.
} 
obveščevalno-varnostne službe in službe za zgodnje opozarjanje ali kar članice. Njihova poročila predstavljajo izhodišče za prehod v naslednjo fazo in v posvetovalni proces Severnoatlantskega sveta (North Atlantic Council - NAC). Obstajajo štiri možnosti odziva na poročila: (1) sprejetje odločitve, da ni nujno nadaljnje ukrepanje; (2) odločitev, ki predvideva povečanje budnosti in pozornosti ter zagotavljanje dodatnih informacij v NAC; (3) NAC sprejme mnenje za začetek uvajanja določenih kriznih ukrepov na politični in varnostni ravni ter sprejetje preventivnih ukrepov $\mathrm{v}$ nujnih primerih. Ob takem odzivu se ustanovi civilno-vojaška delovna skupina za krizno odzivanje (Civil Military Task Force - CMTF); (4) prehod v fazi dve in tri s pripravo celovite ocene ogroženosti/krizne situacije.

\section{2. in 3. faza: ocena krizne situacije in oblikovanje mogočih oblik odzivanja}

NAC sprejme politično vojaško oceno (Political Military Estimate - PME) in poglobljeno obveščevalno analizo, ki je podlaga za pripravo strateškega vojaškopolitičnega načrta, s katerim se želijo doseči zastavljeno končno stanje in cilji zavezništva. Vrhovni poveljnik zavezniških sil za Evropo (Supreme Allied Commander Europe - SACEUR) mora pripraviti strateško oceno (SACEUR Strategic Assesment - SSA), ki je podlaga za pripravo strateškega vojaškega nasveta (Strategic Military Advice - SMA), ki ga pripravlja mednarodni vojaški štab (International Military Staff - IMS), odobri pa vojaški odbor (Military Committee - MC). SMA je podlaga za pripravo političnega nasveta s poglobljeno analizo varnostne situacije in za oblikovanje različic delovanja, ki predstavljajo tretjo fazo kriznega upravljanja. $\mathrm{V}$ tretji fazi se pripravijo začetne smernice (Nato Initiating Directive - NID) ${ }^{9}$, s katerimi se opredelijo cilji zavezništva, želeno končno stanje in ukrepi kriznega odzivanja. Ne glede na to, da se v tej fazi še ne oblikujejo odločitve zavezništva o vojaškem posredovanju, ker so še vse možnosti odprte za politično in diplomatsko presojo, SACEUR oblikuje možnosti vojaškega odziva (Military Response Options $\mathrm{MRO}$ ), članice pa formalno najavijo pripravljenost za sodelovanje.

\section{4. faza: načrtovanje}

Načrtovanje je najpomembnejša faza, pri kateri se oblikujejo ključni dokumenti za izvedbo odzivanja na situacijo. SACEUR v tej fazi razvije koncept operacij (Concept of Operations - CONOPS), ki mu sledi načrt operacij (Operations Plan - OPLAN). Dokumenta morata potrditi MC in NAC. Sočasno se začnejo procesi nabora sil in aktivacije. Na prehodu faze se oblikuje še izvršna direktiva (Nato Executive Directive - NED). Vse to je podlaga vojaški veji oblasti zavezništva, da preide $\mathrm{v}$ peto fazo kriznega upravljanja.

\section{5. faza: izvedba odločitev in direktiv NAC}

Po odobritvi vseh dokumentov in NED, ki predstavlja politično avtorizacijo, se začnejo posamezne operacije. Ves čas trajanja faze se periodično izvaja pregled

\footnotetext{
9 Na podlagi oblikovanih smernic lahko SACEUR začne operativno načrtovati, najprej s pripravo MRO.
} 
stanja (Periodic Mission Review - PMR), na podlagi katerega se odloča o prehodu v zadnjo fazo in o nadaljevanju operacije ali spremembah nekaterih ukrepov ${ }^{10}$.

\section{6. faza: vzpostavitev stabilnosti}

$\mathrm{V}$ tej fazi so pomembni prenos odgovornosti, dokončanje vojaških in drugih aktivnosti ter postopen umik Natovih sil z območja delovanja.

Nato je sistem odzivanja na krize (NCRS) in znotraj njega proces kriznega upravljanja (NCMP) začel posodabljati leta 2010 na podlagi sistemov za pripravljenost (Nato Alert System - NAS) in preventivo (Nato Precautionary System - NPS). Omogoča odziv v obliki celovitega pristopa vseh članic in hkrati ostaja dovolj prožen za nenehno prilagajanje spremembam v okolju.

\subsection{Krizno upravljanje v EU}

Po uveljavitvi Lizbonske pogodbe leta 2009 se proces kriznega upravljanja EU vključuje v skupno zunanjo in varnostno politiko (SZVP) ter znotraj nje v skupno varnostno in obrambno politiko (SVOP). Namen SVOP je krepitev civilnih in vojaških zmogljivosti EU za preprečevanje konfliktov in krizno upravljanje. Z zagotavljanjem učinkovitega odzivanja na krize prehaja EU iz »celostnega pristopa« v »celostno ukrepanje«, ki je prav tako uveljavljeno v vseh fazah razvoja in upravljanja kriz (od prvih informacij o prihajajoči krizi do pokrizne obnove in stabilizacije) (Skupna zunanja in varnostna politika, 2016).

Osrednjo vlogo v kriznem upravljanju EU imata Evropska služba za zunanje zadeve (The European External Action Service - EEAS) in Oddelek za krizno odzivanje in operativno načrtovanje (Crisis Response and Operational Coordination Department). Odgovorna sta za aktivacijo sistema EEAS za krizno odzivanje, ki je sestavljen iz treh elementov: Osnovne krizne celice (Crisis Platform), Situacijske sobe (EU Situation Room) in Odbora za krizno upravljanje (Crisis Management Board). Ključni akterji na instrumentalno-upravni ravni kriznega upravljanja EU, ki sestavljajo t. i. Crisis Platform, so: Direktorat za krizno upravljanje in načrtovanje (Crisis Management and Plans Directorate - CMPD) ${ }^{11}$, Vojaški štab EU (EU Military Staff - EUMS), situacijski center EU (SitCen), Vojaški odbor (EU Military Committee - EUMC) in druge nujne komisije EU, Civilne zmogljivosti za načrtovanje in izvajanje operacij (Civilian Planning and Conduct Capability - CPCC), Center za operacije EU (EU Operations Centre) in Center za obveščevalne analize (Inteligence Centre). Predsedujoča vzpostavljenemu sistemu je Visoka predstavnica EU ali tudi izvršni direktor EEAS (ESG). Države članice se vključujejo z osebjem v stalnem

\footnotetext{
${ }^{10}$ Isaf in Kfor sta primera operacij, ki sta v peti fazi procesa kriznega upravljanja.

${ }^{\prime \prime}$ CMDP je center SVOP, odgovoren za integrirano civilno-vojaško načrtovanje v EEAS. Vpleten je v vse strukture kriznega upravljanja EU in je glavni sestavni del odločanja v EEAS. CMDP deluje pod nadzorom Političnega in varnostnega odbora EU (Political and Security Committee - PSC), ki ga sestavljajo predstavniki vseh držav članic. Hkrati je strokovni in podporni organ visoki predstavnici EU (EU External Action, 2016).
} 
predstavništvu pri EU (in Natu) ter neposredno iz države, z obrambnega ministrstva in ministrstva za zunanje zadeve (Blagonič, 2014, 40, in EU External Action, 2016) ${ }^{12}$.

Znotraj SVOP izvaja EU integrirano (civilno-vojaško) strateško načrtovanje za razvoj možnosti delovanja EU v kriznih razmerah. Predstavljene so v t. i. Konceptu kriznega upravljanja (Crisis Management Concept - CMC), ki ga potrdijo ministri EU in je podlaga za odločanje v Svetu EU. EU je od sprejema Lizbonske pogodbe do danes zelo napredovala $\mathrm{v}$ smeri ureditve področja kriznega upravljanja, tako na organizacijski kot procesni ravni. Z oblikovanjem SZVP/SVOP je razvila koncept sodelovanja med državami v postopkih upravljanja kriz, kar ji omogoča aktivno sodelovanje pri normalizaciji stanja v kriznih situacijah po svetu. Največji napredek $\mathrm{v}$ sodelovanju in povezovanju mednarodne skupnosti $\mathrm{v}$ reševanju kriz pa še vedno pomeni t. i. aranžma Berlin plus ${ }^{13}$, ki EU omogoča dostop in uporabo Natovih zmogljivosti načrtovanja in njihove uporabe na področju kriznega upravljanja.

\subsection{Krizno upravljanje v Republiki Sloveniji}

V Sloveniji je po sedanji ureditvi vsak resor odgovoren za reševanje kriz na svojem področju, njihovo delo pa usklajuje Vlada RS. Njen politični svetovalni organ je Svet za nacionalno varnost (SNAV) ${ }^{14}$, katerega operativni del predstavlja Sekretariat SNAV (SSNAV), tehnično podporo vladi zagotavlja Nacionalni center kriznega upravljanja (NCKU) ${ }^{15}$, znotraj katerega deluje tudi Medresorska analitična skupina (MAS), ki zagotavlja strokovno podporo odločevalnim organom ob pojavu krize. Celotna struktura v Sloveniji je usmerjena zgolj v krizno odzivanje, zaščito kritične infrastrukture in sprejemanje mehanizmov za reševanje kriz.

$\mathrm{Na}$ pomanjkljivosti nedokončanega oblikovanja sistema kriznega upravljanja opozarjajo tako strokovnjaki s področja kriznega upravljanja ${ }^{16}$ kot tudi ugotovitve praktičnih izkušenj RS s periodičnih vaj kriznega upravljanja znotraj Nata in EU. Vlada RS je za reševanje tega problema leta 2016 imenovala že omenjeno vladno

\footnotetext{
12 Situacijska soba predstavlja krizni center EU, ki zagotavlja neprekinjeno opazovanje in spremljanje situacije. Odbor za krizno upravljanje usklajuje aktivnosti EU med krizo. Del oddelka kriznega odzivanja je tudi svetovalni oddelek za krizno odzivanje, ki ima dve vlogi: pomaga pri koordinaciji kriznih politik vseh članic in vodi usklajevanje aktivnosti med članicami. Vzpostavitev takšnega mehanizma omogoča izvajanje celovitega pristopa in celovitih akcij ter omogoča planiranje vnaprej kot tudi sprejemanje ad hoc rešitev. Struktura zagotavlja politične in strateške usmeritve za EEAS.

${ }_{13}$ Dogovor med Natom in EU (Berlin, 16. 12. 2002) v zvezi s sklepi washingtonskega vrha zavezništva leta 1999, da lahko EU na podlagi t. i. pogoja "Right of First Refusal" uporablja določene Natove vojaške zmogljivosti, če zavezništvo nima namena posredovati v operaciji kriznega odzivanja, za katero kaže zanimanje EU.

${ }^{14}$ Naloge SNAV znotraj sistema kriznega upravljanja so: svetovanje vladi pri sprejemanju ukrepov s področja nacionalne varnosti, usklajevanje mnenj ministrstev in drugih državnih organov s področja nacionalne varnosti, ocenjevanje varnostnega tveganja ogrožanja države in dajanje mnenj $k$ vprašanjem s področja nacionalne varnosti (Odlok o SNAV,Uradni list 70/2013).

${ }^{15}$ NCKU je organiziran na MO, njegovo stalno jedro pa deluje neprekinjeno. Naloga NCKU je zagotovitev tehnične, komunikacijsko-informacijske podpore delovanju Vlade RS v kriznih razmerah, skladno z Zakonom o izrednem in vojnem stanju ali ob pojavih kriz v okolju, ki ogrožajo nacionalno varnost. Organizacijo naloge, delo ipd. določa Odredba o organizaciji in delovanju NCKU.

${ }^{16}$ Malešič, 2008; Vuga, Ferlin, 2016; Prezelj, 2005, itn.
} 
projektno skupino, da razišče možnosti (pre)oblikovanja strukture KUV na ravni države in izpopolnitve postopkov ter delovanja kriznega upravljanja in drugih mehanizmov kriznega upravljanja, primerljivih z uveljavljenimi sistemi v Natu in EU. Pomembna naloga projektne skupine se nanaša tudi na iskanje ustreznih normativnopravnih rešitev, ki bi zagotavljale dovolj dobre (celovite in prožne) sistemske podlage za učinkovito delovanja kriznega upravljanja na nacionalni ravni.

\subsubsection{Predlog strukture KUV pri Vladi RS ${ }^{17}$}

Predlog nove strukture KUV se opira na nujne funkcije ${ }^{18}$ za upravljanje kriz, na omejenost finančnih in kadrovskih virov ter na zagotavljanje maksimalne učinkovitosti. Normativnopravno naj bi bila umeščena v zakon o vladi, natančneje pa bi njegovo delovanje urejal podzakonski akt (na primer uredba o kriznem upravljanju in vodenju). Struktura bi imela en stalni organ, drugi pa bi se aktivirali ob pojavu krize. Glavni cilj takšne ureditve je zagotavljanje optimalnega in usklajenega delovanja vseh resorjev ter podsistemov nacionalnovarnostnega sistema. Sedanja telesa (SNAV, SSNAV, MAS in NCKU) bi povezala v skupno strukturo in jih dopolnila s stalno operativno skupino pri SSNAV ter medresorsko skupino za spremljanje situacije in usklajevanje. Takšna struktura bi bila umeščena vertikalno, h generalnemu sekretariatu vlade ali v kabinet predsednika vlade. Zato bi bilo smiselno okrepiti in zvišati stopnjo institucionaliziranosti funkcije svetovalca predsednika vlade za nacionalno varnost, ki je hkrati vodja SSNAV ${ }^{19}$. Ob krizi bi bila tako vnaprej določena oseba, ki bi prevzela usklajevalno vlogo, po pooblastilu vlade pa tudi vodstveno ${ }^{20}$. Predlagana struktura KUV pri vladi ne posega v pristojnosti ali delovanje resorjev in podsistemov nacionalnovarnostnega sistema, namenjena je le podpori odločanja Vlade RS pri odzivanju na kompleksne krize.

Postopek KUV po tej strukturi bi začela izvajati Vlada RS z aktivacijo NCKU. Vladi bi stalno obveščenost zagotavljal SSNAV, ki samostojno odloča o zadevah ali odločanje s pooblastilom preda vodji SSNAV. SSNAV je stalno telo, ki se ob pojavu krize preoblikuje v operativno-usklajevalno telo in prevzame (vodja SSNAV) ključno krizno usklajevanje med resorji. SNAV ostaja posvetovalno telo, ki pa se po potrebi tudi razširi na nestalne resorje. Medresorska analitična skupina MAS in Medresorska skupina za spremljanje situacije in usklajevanje (MS3U) morata delovati skupaj in usklajeno ter pripraviti enotno poročilo za SSNAV (že v miru) ter scenarije razvoja dogodkov in rešitev. Predlog ukrepov sprejme ožja skupina

\footnotetext{
${ }^{17}$ Poglavje temelji na prispevku avtoric Vuga in Ferlin (2016, 9-32), v katerem predstavljata koncept vladne projektne skupine o vzpostavitvi celovite strukture KUV pri Vladi RS.

${ }^{18}$ Funkcije, nujne za upravljanje kompleksnih kriz, so spremljanje situacije in ogroženosti, analiziranje in predvidevanje, svetovanje, odločanje, usklajevanje in vodenje, komuniciranje, enotna pokrizna analiza, podporne funkcije (na primer psihosocialna pomoč) (Vuga, Ferlin, 2016, 13).

19 Kot drugo, a slabšo možnost sestavljavci sistema predlagajo, da vodenje v krizi prevzame minister ali državni sekretar, na čigar področju je kriza izbruhnila.

${ }^{20}$ Predlagana funkcija zahteva visoko stopnjo strokovnega znanja, izkušenj, posebnih osebnostnih lastnosti in prevzemanje odgovornosti. Treba je določiti pogoje za imenovanje na mesto vodje SSNAV in hkrati svetovalca predsednika vlade za nacionalno varnost. Izpolnitev teh pogojev bi pripomogla pri vzpostavitvi sistema dolgoročnega oblikovanja tako imenovanih kriznih vodij (Vuga, Ferlin, 2016, 21).
} 
svetovalcev vodje SSNAV. Vodja SSNAV jih pošlje v obravnavo SNAV, ki predstavi svoje mnenje, predloge in dopolnila. Nato vodja SSNAV predlog rešitev in ukrepov posreduje predsedniku vlade in vladi.

Predstavljena ureditev področja kriznega upravljanja pomeni najboljšo mogočo rešitev $\mathrm{v}$ tem trenutku, tako $\mathrm{v}$ nacionalnem kot $\mathrm{v}$ mednarodnem okolju. Upošteva nacionalne omejitve in zaveze, ki izhajajo iz mednarodnih integracij ter omogoča podsistemom nacionalne varnosti, ki se spoprijemajo s krizo, da uskladijo svoje koncepte z njim.

\section{UMEŠČENOST SLOVENSKE VOJSKE V SISTEMIH KRIZNEGA UPRAVLJANJA}

\subsection{Analiza pravnih virov s področja kriznega upravljanja}

$\mathrm{Z}$ analizo primarnih virov smo ugotavljali normativno urejenost področja kriznega upravljanja na nacionalni ravni. Obsegala je analize Ustave RS, aktualnega Zakona o obrambi in novele Zakona o obrambi, Zakona o varstvu pred naravnimi in drugimi nesrečami, Resolucije o strategiji nacionalne varnosti, Obrambne strategije RS, Vojaške doktrine, Strateškega pregleda obrambe 2016, Strategije sodelovanja RS v mednarodnih operacijah in na misijah, Uredbe o organizaciji in delovanju Nacionalnega centra za krizno upravljanje in Uredbe o obrambnem načrtovanju. Zaradi obsežnosti analize $\mathrm{v}$ nadaljevanju izpostavljamo zgolj njene ključne ugotovitve, pomembne za oblikovanje sklepov.

Skupno vsem dokumentom je, da poudarjajo težo usklajenega in celovitega pristopa (nacionalno in mednarodno) k načrtovanju upravljanja kriz in reševanju nastalih kriznih situacij, ne glede na meje in naravo krize. Zakonodaja ne omejuje sodelovanja SV v kriznih situacijah, vendar je njena aktivacija odvisna od drugih subjektov v nacionalnovarnostnem sistemu (Civilna zaščita, predsednik RS ipd.) in je pretoga za hitro odzivanje. Pregled zakonodaje dokazuje, da procesi in postopki znotraj SV in MO RS niso usklajeni niti jasno opredeljeni. Ni opredeljenih nosilcev nalog ali postopkov, med posameznimi segmenti ni logičnih povezav, določeni deli odločanja in načrtovanja v krizi pa sploh niso zaznani niti razviti. Proces kriznega upravljanja je zastavljen kot ad hoc proces kriznega odzivanja, saj postopki pred krizo in po njej niso institucionalizirani, zato se v odločilnih trenutkih SV kot ustanova pogosto znajde $\mathrm{v}$ precepu in je edino mogoč le še odziv. V proučevanih predpisih ni nikjer zaslediti navajanja Natovih ali EU-dokumentov, ki bi morali predstavljati vhodne parametre za organiziranost kriznega upravljanja na nacionalni ravni. Sklepamo lahko, da proces kriznega upravljanja v SV z vidika analize pravnih virov ni opredeljen. Pomembna je tudi ugotovitev, da je proces kriznega upravljanja v RS parcialno in razpršeno zajet v vseh zgoraj navedenih pravnih aktih, manjka pa celovita normativnopravna rešitev, ki bi jasno opredelila in določila pravila delovanja vseh akterjev kriznega upravljanja, na kar opozarja tudi vladna projektna skupina. 


\subsection{Slovenska vojska v sistemu kriznega upravljanja}

Koncept kriznega odzivanja na obrambnem področju je bil oblikovan na podlagi 16. člena Zakona o obrambi in sklepa Vlade RS o pripravah za izvajanje Natovih ukrepov ob krizah ${ }^{21}$. Skladno s tem konceptom deluje v upravnem delu Ministrstva za obrambo, Direktoratu za obrambne zadeve, Oddelek za obrambno krizno načrtovanje, ki usklajuje in izvaja naloge kriznega načrtovanja na obrambnem področju ter sodeluje pri ocenjevanju tveganj in ogrožanja nacionalne varnosti. Na oddelku se načrtujejo pogoji za delo predsednika države, Vlade RS in Državnega zbora RS $\mathrm{v}$ izrednih razmerah in vojni. Tam se tudi usklajujejo priprave državnih organov za zaščito kritične infrastrukture $v$ državi. Za zagotavljanje civilnih zmogljivosti $\mathrm{v}$ podporo SV in medresorsko koordinacijo pa je bil $\mathrm{v}$ omenjenem direktoratu ustanovljen Oddelek za civilne zmogljivosti in krizno odzivanje. Na področju kriznega odzivanja izvaja aktivnosti odziva na krize znotraj EU in Nata. Strokovno pomaga izvajalcem ukrepov NCRS in jih podpira pri kriznem komunikacijskem informacijskem sistemu, ki je del t. i. informacijskega sistema v podporo odločanju (ISPO). Podpira delovanje Natovega Odbora za civilno krizno načrtovanje (Civil Emergency Planning Committee - CEPC).

SV se vključuje v sistem varstva pred naravnimi in drugimi nesrečami s sodelovanjem in izvajanjem nalog pri zaščiti in reševanju ob naravnih in drugih nesrečah, skladno s svojo organiziranostjo in opremljenostjo (37. člen ZObr). Za to ima SV, na podlagi državnih načrtov zaščite in reševanja, za posamezno vrsto nesreče pripravljene dokumente (načrte delovanja SV) za ukrepanje ob velikem požaru, potresu, poplavi, uporabi orožja za množično uničevanje, terorizmu ipd., ki so združeni v načrtu Vihra. O sodelovanju SV pri nalogah zaščite in reševanja odloča Vlada RS, v nujnih primerih pa minister na predlog poveljnika Civilne zaščite RS oziroma načelnika GŠSV po pooblastilu ministra.

S Standardnim operativnim postopkom 03-003 (SOP) za krizno organiziranje GŠSV iz leta 2011 so opredeljena izhodišča za načrtovanje, organiziranje in vodenje GŠSV ob pojavu kriznih razmer. Dokument zagotavlja tudi usklajenost funkcijskih področij in usmeritve podrejenim poveljstvom ter enotam za vzdrževanje zahtevane ravni pripravljenosti SV. V njem so sicer jasno zapisane naloge po sektorjih in samostojnih poveljstvih, vendar brez opredelitve postopka kriznega upravljanja znotraj kabineta načelnika GŠSV oziroma SV (SOP, 03-003). Težava dokumenta je tudi dejstvo, da je bil napisan pred letom 2012, ko je bila izvedena zadnja transformacija SV. Tudi s tega vidika bi bilo treba vsebine pregledati in jih posodobiti. Za boljše razumevanje aktualnega delovanja in strukture SV je treba izpostaviti, da se delovanje SV po transformaciji usmerja prek Združenega operativnega centra $(\mathrm{ZOC})^{22}$, ki je jedro za organizacijo operativnega poveljevanja. Leta 2017 se struktura in obseg SV prilagajata ugotovitvam in predlaganim ukrepom Strateškega pregleda obrambe

\footnotetext{
${ }^{21}$ Sklep Vlade Republike Slovenije, št. 810-02/2002-2, z dne 16. 1. 2003.

${ }^{22}$ Med glavne naloge ZOC poleg drugih spadata tudi vodenje in usklajevanje uporabe zmogljivosti in enot $S V v$ sistemu varstva pred naravnimi in drugimi nesrečami ter ob njihovem aktiviranju v krizi.
} 
(2016), pri katerem bo med drugim do izraza prišla tudi ponovna vzpostavitev funkcije načelnika štaba GŠSV in Poveljstva sil. Te strukturne spremembe SV lahko z ustrezno in načrtno umestitvijo njihove vloge, kot bo prikazano v nadaljevanju tega prispevka, bistveno pripomorejo $\mathrm{k}$ sistemskim rešitvam in učinkovitosti delovanja SV na področju kriznega upravljanja.

Predstavljeni dokumenti (predvsem SOP) dobro opredeljujejo postopke kriznega odzivanja in namenskega organiziranja za delovanje v krizah, medtem ko se koncepta kriznega upravljanja ne lotevajo. Zato je treba sedanjo strukturo vzeti kot podlago, na kateri temelji celovit in učinkovit sistem kriznega upravljanja v SV.

\subsection{Ugotovitve Slovenske vojske z vaj kriznega upravljanja}

Cilj priprav in izvedbe vaj kriznega upravljanja na obrambnem področju v RS je preverjanje postopkov, usklajevanja in odziva SV, državnih in drugih organov ob zaostrovanju varnostnih razmer v mednarodnem in nacionalnem okolju. Na vajah se preverjajo rešitve, iščejo slabosti in uveljavljenost načel kriznega upravljanja EU ter Nata in povezljivost sistemov.

V prispevku so analizirane Natove (CMX) in EU (CME)-vaje kriznega odzivanja od leta 2012 ter vaja Vodstvene obrambno-zaščitne vaje Pomlad 2011. Skupaj gre za šest vaj, nekatere vmes niso bile izvedene (CMX13, CMX14 je bila izpeljana 2015), nekaterih pa se RS ni udeležila (vaji EU MILEX 2013 in 2015). Analiza se naslanja predvsem na zapis pomembnejših dobrih in slabih praks z omenjenih vaj ter podatke, ki so povezani s predmetom proučevanja in bi lahko koristno pripomogli k sklepnim ugotovitvam.

\begin{tabular}{|c|c|}
\hline Dobre prakse: & Slabe prakse: \\
\hline $\begin{array}{l}\text { - vzpostavitev krizne sobe Direktorata za obrambne } \\
\text { - zadeve; } \\
\text { maje so vedno dobro izvedene zaradi osebne } \\
\text { motiviranosti, dobre usposobljenosti, kolektivnega } \\
\text { - dobro funkcijsko in medsektorsko sodelovanje, ki } \\
\text { bi moralo biti sistemsko urejeno; } \\
\text { - častniki za povezavo; } \\
\text { - sodelovanje s stalnimi predstavništvi RS v tujini; } \\
\text { - oblikovanje skupnega portala, na primer »Pomlad } \\
2011 \text { «, »Acid«, ki omogoča hranjenje in analizo } \\
\text { informacij na enem mestu, vendar je to mogoče } \\
\text { le znotraj MO RS, in ne širše; } \\
\text { - dobro komuniciranje in izmenjava informacij na } \\
\text { taktični in operativni ravni; } \\
\text { - pregleda dnevnega dogajanja NCKU, kar } \\
\text { omogoča celovit pregled in obveščenost o poteku } \\
\text { aktivnosti; } \\
\text { - odziv nacionalnovarnostnega sistema na pojav } \\
\text { hibridnega vojskovanja je pospešil ustanovitev } \\
\text { skupine za kibernetsko delovanje znotraj SV; } \\
\text { - vzpostavitev videokonferenčnih povezav in sej. }\end{array}$ & $\begin{array}{l}\text { - nejasnosti glede razmejitev pristojnosti za } \\
\text { odločanje na politični in vojaški ravni; } \\
\text { - prepočasno sprejemanje ukrepov kriznega } \\
\text { odzivanja (Natovih in vladnih); } \\
\text { - neopredeljeni postopki štaba ob uvedbi kriznega } \\
\text { upravljanja (GŠSV nima jasno določenega nosilca } \\
\text { štabnega procesa niti nima svojega situacijskega } \\
\text { centra za zadovoljivo podporo in spremljanje } \\
\text { situacije); } \\
\text { - prepočasno kroženje informacij med političnim } \\
\text { odločanjem, strateško in izvedbeno ravnijo; } \\
\text { - komunikacijsko-informacijska podpora ne } \\
\text { omogoča prenosa tajnih podatkov med akterji, ni } \\
\text { povezljiva z Natovim sistemom; } \\
\text { - pomanjkanje ustreznih pravnih podlag za } \\
\text { delovanje SV znotraj kriznega upravljanja; } \\
\text { - organizacijsko-mobilizacijski razvoj ni ustrezen, } \\
\text { dopolnjevanje SV ob pojavu kriz je predolgotrajen } \\
\text { proces, dodatno dopolnjevanje SV je mogoče šele } \\
\text { ob uvedbi kriznih razmer; } \\
\text { - ni zagotovljenih prostorskih razmer, da bi GŠsV } \\
\text { deloval centralno - delovanje z mirnodobnih } \\
\text { lokacij se je izkazalo kot neustrezno in razpršeno. }\end{array}$ \\
\hline
\end{tabular}




\subsection{Analiza kriznega odzivanja SV v praksi}

\section{Žled 2014}

Zaradi razsežnosti naravne nesreče je bila aktivirana tudi SV, ki je vidno prispevala $\mathrm{k}$ reševanju krize in odpravljanju posledic ter normalizaciji stanja.

\begin{tabular}{|c|c|}
\hline Dobre prakse: & Slabe prakse: \\
\hline $\begin{array}{l}\text { - hitri odzivnost in sposobnost izvedbe (vojaškega) } \\
\text { procesa odločanja na taktični ravni ter } \\
\text { prevzemanje iniciative v primerjavi z drugimi } \\
\text { subjekti sistema ZRP sta prednosti vojske, ki sta v } \\
\text { praksi pogosto premalo uporabljeni; } \\
\text { - častniki za povezavo (v civilnem okolju in drugih } \\
\text { strukturah ZRP); } \\
\text { - usposobljenost in motiviranost pripadnikov SV; } \\
\text { - vključitev vojaških strokovnjakov v strukturo } \\
\text { kriznega odzivanja, predvsem v obliki delovanja } \\
\text { na terenu (psihologi, pravniki, veterinarji ipd.); } \\
\text { - zbiranje podatkov o stanju neposredno na terenu } \\
\text { (oblikovanje skupin za pridobivanje podatkov s } \\
\text { terena in dajanja pomoči prebivalstvu). }\end{array}$ & $\begin{array}{l}\text { - enote SV so bile pripravljene nekaj dni pred } \\
\text { aktivacijo, na teren so bile poslane šele četrti dan } \\
\text { po pojavu krize; } \\
\text { - v praksi na terenu ni vedno določen subjekt, ki bi } \\
\text { vodil koordinacijo med vsemi subjekti (problem } \\
\text { povezanosti in usklajenosti); } \\
\text { - ukazi nadrejenih so prihajali prepozno (problem } \\
\text { pravočasne priprave na nalogo); } \\
\text { - delovanje SV ne sme biti prepuščeno iniciativam } \\
\text { županov in odvisno od organiziranosti civilne } \\
\text { zaščite na lokalni ravni; } \\
\text { - pomanjkanje specifičnega strokovnega kadra (na } \\
\text { primer upravljavci motornih žag); } \\
\text { - posamezniki na terenu se hitro ujamejo, } \\
\text { usklajevanje delovanja v kriznih štabih pa ni } \\
\text { utečeno (slab odzivni čas); } \\
\text { - odsotnost enotnega komunikacijsko- } \\
\text { informacijskega sistema. }\end{array}$ \\
\hline
\end{tabular}

Vir: povzeto po Škerbinc idr., 2014, 83-86.

Kljub dobro opravljenem delu je glede na opravljeno analizo ostalo še veliko prostora za izboljšave, predvsem v smislu povečanja učinkovitosti in racionalizacije sistema kriznega upravljanja kot celovitega sistema, ki izrablja vse možnosti, ki jih ima na razpolago (tudi pri uporabi zmogljivosti SV). 


\section{Migrantska kriza 2015-2016}

V RS so se začeli procesi »operacije migrant«, ki bi jo lahko označili tudi kot krizno odzivanje. To potrjujeta tudi dopolnitev Zakona o obrambi in razširitev pooblastil SV s členom 37. a ob izrednih (kriznih - op. avtorja) razmerah na zaostreno varnostno situacijo $^{23}$. Dobre in slabe prakse so povzete na podlagi analize delovanja SV v podporo Policiji in iz izkušenj v operaciji migrant.

\begin{tabular}{|c|c|}
\hline Dobre prakse: & Slabe prakse: \\
\hline $\begin{array}{l}\text { - centralizirano vodenje (SV, MNZ, Civilna zaščita } \\
\text { (CZ)) vseh aktivnosti in nalog na enem mestu; } \\
\text { - priprava skupnega operativno-taktičnega načrta } \\
\text { sodelovanja SV in Policije; } \\
\text { - pravočasno napisana pravila delovanja SV v } \\
\text { podporo Policiji pri širšem varovanju državne } \\
\text { meje, ki jih je sprejela Vlada RS; } \\
\text { - častniki za povezavo v ZOC, pri Policiji in CZ; } \\
\text { - usklajevanje nalog, preneseno na ZOC, linija PINK } \\
\text { se je prilagajala glede na naloge; } \\
\text { - vzpostavitev operativnega (inženirskega) centra za } \\
\text { strokovno svetovanje in spremljanje situacije; } \\
\text { - vlogo koordinatorja dela na terenu prevzameta } \\
\text { nosilni brigadi (podpora CZ in Policiji), } \\
\text { sodelovanje s Policijo je bilo dobro, želja po } \\
\text { usklajenem delu velika; } \\
\text { - dnevni ukazi ZOC so bili prek častnikov za } \\
\text { povezavo usklajeni z nosilnimi enotami. }\end{array}$ & $\begin{array}{l}\text { - štabna organiziranost GŠSV in sestava sil, ki so } \\
\text { predvidene z obrambnimi mobilizacijskimi načrti, } \\
\text { nestalnost določenih štabnih organov in nosilcev } \\
\text { funkcijskih področij; } \\
\text { - različni sistemi PINK (Policija, SV, CZ); } \\
\text { - umeščenost ZOC se je izkazala za težavno v } \\
\text { strukturi PINK, lokacijska razdrobljenost GŠSV in } \\
\text { specialističnih enot (inženirskih, JRKBO ipd.) ne } \\
\text { omogoča optimalnega kriznega odzivanja; } \\
\text { - odziv PPRS ni dosegel pričakovanega; } \\
\text { - neustrezna zakonska urejenost področja kriznega } \\
\text { upravljanja in ad hoc delovanje; } \\
\text { - ni bilo skupnega usposabljanja s Policijo } \\
\text { za izvajanje skupnih nalog (slabost je bila } \\
\text { odpravljena šele, ko je bila zaznana); } \\
\text { - ni bilo zaznati preventivnega in obveščevalno- } \\
\text { informativnega delovanja pred krizo in po njej; } \\
\text { - slabo komuniciranje z javnostjo in obveščanje. }\end{array}$ \\
\hline
\end{tabular}

Obe opravljeni analizi izkušenj nakazujeta ugotovitev, ki jo je Kotnik $(2008,211)$ izpostavil že leta 2008, da je treba povečati in sistemsko izpopolniti vlogo SV V sistemu nacionalnega kriznega upravljanja, saj je učinek njenih zmogljivosti pri odpravljanju večine kriz in njihovih posledic nenadomestljiv.

\subsection{Ideja koncepta kriznega upravljanja SV}

Ideja koncepta kriznega upravljanja v SV je v organizacijskem in procesnem smislu oblikovana na podlagi teoretičnih in normativnih izhodišč, ugotovitev že opravljenih raziskav $^{24}$, primerjalnih analiz ter drugih dejstev, zapisanih v prispevku.

\section{Organizacijska struktura}

Pri vzpostavitvi učinkovitega kriznega upravljanja ne smemo zapostaviti pomena kriznega vodenja znotraj procesov upravljanja kriz. Pri vzpostavitvi koncepta KUV ${ }^{25}$ v SV bi bilo smiselno upoštevati ugotovitve Boin, Hart, Stern (2015, str. 1-18), in

\footnotetext{
${ }^{23}$ Ne moremo pa trditi, da je šlo za proces kriznega upravljanja, saj je skupna ugotovitev vseh, ki so proučevali operacijo migrant, da RS ni upoštevala zgodnjih znakov in groženj pred eskalacijo krize in je glavnino migrantskega vala pričakala nepripravljena.

${ }^{24}$ Na primer Malešič, 2008; Vuga, Ferlin, 2016; Prezelj, 2005.

${ }_{25}^{25}$ Termin, kot ga pri prenavljanju načina upravljanja kriz v RS uvajata tudi Vuga in Ferlin (2016).
} 
sicer, da imajo voditelji posebno odgovornost ukvarjanja s krizami v vseh njihovih fazah $^{26}$. Na ravni SV je ta organ odločanja ob pojavu kriz načelnik GŠSV ${ }^{27}$.

Naslednji ključni korak izhaja iz ugotovitev avtoric Vuga in Ferlin (2016, 7), ki ugotavljata, da imajo vse države (zajete $\mathrm{v}$ analizi vladne projektne skupine) usklajevalni organ, ki upravlja kompleksne krize. Tudi v SV bi bilo smiselno slediti tem ugotovitvam in pregledati obstoječe rešitve ter jih, kot smo že omenili, ob postavljanju nove strukture in obsega SV posodobiti, skladno s konceptom strukture KUV pri Vladi RS. Aktivnosti usklajevanja in zagotovitve ustrezne podpore pri odločanju v procesu kriznega upravljanja bi se morale z vidika hierarhičnosti in funkcionalnosti najprej ustrezno uravnotežiti med načelnikom GŠSV, načelnikom štaba GŠSV in poveljnikom Poveljstva sil SV. Znotraj kabineta načelnika GŠSV je treba na novo vzpostaviti funkcijo koordinatorja za strateške komunikacije (StratCom), dolžnost, ki bi morala biti stalna in formacijsko določena.

Načelnik štaba bi imel zaradi lažje operacionalizacije del možnost oblikovanja operativne skupine, nestalnega organa, ki bi se oblikoval po potrebi oziroma bi se zaradi izmenjave informacij in usposabljanja skliceval periodično tudi $\mathrm{v}$ miru. Skupino (na nacionalni ravni bi lahko to skupino primerjali s SSNAV) bi sestavljali strokovnjaki vseh glavnih funkcijskih področij GŠSV, strokovni organi, civilni strokovnjaki, podporne službe ipd. Med krizo bi skupina delovala z ene lokacije (takšna lokacija bi lahko bila z vidika funkcionalnosti bližina načelnika štaba GŠSV ali lokacija Poveljstva sil SV) ${ }^{28}$.

Nadalje je treba pri oblikovanju koncepta kriznega upravljanja temeljito razmisliti o naboru sil in zmogljivosti za ustrezno krizno upravljanje. Nujno bi bilo upoštevati dejstvo, da se ob spoprijemanju s krizami vedno srečujemo s kadrovskimi težavami (pomanjkanje kadra, neuspešnost vpoklica pogodbene rezerve ipd.). Poleg motiviranja pogodbene rezerve in pridobivanja novega kadra v vojaško organizacijo bi bilo smiselno razpravljati tudi o načinih in pogojih ponovne uvedbe služenja vojaškega roka ob trajnejših krizah, ki bi zahtevale množični vpoklic.

$\mathrm{Na}$ podlagi izvedenih analiz lahko izpostavimo, da lahko element izmenjave informacij, usklajevanja in poročanja, poleg formalnih voditeljev in odločevalcev, zelo učinkovito opravljajo častniki za povezavo. Čeprav ni nujno, da je ta funkcija stalna, bi morali biti častniki za opravljanje te funkcije v kriznih razmerah posebej usposobljeni že v mirnodobnem času. Prav tako bi bilo nujno, da SV imenuje

\footnotetext{
${ }^{26}$ Zaradi tega razčlenijo pet kritičnih strateških nalog kriznega vodenja: osmišljanje/opredelitev krize, sprejemanje odločitev, oblikovanje pomena krize, končanje krize in učenje iz naučenih lekcij (Boin, Hart, Stern, 2015, str. 1-18).

${ }^{27}$ Z vzpostavitvijo Poveljstva sil SV leta 2017 se lahko pričakuje, kot je to že bilo v preteklosti, da se bo del teh pristojnosti prenesel na poveljnika Poveljstva sil.

${ }^{28}$ Večina članov tako oblikovane operativne skupine bi v pripravljalnem času oblikovala začasno delovno skupino, ki bi pripravila podlago za delovanje sistema, spisala katalog zmogljivosti SV, proučila in posodobila ukrepe nacionalnovarnostnega sistema, ki se nanašajo na obrambno področje, pripravila predloge spremembe zakonodaje z obravnavanega področja, zapisala direktivo kriznega upravljanja ipd.
} 
stalnega predstavnika v procesu celotnega kriznega upravljanja v okviru NCKU, ne le pri zagotavljanju razmer za njegovo delovanje.

Pogosto se pozablja na navidezno stranske akterje v procesu upravljanja krize. V mednarodnem okolju se pogosto pozablja na vojaška predstavništva (VOPRE). Ta bi morala imeti znotraj procesa kriznega odločanja Nata in EU jasno določene vloge in naloge za aktivnejše sodelovanje pri kriznem upravljanju.

Na terenu je treba določiti subjekt, zadolžen za vodenje koordinacije med vsemi sodelujočimi. SV je, glede na mnenja mnogih strokovnjakov s tega področja (na primer Kotnik, 2005, Malešič, 2008, Škerbinc, 2014), edina sposobna na terenu organizirati operativni center za spremljanje situacije in koordinacijo vseh akterjev, zato bi bilo treba voditi politiko v tej smeri kot tudi v smeri povečanja vloge SV pri kriznem upravljanju, saj je po izkušnjah iz prakse vedno prepozno angažirana.

Skica 2: Predlog umestitve in prilagoditve koncepta kriznega upravljanja v SV

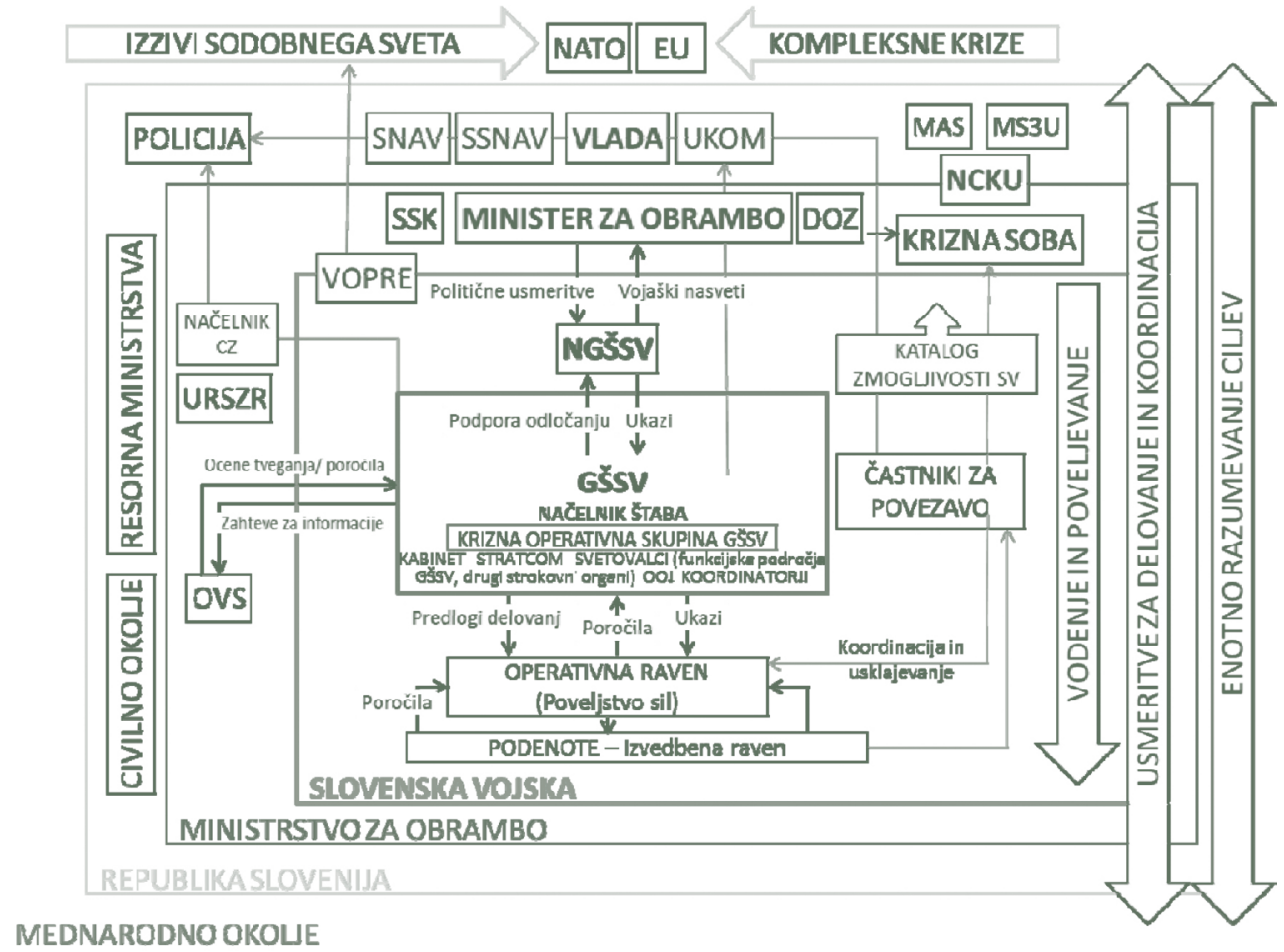

Na skici 2 je grafično predstavljen koncept kriznega upravljanja v SV. Pomembno je, da se lahko struktura povezuje z vsemi nacionalnimi in mednarodnimi elementi znotraj sistema na svoji ravni vodenja in poveljevanja, $\mathrm{v}$ okviru usmeritev in navodil 
političnih organov. Koncept kriznega upravljanja v SV bi moral biti umeščen prek načelnika GŠSV vertikalno k ministru za obrambo, saj, kot ugotavljata Vuga in Ferlin (2016), krize zahtevajo politično podporo in pretok informacij z odločevalne ravni na izvedbeno. Poleg zarisanih formalnih poti sodelovanja se na operativnotaktični ravni pričakuje intenzivno medinstitucionalno povezovanje, usklajeno prek posameznih koordinacijskih centrov do NCKU, ki poskrbi za ustrezno izvedbo oblike delovanja.

\section{Procesi}

Preden se oblikujeta oblika in način štabnega dela, je treba odpraviti nejasnosti glede razmejitev pristojnosti za odločanje na politični in vojaški ravni (kakšni sta vlogi ministrstva in SV, kdaj aktivirati zmogljivosti SV ipd.). Pri vzpostavljanju štabnih postopkov kriznega upravljanja bi bilo na strateški in operativni ravni smiselno uvesti Natov šestfazni postopek pristopa k reševanju kriz in znotraj njega umestiti nacionalne posebnosti. V sedanjem stanju, ko v SV na določenih ravneh velja petfazni proces vojaškega odločanja, nikakor ni mogoče uskladiti teh postopkov. Poleg tega je treba uskladiti tudi mehanizme kriznega odzivanja, saj je bilo ugotovljeno v analizah po vaji, da so različni in neusklajeni ter ne omogočajo pridobivanja skupne slike in usklajenega delovanja.

Postopek aktivacije SV (upoštevajoč ugotovitve avtoric Ferlin in Vuga, 2016) bi lahko začel minister za obrambo, po naročilu vlade oziroma ob aktiviranju NCKU prek stalnega člana SV. V nadaljevanju bi bilo treba oblikovati ustaljen sistem poročanja znotraj SV in navzven do vseh ravni ter pravno podlago delovanja $\mathrm{V}$ kriznih razmerah, ki bi bila hierarhično urejena in skladna s ključnimi področnimi nacionalnimi in mednarodnimi dokumenti (NCRSM, Lizbonska pogodba ipd.). Prepoznane rešitve, usklajene s procesi in postopki kriznega upravljana Nata in EU, bi bilo treba zapisati v normativni akt, ki bi imel pravnoformalno veljavo in bi ustrezal vsem predstavljenim merilom učinkovitega kriznega upravljanja.

V spopadanju s kompleksnimi krizami je ključno medresorsko in mednarodno sodelovanje. Razviti je treba povezovalne in koordinacijske mehanizme z MO in drugo nacionalno strukturo kriznega upravljanja (na primer policijo, civilno zaščito, kinologi ipd.), ki bodo usklajeni s postopki Nata in EU. Treba je paziti tudi na usklajenost organov, funkcij in postopkov kriznega upravljanja. Preglednica $1 \mathrm{v}$ nadaljevanju daje nekatera izhodišča za upoštevanje tega elementa, saj prikazuje področja odstopanja od urejenosti $\mathrm{v}$ Natu in EU ter hkrati predlaga ideje za uskladitev postopkov na različnih ravneh kriznega upravljanja, znotraj katerih deluje SV. V preglednici so v stolpcu Nato in EU zapisani organi, ki opravljajo določeno funkcijo, v stolpcih, ki opisujeta funkcijske organe RS in MO/SV, pa so zapisani tisti, ki naj bi po naši oceni v posodobljenem sistemu kriznega upravljanja izvajali neko funkcijo. 


\begin{tabular}{|c|c|c|c|c|c|}
\hline \multirow{11}{*}{$\begin{array}{r}\text { Preglednica 1: } \\
\text { Primerjava v } \\
\text { prispevku anali- } \\
\text { ziranih subjektov } \\
\text { kriznega } \\
\text { upravljanja }\end{array}$} & $\begin{array}{l}\text { Funkcije }^{1} \text { in } \\
\text { odločitve }\end{array}$ & Nato & EU & RS & $\mathrm{MO} / \mathrm{SV}$ \\
\hline & Funkcija odločanja & NAC & Svet EU & Vlada RS & Minister/NGŠSV \\
\hline & $\begin{array}{l}\text { Politično- } \\
\text { posvetovalna } \\
\text { funkcija }\end{array}$ & IS, MC, IMS & $\begin{array}{l}\text { EEAS in Oddelek } \\
\text { za krizno odzivanje } \\
\text { in operativno } \\
\text { načrtovanje }\end{array}$ & SNAV & $\begin{array}{l}\text { Kolegij ministra/ } \\
\text { politični } \\
\text { svetovalci } \\
\text { NGŠSV }\end{array}$ \\
\hline & $\begin{array}{l}\text { Funkcija } \\
\text { usklajevanja in } \\
\text { vodenja }\end{array}$ & $\begin{array}{l}\text { MC z IMS, } \\
\text { SACEUR s štabom }\end{array}$ & $\begin{array}{l}\text { Visoka } \\
\text { predstavnica EU }\end{array}$ & $\begin{array}{l}\text { Po pooblastilu } \\
\text { vlade SSNAV in } \\
\text { vodja SSNAV }\end{array}$ & $\begin{array}{l}\text { Koordinator } \\
\text { za operativno } \\
\text { skupino }\end{array}$ \\
\hline & $\begin{array}{l}\text { Funkcija } \\
\text { spremljanja } \\
\text { situacije in } \\
\text { usklajevanja }\end{array}$ & NIWS', SITCOM & Situational room & MS3U & $\begin{array}{l}\text { Operativna } \\
\text { skupina GŠSV } \\
\text { in OVS v } \\
\text { sodelovanju z J2 }\end{array}$ \\
\hline & $\begin{array}{l}\text { Funkcija analize, } \\
\text { predvidevanja in } \\
\text { načrtovanja }\end{array}$ & $\begin{array}{l}\text { NIWS in IMS, } \\
\text { Shape }\end{array}$ & EEAS, CMDP & $\begin{array}{l}\text { MAS, razširjena } \\
\text { stalna OpS }\end{array}$ & OVS \\
\hline & $\begin{array}{l}\text { Funkcija kriznega } \\
\text { komuniciranja }\end{array}$ & StratCom & $\begin{array}{l}\text { Urad visoke } \\
\text { predstavnice za } \\
\text { SZVP/SOVP }\end{array}$ & UKOM, SSNAV & $\begin{array}{l}\text { Združena SSKJ } \\
\text { OOJ v StratCom }\end{array}$ \\
\hline & $\begin{array}{l}\text { Funkcija pokrizne } \\
\text { analize }\end{array}$ & IS, MC, IMS & EEAS, CMDP & SSNAV & $\begin{array}{l}\text { Operativna } \\
\text { skupina GŠSV }\end{array}$ \\
\hline & Podporne funkcije & $\begin{array}{l}\text { Države članice, } \\
\text { civilni strokovnjaki }\end{array}$ & $\begin{array}{l}\text { Države članice, } \\
\text { funkcijski } \\
\text { strokovnjaki }\end{array}$ & $\begin{array}{l}\text { NCKU, posamezni } \\
\text { resorni elementi }\end{array}$ & Strokovne službe \\
\hline & $\begin{array}{l}\text { Prvi izdani } \\
\text { (opozorilni) } \\
\text { dokument }\end{array}$ & $\begin{array}{l}\text { IS - začetne } \\
\text { usmeritve }\end{array}$ & $\begin{array}{l}\text { Nasveti za } \\
\text { delovanje }\end{array}$ & $\begin{array}{l}\text { Sprejetje kriznih } \\
\text { ukrepov }\end{array}$ & $\begin{array}{l}\text { Ukaz za } \\
\text { delovanje }\end{array}$ \\
\hline & Izvedbeni organ & $\begin{array}{l}\text { Države članice s } \\
\text { svojimi OS }\end{array}$ & $\begin{array}{l}\text { Civilni strokovnjaki, } \\
\text { države članice, } \\
\text { evropske sile }\end{array}$ & $\begin{array}{l}\text { CZ, Policija, SV, } \\
\text { druge ustanove } \\
\text { NVS }\end{array}$ & CZ/SV \\
\hline
\end{tabular}

Iz preglednice je razvidno, da bi bilo treba poiskati primerljive entitete v SV, nacionalnem okolju in znotraj EU ter Nata. Tako bodo določeni nosilci posamezne faze procesa in ne bo prevelikega odstopanja na ravneh odločanja ter sledenja korakom procesa kriznega upravljanja. Prav tako bo jasneje, kateri organ je funkcijsko zavezan drugemu na višji ravni. Če za ilustracijo vzamemo NAC, kot najvišji politični organ Nata, lahko ugotovimo, da mu je na nacionalni ravni primerljivo

\footnotetext{
29 Za lažjo primerjavo so funkcije povzete po Vuga, Ferlin, 2016.

${ }^{30}$ Razlaga še nepredstavljenih kratic po zapisanem vrstnem redu v preglednici: NIWS - Natov obveščevalnoopozorilni sistem (Nato Intelligence Warning System), OVS - Obveščevalnovarnostna služba MO, $J 2$ - obveščevalna celica SV, OpS - Operativna skupina, SSK/OOJ - Služba za strateško komuniciranje MO/ Oddelek za odnose z javnostmi GŠSV, IS - Mednarodni štab (International Staff), CMDP - Direktorat za krizno upravljanje in načrtovanje (Crisis Management and Plans Directorate), OS - oborožene sile.
} 
MO (IS je primerljiv s kolegijem ministra za obrambo). Podobno je tudi z MC, ki je najvišji vojaški organ Nata, v RS mu je primerljiv GŠSV (IMS je primerljiv s štabom GŠSV). Na operativni ravni v Natu delujeta SACEUR in $S_{A C T}{ }^{31}, v$ SV pa je najvišji operativni organ poveljevanja Poveljstvo sil, ki se leta 2017 ponovno vzpostavlja.

Poleg vseh omenjenih novosti in izboljšav se ne sme pozabiti pozitivna praksa, ugotovljena na vajah in v resničnih situacijah delovanja v krizah. Njihove prednosti bi bilo treba primerno izkoriščati, zlasti pri posodabljanju konceptov in procesov $\mathrm{s}$ področja kriznega upravljanja (na primer prednosti krizne sobe, uporabnost častnikov za povezavo, skupnega portala, širjenje komuniciranja na nižjih ravneh, zavedanje kibernetske nevarnosti, iniciativnost in spremljanje situacije preden začne delovati vojska, zbiranje odzivov na terenu, skrb za zaščito svojih sil ipd.).

Sklep Pregled sistemov kriznega upravljanja v Natu in EU ter na nacionalni ravni, analize zakonodaje, vaj kriznega upravljanja ter delovanja v dveh realnih krizah potrjujejo izhodiščni trditvi iz uvoda. Z gotovostjo lahko sklepamo, da umestitev SV v sistem kriznega upravljanja na obrambnem področju ni celovita in da to posledično zmanjšuje njeno vlogo ter učinek pri delovanju in uresničevanju ciljev kriznega upravljanja pri odzivanju na krize. Ta spoznanja vodijo do sklepa, da morata posodobitev in izoblikovanje učinkovitega sistema kriznega upravljanja v SV slediti celovitim rešitvam in razvojni dinamiki tega področja na nacionalni ravni, vendar je treba nujno hkrati s tem tudi izoblikovati vojaško strokovno omizje, ki bo sposobno o teh sodobnih družbenih vprašanjih razpravljati ter, kar je še pomembnejše, posodobiti sistem, ki bo sposoben v vseh kriznih okoliščinah sodelovati pri upravljanju sodobnih in kompleksnih kriz.

Prispevek ne izpostavlja, da SV ni uspešna pri odzivanju na krize, saj ima tako zmogljivosti kot tudi znanje in izkušnje za intenzivnejše delovanje v kriznih razmerah. Kar dodatno vzbuja skrb in polemiko, je povezano s prestižno miselnostjo ključnih odločevalcev v kriznih razmerah, kar se posledično pogosto kaže v prepozni aktiviranosti SV oziroma v premajhnem obsegu. Njen uspeh je ravno zato velikokrat odvisen od nesistemskih rešitev, kot so motiviranost, samoiniciativnost, ad hoc usklajevanja in delovanja, ki pa ne omogočajo dolgoročnega delovanja $\mathrm{v}$ krizi, puščajo za seboj preveč odprtih vprašanj, izčrpavajo sistem in ne predlagajo celovitega pristopa. Ugotovitve nakazujejo, da bi bilo treba pri dopolnitvi oziroma oblikovanju sistema kriznega upravljanja v SV nameniti več pozornosti področju dopolnjevanja in kadrovskim rešitvam, sistemu vodenja in poveljevanja, razmejitvi odgovornosti in pristojnosti (predvsem na strateški in operativni ravni) ter usklajenemu delovanju, ki je ključno v tem procesu. Povečati bi bilo treba transparentnost in poskrbeti za boljšo obveščenost prebivalstva glede postopkov ravnanja ob večjih krizah in glede delovanja države. Nujno je oblikovati enoten sistem komuniciranja, ki bi temeljil na enotni strategiji komuniciranja ob kompleksnih krizah in ki bi bil sestavni del

\footnotetext{
${ }^{31}$ Primerljivost strukturiranosti Nata je treba obravnavati zgolj ilustrativno, saj je večnacionalne strukture težko neposredno primerjati z nacionalnimi.
} 
upravljanja informacij ter skladen z načeli Natovega »StratComa«. Treba je prenoviti in na novo določiti ukrepe kriznega odzivanja ter pripraviti enotno metodologijo za pokrizno analizo. Izoblikovati je treba mehanizme, ki bodo omogočili celovito ocenjevanje ogroženosti in identifikacijo področnih in kompleksnih kriz ter pripraviti manjkajoče načrte za odzivanje nanje. Aktivnosti za posodobitev in oblikovanje celovitega sistema kriznega upravljanja v SV bi bilo treba tudi časovno prilagoditi aktivnostim že potekajočega oblikovanja in uvajanja prenovljenega nacionalnega sistema KUV.

Raziskovalna spoznanja, strnjena s sintezo vseh teoretičnih in aplikativnih ugotovitev, izrazito poudarjajo nujnost in potrebo SV po posodobljenem ter celovitem sistemu kriznega upravljanja z jasno določenimi nalogami, ki bo v vseh fazah in segmentih delovanja usklajen z nacionalnim in Natovim kriznim upravljanjem ter kriznim upravljanjem EU. Predlagana ideja koncepta kriznega upravljanja SV daje v tem kontekstu celovit sistematični in shematski prikaz ureditve in umestitve področja kriznega upravljanja v SV, ki lahko kot dodatna strokovna podlaga koristi SV in MO pri iskanju učinkovitih rešitev na področju kriznega upravljanja.

Pri vsem tem se moramo zavedati, da se morajo pri posodabljanju področja kriznega upravljanja v SV upoštevati tudi sodobni varnostni izzivi, nova ogrožanja, kompleksnost situacij in razsežnost posledic. Krizo je namreč veliko bolje pričakati $\mathrm{v}$ pripravljenosti, kot da nas ujame nepripravljene.

\section{Literatura}

1. Analiza delovanja SV v podporo Policiji v zvezi z migrantsko problematiko za obdobje oktober 2015 do maj 2016. MO RS, 225-1/2016-959, 30. 6. 2016.

2. Blagonič, A., 2014. Usposabljanje za potrebe civilne obrambe, civilno kriznega upravljanja v okviru obrambnega sistema republike Slovenije. Fakulteta za državne in evropske študije, magistrska naloga.

3. Boin, Arjen, Hart, T., Paul, Stern, E., 2006. The Politics of Crisis Management: Public Leadership under Pressure, Cambridge University Press, Cambridge, United Kingdom.

4. Celovita analiza vodstvene obrambno zaščitne vaje v Ministrstvu za obrambo (POMLAD 2011). MO RS, 802-20/2011-94, 19. 5. 2011.

5. Crisis Management and Planning Directorate (CMPD), 2016. http://eeas.europa.eu/csdp/ structures-instruments-agencies/cmpd/index_en.htm (4. 8. 2016).

6. Crisis management. http://www.nato.int/cps/en/natolive/topics_49192.htm (20. 7. 2016).

7. Ekengren, M.; Groenleer, M., 2006. European Union crisis management: challenges for research and practice. International Journal of Emergency Management, vol. 3, Issue 1, str. 83-90.

8. EU External Action, Crisis response. 2016, http://eeas.europa.eu/crisis-response/index_ en.htm (3. 8. 2016).

9. Furlan, Branimir (in drugi), 2006. Vojaška doktrina, MO RS.

10. Kotnik-Dvojmoč, I., 2008. Oblikovanje sodobnega sistema kriznega upravljanja v Republiki Sloveniji s preoblikovanjem in nadgradnjo dosedanjih rešitev. Ujma: revija za vprašanja varstva pred naravnimi in drugimi nesrečami, št. 22 (2008), 209-218.

11. Malešič, M., (ur.), 2006: Komuniciranje v krizi. FDV, Ljubljana.

12. Malešič, M., 2008. Odzivanje na kompleksno varnostno krizo v Sloveniji: norma, struktura in funkcija. Teorija in praksa, let. 45 1/2, 113-127. 
13. Načrt vaj v obrambnem sistemu in sistemu varstva pred naravnimi in drugimi nesrečami $v$ letu 2016, Vlada RS.

14. Oddelek za obrambno krizno načrtovanje, 2016. http://intra.mors.si/index.php?id=2843 (25. 7. 2016).

15. Odlok o Svetu za nacionalno varnost (Odlok SNAV). Uradni list RS 70/2013.

16. Poročilo o Natovi vaji kriznega upravljanja CMX 11 v Republiki Sloveniji. Vlada RS, 87100-14/2014/8, 23. 12. 2014.

17. Poročilo o sodelovanju RS na Natovi vaji kriznega upravljanja CMX 12. MO RS, 8012/2012-47, 1. 2. 2013.

18. Poročilo o sodelovanju RS na vaji kriznega upravljanja CME12. MO RS, 801-1/2012-63, 18. 1. 2013.

19. Poročilo o sodelovanju RS na vaji kriznega upravljanja CME14. Vlada RS, 8710014/2014/8, 23. 12. 2014.

20. Poročilo o vaji CMX15 na Ministrstvu za obrambo (CMX15). MO RS, 801-2/2015-43, 30. 4. 2015.

21. Poročilo o vaji CME 11. Vlada RS, 87100-1/2011/27, 5. 4. 2012.

22. Predlog Zakon o obrambi, EVA 2016-1911-0001, 13. 4. 2016.

23. Prezelj, I., 2005. Nacionalni sistemi kriznega menedžmenta. FDV, Ljubljana.

24. Prezelj, Iztok, 2005. Tipične težave pri kriznem upravljanju. Ujma: revija za vprašanja varstva pred naravnimi in drugimi nesrečami, št. 19 (2005), 190-195.

25. Raduha, Nina, 2016. Krizno upravljanje na obrambnem področju s poudarkom v Slovenski vojski, zaključna naloga višjega štabnega tečaja.

26. Raduha, Nina, 2016. Natov koncept strateških komunikacij v RS s poudarkom na SV. Sodobni vojaški izzivi. December $2016-18 /$ št. 4.

27. Resolucija o strategiji nacionalne varnosti Republike Slovenije (ReSNV-1). Uradni list RS: $27 / 2010$.

28. Sklep Vlade Republike Slovenije, št. 810-02/2002-2 z dne 16. 1. 2003.

29. Strateški pregled obrambe, 2016. Ministrstvo za obrambo, Ljubljana.

30. Uredba o obrambnem načrtovanju,Uradni list RS, št. 51/13.

31. Uredba o organizaciji in delovanju Nacionalnega centra za krizno upravljanje. Uradni list RS, št. 9/06.

32. URSZR, 2014. Poročilo o posledicah poplav, visokega snega in žleda v Republiki Sloveniji med 30. januarjem in 9. februarjem. Slovenija v ledenih okovih-2014, izzivi in odzivi, zbornik, (ur. Malešič, Svete), FDV, 13-50.

33. Vlada RS, 2016. Posodobljen sistem kriznega upravljanja in vodenja. http://www.vlada. si/teme_in_projekti/projektna_pisarna/posodobljen_sistem_kriznega_upravljanja_in_ vodenja/ (29. 7. 2016).

34. Vuga-Beršnjak, Janja, Ferlin, Anica, 2016. Krizno upravljanje in vodenje v Republiki Sloveniji: predlog strukture KUV pri vladi RS. MO RS, Ljubljana.

35. Zaključno poročilo o vaji CMX 16. MO RS, 801-3/2015-117, 1. 4. 2016.

36. Zakon o obrambi (ZObr-UPB1). Uradni list RS, št. 103/2004-uradno prečiščeno besedilo. 


\section{ČETRTA GENERACIJA VOJSKOVANJA 3. del: NOV KONCEPT SV ZA DELOVANJE $\checkmark$ ČETRTI GENERACIJI VOJSKOVANJA}

\section{FOURTH GENERATION WARFARE Part 3: NEW SAF CONCEPT OF OPERATIONS IN FOURTH GENERATION WARFARE}

Povzetek V članku obravnavamo koncept lahke pehote in njeno vlogo v četrti generaciji vojskovanja, kot je bila opredeljena v prejšnjih prispevkih. Sodobno razumevanje lahke pehote je pogosto zavajajoče in neskladno z zgodovinskim razumevanjem pojma in koncepta lahke pehote. Podrobneje so predstavljene glavne značilnosti prave lahke pehote in zakaj te povsem ustrezajo potrebam četrte generacije vojskovanja. Ugotavljamo tudi, na kakšnih izkušnjah bi SV lahko utemeljevala svojo povezanost s konceptom klasične lahke pehote, in ponudimo enega izmed mogočih pristopov $\mathrm{k}$ spremembi organizacijske kulture, če bi ta želela prevzeti bistvene značilnosti lahke pehote. Nazadnje obravnavamo še nekaj elementov organizacije in strukture, ki bi v povezavi s konceptom lahke pehote ustrezali potrebam SV za delovanje v četrti generaciji vojskovanja.

Ključne Lahka pehota, frontna pehota, organizacijska kultura, četrta generacija besede vojskovanja.

Abstract The article presents the light infantry concept and its role in fourth generation warfare as defined in author's previous articles. Classical light infantry has a specific set of characteristics and the way NATO looks at it is not in accord with them and a historical perspective on light infantry. The article discusses in detail the key characteristics of light infantry and how they relate to fourth generation warfare. It also looks at how the SAF is related to the concept of light infantry, and how it should change its organizational culture if it wants to impregnate itself with light infantry mentality. Lastly, it looks at some elements linked to SAF organization and structure related to the concept of light infantry and fourth generation warfare.

Key words Light infantry, line infantry, organizational culture, fourth generation warfare. 
Uvod $» / . . . /$ The cold, brutal fact is that much present-day military power is simply irrelevant as an instrument for extending or defending political interests over most of the globe; /... When it comes to preventing acts of terrorism closer to home, the military services and their arms - fighter bombers, tanks, armored personnel carriers, etc. are even less useful.« (van Creveld, 1991, str. 27) ${ }^{1}$

Do zdaj smo lahko ugotovili, da bodo za uspešno delovanje v četrti generaciji vojskovanja $(4 \mathrm{GW})$ nujne resne spremembe organizacijske kulture ${ }^{2}$ na ravni celotnega nacionalnovarnostnega sistema, sicer tvegamo, da bomo nerelevantni, ne le znotraj zavezništva, temveč tudi pri soočanju z grožnjami, ki jih prinaša vojna četrte generacije.

Oborožene sile bodo morale narediti nekaj najtežjih korakov, pri tem bo moralo vodstvo najprej postaviti jasno definirane okvire nujnih sprememb. Tudi če so imela vodstva Slovenske vojske že v preteklosti iskrene namene po resnični transformaciji vojske v sodobno, profesionalno in na nove izzive pripravljeno silo, je treba stvarno ugotoviti, da v svojih namenih niso bila uspešna. Tega ni mogoče zanikati. Poročila vrhovnemu poveljniku o pripravljenosti $\mathrm{SV}$ to neizpodbitno dokazujejo. ${ }^{3} \mathrm{Ob}$ tem menimo, da je organizacijska kultura v SV spremembam izrazito nenaklonjena. ${ }^{4}$

V tem prispevku se bomo osredotočili na spremembe, ki so po našem mnenju nujne, da bi se vojske lahko spopadale s širokim spektrom groženj, ki jih prinaša četrta generacija vojskovanja. Menimo, da je pravilen pristop h konceptu lahke pehote ena izmed možnosti, kako oborožene sile preoblikovati v silo, sposobno spoprijemanja z vsem, kar to vojskovanje prinaša. Zavedamo se, da ima zamisel veliko gorečih nasprotnikov, prepričani pa smo, da ta nasprotovanja izhajajo predvsem iz nerazumevanja in nepoznavanja tega, kaj je prava organizacijska kultura lahke pehote. Zato menimo, da je najprej treba jasno opredeliti in razumeti bistvo lahke

\footnotetext{
»Mrzla, kruta resnica je, da je večina današnje vojaške moči preprosto irelevantna kot orodje projekcije ali obrambe političnih interesov po svetu. /.../ Ko gre za preprečevanje terorističnih dejanj doma, so zvrsti in njihovi rodovi - lovski bombniki, tanki, oklepni transporterji - še manj uporabni.«

2 Organizacijska kultura je sestavljena iz treh elementov, in sicer artefaktov, vrednot in prepričanj, ter temeljnih predpostavk. Pri tem so artefakti to, kar je na zunaj vidno, pri vojski so to npr. uniforme, bojni prapori in bojna sredstva. Vrednote in prepričanja obstajajo na dveh ravneh, in sicer to, kar je kot vrednota deklarirano, in to, kar je kot vrednota resnično razumljeno (prepričanje). Zaželeno bi bilo, da je to dvoje usklajeno, pa vendar ni vedno tako. In ne nazadnje so tu temeljne predpostavke, ki predstavljajo najpogosteje nezavedno podlago, na kateri je zgrajena organizacijska kultura.

3 http://www.delo.si/novice/politika/ocena-pripravljenosti-sv-slabsa-kot-leto-prej.html http://www.up-rs.si/up-rs/uprs.nsf/objave/730A776D0942B9BEC1257E54003EDE90?OpenDocument http://www.24ur.com/novice/slovenija/pahor-slovenski-vojski-podal-nezadostno-oceno.html

Poročila o pripravljenosti SV že več let zapored kažejo njeno nezadostno pripravljenost za izvrševanje najpomembnejših zakonsko določenih nalog (ZObr, 37 člen). Iz sporočil za javnost lahko sklepamo, da je glavni vzrok pomanjkanje finančnih sredstev. Menimo, da je to zavajajoče. Finančni viri so seveda pomembni in brez njih se sistem težko razvija, toda za spremembe v sistemu niso bistveni. Bistveno je razumevanje varnostnega okolja in kulturnih, organizacijskih, strukturnih in drugih sprememb, potrebnih za uspeh v novem varnostnem okolju. Za uresničenje sprememb so bistveni želja, sposobnost in znanje.

${ }^{4}$ Da bi to lahko potrdili, bi bila nujna raziskava organizacijske kulture in njene naklonjenosti spremembam. Dokler takšne raziskave ni, gre zgolj za avtorjeva osebna občutja in opažanja, pridobljena z metodo udeležbe.
} 
pehote. Predvsem je treba povedati, da lahka pehota, ki bi bila učinkovita v četrti generaciji vojskovanja, ni enakovredna temu, kar zavezništvo razume pod tem pojmom, ali temu, kar je bila slovenska TO leta 1991. Pogledali bomo, kaj je treba spremeniti v vojaškem izobraževanju in usposabljanju, da bi lahko oborožene sile preoblikovali v lahko pehoto, kar je izrednega pomena, saj narekuje formalnopravne rešitve, ki opredeljujejo usposabljanje v miru. Brez njihove pravilne opredelitve oboroženih sil ne bomo nikoli pravilno preoblikovali. Spremembe v obsegu in strukturi so manj pomembne kot transformacija v kulturi organizacije, ki mora biti nujno formalnopravno podprta, sicer je obsojena na neuspeh. Nazadnje bomo podali nekaj pogledov na obseg in strukturo SV, temelječih na konceptu lahke pehote.

\section{KONCEPT LAHKE PEHOTE}

\subsection{Lahka pehota proti frontni pehoti}

Po mnenju nekaterih strokovnjakov, pa tudi častnikov SV, naj bi s preoblikovanjem leta 2012 SV dobila značaj lahke pehote. Menimo, da je to daleč od resnice. Polki SV in vojska kot celota niso lahka pehota in to še dolgo ne bodo, vendar zaradi povezave $\mathrm{s}$ pojmom lahke pehote (angl. light infantry) in nepoznavanja zgodovinskih dejstev $\mathrm{v}$ njenem razvoju tudi v strokovni javnosti vlada precejšnja zmeda v razumevanju tega pojma. Dodatno zmedo je vnesel še Nato s svojo klasifikacijo pehote, kot je zapisana v dokumentu Capability Codes and Statements (CC\&S). Nato je že v tem dokumentu poznal pojem light infantry, se nato z novejšo opredelitvijo iz leta 2013 od njega oddaljil in govoril o motorizirani pehoti, da bi z najnovejšo klasifikacijo iz leta 2016 ponovno govoril o light infantry kot posebnem tipu pehotnih enot. Poglede na pojem lahke pehote bi lahko razdelili na dve skupini. V prvi je Natovo oziroma ameriško razumevanje, povezano s konceptom teže in organizacije, posebno tiste, v kateri ni težke opreme, kar ji omogoča veliko strateško mobilnost in odzivnost. V taktičnem smislu pa deluje kot vsaka druga izkrcana pehota. To razumevanje se bistveno razlikuje od druge skupine, ki lahkost razume v odnosu do bojevanja, specifičnega taktičnega sloga in raznolikosti v operativni uporabnosti (Lind \& Thiele, 2015).

Razlikovanje med tako imenovano frontno (angl. line) in lahko (angl. light) pehoto najdemo že v stari Grčiji, v kateri je frontno pehoto predstavljal palax težko oklepljenih in opremljenih pešakov, katerih učinkovitost je temeljila na drilu, množici in šoku. Ob tem je vojsko starih Grkov sestavljala tudi precej obsežna pomožna (lahka) pehota, ki je skrbela za zaščito bokov in je temeljila na hitrosti ter kovinskem orožju ${ }^{5}$. Ta koncept je pozneje izrabila tudi rimska legija, ki je uporabljala lahko pomožno pehoto $\mathrm{v}$ podpori težkim kohortam frontne pehote. $\mathrm{V}$ srednjem veku je bojišče obvladovala konjenica in šele $\mathrm{v} 16$. in 17 . stoletju je počasi ponovno prevladala pehota. V 18. stoletju se je lahka pehota nato začela pojavljati v evropskih vojskah v obliki francoskih chasseur's, pruskih Jaeger- in avstrijskih Grenzer-polkov (Lind \& Thiele, 2015). Te enote so se bistveno razlikovale od strogo discipliniranih enot

5 Lok, kopje, prača. 
težke pehote, saj so bile hitre, okretne in iznajdljive, predvsem pa so lahko delovale neodvisno od logistike glavnine vojske. V obdobju Napoleonovih vojn (1790-1815) se je evropska lahka pehota izjemno razvila, tako da je vključevala lahko artilerijo in lahko konjenico, zato je na bojišču dobivala vse večjo vlogo: kritje umika in napredovanja glavnine, zavajanje nasprotnika, izvidovanje itn. Njena prisotnost je bila občutna pri Ulmu, Jeni, Auerstedtu in med vso Welingtonovo kampanjo v Španiji (McMichael, 1987). S takšno lahko pehoto so se evropska kraljestva borila tudi v Ameriki, zelo zanimive so izkušnje stotnika Johana Ewalda ${ }^{6}$ Evropska kraljestva 18. in 19. stoletja so lahko pehoto dojemala kot nujen način bojevanja, čeprav nevreden pravega vojaka, predvsem zaradi posebnega taktičnega sloga in organizacijske sproščenosti, ki nista ustrezala strogi urejenosti bojišča 18. in 19. stoletja (Selig \& Skaggs, 1991).

Klasični pogled lahko pehoto najprej dojema kot stanje duha in šele nato kot produkt organizacije. Poseben pristop k bojevanju ustvari tudi poseben slog taktike, ki ga običajno ne najdemo v konvencionalni pehoti (McMichael, 1987). Sodoben koncept lahke pehote je razvila vzhodnjaška vojaška teorija 20. stoletja, soočena s tehnološko in materialno premočjo zahodnih vojsk. Med drugo svetovno vojno je imela Japonska taktično najbolje usposobljeno lahko pehoto na svetu, v korejski vojni je Kitajska s svojo pehoto dosegla ravnotežje v boju s tehnično in materialno zmožnejšimi silami OZN (pod vodstvom ZDA), v Vietnamu so ZDA kljub svoji tehnični in materialni moči izgubile, v iraško-iranski vojni smo bili priča spopadu tehnologije s taktiko, brez izrazite premoči ene ali druge strani. Vendar se moramo zavedati, da taktična odličnost ni dovolj proti nasprotniku, ki je pripravljen v spopad vložiti nesorazmerne materialne in človeške vire ${ }^{7}$ in je na operativni ravni vsaj enakovreden, če ne celo boljši ${ }^{8}$ (Poole, 2001).

Klasična lahka pehota ima nekaj resnih omejitev, ki jih moramo razumeti, da bi koncept pravilno prenesli na celotne oborožene sile. Lahka pehota kljub svoji vsestranskosti in prilagodljivosti ni sila za vsako priložnost ali situacijo. V visoko intenzivnem konvencionalnem spopadu ima zelo omejeno uporabnost, saj ji manjka ognjene moči in bojne ter logistične podpore za dolgotrajni bojni stik. Izrazito je ranljiva na artilerijski in letalski ogenj. Neprimerna je za dolgotrajne defenzivne operacije, saj nima logistične infrastrukture za njihovo izvedbo. Manjka ji ognjene moči in vzdržljivosti za napad na utrjene točke, razen kadar ji uspe doseči popolno presenečenje. Na odprtem terenu je zelo občutljiva na hiter manever in večjo ognjeno moč (McMichael, 1987).

\footnotetext{
${ }^{6}$ Treatise on Partisan Warfare (Abhandlung über den kleinen Krieg), prevedeno tudi v angleški jezik, $s$ spremljajočim esejem. V delu je stotnik Ewald J. opisal svoje izkušnje z delovanjem lahke pehote med ameriško vojno za neodvisnost.

Tako Japonci kljub nesporni taktični odličnosti niso zmogli ustaviti napredovanja zahodnih zaveznikov, ki so jih $v$ Indiji številčno osemkrat prekašali (Poole, 2001, str. 6).

${ }^{8}$ Enako Japonci v Mandžuriji niso zmogli ustaviti ruskega oklepnega manevra na operativni ravni (Poole, 2001, str. 5).
} 
Takšno bi torej moralo biti pravilno razumevanje klasične lahke pehote v odnosu do drugih frontnih tipov pehote ${ }^{9}$. Menimo, da sodobno okolje četrte generacije vojskovanja zaradi širokega spektra groženj postavlja koncept klasične lahke pehote v ospredje. Ne zaradi strateške mobilnosti ali (lahke) organizacijske strukture, temveč zaradi organizacijske kulture, ki ustvarja poseben pristop do vojskovanja.

\subsection{Ključne značilnosti lahke pehote}

Značilnosti lahke pehote niso izključno njene in jih lahko v številnih primerih najdemo tudi $\mathrm{v}$ frontni pehoti. Toda bistvene razlike obstajajo, čeprav jih je težko opaziti, ker so sestavni del nevidnega - namreč miselnosti lahkega pehotnika. Različni avtorji (Ewald, Lind, McMichael, Poole in Thiele) značilnosti lahke pehote različno poimenujejo in rangirajo, v splošnem pa lahko izluščimo štiri osrednje značilnosti. Najpomembnejša je samozadostnost (angl. self-reliance), ki je bistvo etosa lahke pehote in izvir, iz katerega se napajajo vse druge njene značilnosti. Samozadostnost se izraža v intelektualni prilagodljivosti in fizični ter psihični trdnosti. Pripadniki lahke pehote so navajeni na asketske razmere in lahko delujejo tudi brez »ugodnosti«, ki jih frontna pehota dojema kot nujne, ter niso psihološko vezani na logistično podporo, predvsem pa ne odnehajo in skušajo do zadnjega obrniti situacijo v svojo korist.

Pristop samozadostnosti omogoča in hkrati zahteva mojstrsko obvladovanje in razumevanje okolja, v katerem delujejo. Ne glede na teren in klimatske razmere je okolje njihov zaveznik, ki jim daje varnost in udobje. Ker so izjemno prilagodljive, te enote obvladujejo teren in ga znajo preoblikovati v taktično prednost. Ker teren in klimo sprejemajo kot naravnega zaveznika, je zanje značilna neprimerljiva taktična gibljivost na zahtevnem zemljišču. Nič ni namreč bolj gibljivega, kot je lahka pehota v gozdu, džungli, hribovitem in goratem svetu ali urbanem okolju.

Obvladovanje zemljišča in samozadostnostvodita knaslednji značilnosti lahke pehote, k vsestranskosti. Ker se je sposobna hitro prilagoditi zemljišču in tipu operacije, je nenadne spremembe v načrtih nikoli ne najdejo nepripravljene. Enote lahke pehote lahko delujejo samostojno ali znotraj večje enote, z elementi bojne podpore ali brez njih. Vsestranskost se kaže tudi v nagnjenosti k improvizaciji in inovacijam. Ker lahka pehota ni strogo vezana na doktrino, lažje razvije nove taktike, inovativno uporablja svojo opremo in se ne obotavlja pri uporabi sovražnikove opreme in virov, ko je treba. Vedno ostaja odprta za nove zamisli, tehnologijo in oborožitev. Bistveno je ohranjanje prilagodljivega odnosa do bojišča.

Vse te značilnosti $\mathrm{v}$ enoti povzročajo zelo visoko zavest kolektiva - esprit de corps. Pripadniki lahke pehote se zavedajo, da so drugačni, ponosni so na to, da delujejo v najzahtevnejšem okolju in najzahtevnejših nalogah. Štejejo se, da so boljši od povprečnega frontnega vojaka in to tudi so. Treba se je zavedati, da se te značilnosti ne razvijejo same po sebi, temveč morajo biti rezultat zahtevnega

9 Glede na staro in novo klasifikacijo pehote v Natu. 
usposabljanja, ustreznega vodenja in opravljenih nalog. Sploh ne smejo biti rezultat česar koli drugega. Poleg teh štirih glavnih značilnosti lahko pehoto determinira tudi poseben odnos do tehnologije, pridobivanja informacij, bojne podpore, logistike in vodstvenega kadra.

Tehnologija ni odločujoči dejavnik delovanja lahke pehote. Tudi če neka tehnologija obstaja, to še ne pomeni, da bo kakor koli prispevala k delovanju lahke pehote. Ognjena podpora s posrednimi ognji za zahteve lahke pehote ne bo vedno učinkovita, prav tako je neuporabna visokotehnološka oprema, ki je pretežka za prenašanje po zahtevnem zemljišču in ne dovoljuje grobega ravnanja. Glavno pravilo pri uporabi novih tehnologij v lahki pehoti je, da je treba te prilagoditi njej in ne obratno. Nikakor pa tehnologija ne sme vplivati na temeljno značilnost lahke pehote-samozadostnost.

Pridobivanje točnih in pravočasnih obveščevalnih informacij je odločilnega pomena za delovanje lahke pehote. Večino uporabnih informacij pridobi sama. Glavni način zbiranja informacij je patruljiranje, ji pa seveda koristijo tudi vsi drugi obveščevalni viri, ne le vojaški, temveč tudi policijski in civilni, zato je ustrezno usklajevanje na tem področju nujno.

Pomemben dejavnik za lahko pehoto je tudi logistika. Logistično načrtovanje vpliva na načrtovanje njenega delovanja, vendar ga ne obvladuje. Da bi se oskrbela, lahka pehota čim bolj izkorišča lokalne vire. Teža individualne opreme je popolnoma prilagojena dejavnikom naloge, sovražnika, zemljišča in vremena. V splošnem velja, da posameznik nosi samo to, kar je nujno ${ }^{10}$. Na tem področju sta seveda zelo dobrodošla sodobna tehnologija in napredek v materialih ter izdelavi prehrambnih izdelkov. Uporaba helikopterja omogoča lahki pehoti samostojno delovanje na večjih razdaljah, daleč od logističnih baz.

Vodje v lahki pehoti so običajno inovativni, prilagodljivi in psihološko trdni. Prenašajo enaka bremena kot preostanek moštva in so zato prav tako dobro telesno pripravljeni in živijo načela samozadostnosti. Vodijo z zgledom in kažejo iskreno skrb za dobrobit svojega moštva, pri čemer ga nikakor ne razvajajo ${ }^{11}$. Predvsem pa ne skrivajo informacij pred njim, temveč skrbijo, da so soborci dobro obveščeni o taktični situaciji in svoji vlogi v njej. Seveda vse te lastnosti najdemo tudi med vodji v drugih tipih pehote in čeprav se vodje v lahki pehoti zdijo nekoliko neortodoksni, je večina, če že ne vsi, enako dobra kot vodje v konvencionalnih enotah.

Lahka pehota se res zanaša predvsem na organsko oborožitev, to pa ne pomeni, da elementi bojne podpore drugih rodov niso dobrodošli ali celo nujni. Predvsem takrat, ko se lahka pehota uporablja za konvencionalne ofenzivne in defenzivne

\footnotetext{
${ }^{10}$ Kaj je nujno, je lahko razumljeno zelo različno, zato imajo tu poglavitno vlogo podčastniki in nižji častniki, ki morajo brezobzirno omejevati to, kar vojaki nalagajo v svoje nahrbtnike. Izkušnje seveda pomagajo, toda vodje morajo nenehno preverjati in prilagajati težo opreme.

${ }^{\prime \prime}$ Kar preprosto pomeni, da bodo naredili vse za čimprejšnjo evakuacijo ranjenih, hkrati pa ne bodo oklevali podaljšati patrulje ali zasede za nekaj dni, če bo imelo to taktični smisel.
} 
naloge. Močna artilerijska podpora in čim več inženirske podpore sta absolutno nujni, ko lahka pehota opravlja klasične defenzivne naloge. Pogosto je smiselno lahko pehoto okrepiti z lahkim oklepom, saj ji to omogoča mobilnost na večjih razdaljah in protioklepne zmogljivosti ter zmogljivost uničevanja utrjenih točk $\mathrm{s}$ težjo oborožitvijo vozil.

Iz poglavitnih značilnosti lahke pehote in njenega odnosa do pomembnih dejavnikov vojskovanja lahko razberemo, da to niso stvari, ki bi bile ekskluzivno povezane z delovanjem lahke pehote. Menimo, da so predvsem štiri ključne značilnosti lahke pehote in njen odnos do voditeljstva to, kar predstavlja bistvo njene organizacijske kulture, prilagodimo pa jih lahko prav vsem tipom pehote. Odnos do tehnologije, bojne podpore, obveščevalne zagotovitve in logistike pa je povezan s posebno vlogo in nalogo različnih tipov pehote ali rodu oboroženih sil v četrti generaciji vojskovanja. $^{12}$

\subsection{Lahka pehota kot odgovor na četrto generacijo vojskovanja}

Četrto generacijo vojskovanja razumemo kot hibridno vojskovanje visoke in nizke intenzivnosti. To je vojskovanje, $\mathrm{v}$ katerem se prepletajo konvencionalne sile in tehnologija z nedržavnimi akterji, kriminalnimi skupinami, delovanjem specialnih sil, informacijskim delovanjem, kibernetskim napadi in drugimi sredstvi asimetričnega vojskovanja.

V teh razmerah sta miselnost lahke pehote in njen pristop do bojevanja, ki ga odlikuje vsestranskost v delovanju, najprimernejša za spopadanje s sovražniki. Menimo, da je miselnost lahke pehote univerzalno uporabna - tudi v motorizirani, mehanizirani in drugi frontni pehoti, artileriji, inženirstvu, kibernetski obrambi in drugih rodovih. Seveda sta lahko znotraj hibridnega vojskovanja intenzivnost in tehnološka raven vojskovanja izjemno različni, kar pa ne pomeni, da je zaradi te različnosti treba vedno znova iskati nov miselni okvir vodenja vojn in vojskovanja. Tak okvir, ki zahteva sposobnost kritične presoje, informirano odločanje in sprejemanje hitrih odločitev (pravilnih), je skupen vsem oblikam hibridnega vojskovanja v četrti generaciji vojskovanja.

Spoprijemanje s četrto generacijo vojskovanja na ravni vodenja vojne zahteva tako obvladovanje tretje manevrske generacije vojskovanja kot miselni okvir, ki razume prave cilje nasprotnika in omogoča pravilne odzive nanj. Na operativni in taktični ravni je lahka pehota tista, ki najbolje odgovarja na večino groženj. Večino groženj v njej namreč predstavlja ravno sovražnik, ki kaže vse lastnosti lahke pehote. Ker celoten spekter vojskovanja v četrti generaciji vključuje tudi težke konvencionalne sile, je nujno zavedanje, da lahka pehota deluje v ciklu štirih korakov: razpršitev, orientacija, koncentracija in akcija (Lind \& Thiele, 2015). Tako je lahko uspešna tudi

\footnotetext{
12 Vezanost mehanizirane pehote na logistično podporo je razumljivo tesnejša kot vezanost kibernetske komponente na sodobno tehnologijo.
} 
v boju z močnejšim konvencionalnim sovražnikom, ko z uporabo taktike infiltracije skuša sovražnika najprej presenetiti in nato premagati v boju na kratke razdalje.

Napačno bi bilo predpostavljati, da zgolj in samo lahka pehota pomeni odgovor na grožnje v četrti generaciji vojskovanja. Ravno nasprotno, še vedno so zelo pomembni tudi mehanizirane sile, artilerija, inženirstvo in drugi rodovi ter službe oboroženih sil, vključno z izjemno pomembnim informacijsko-kibernetskim elementom. Menimo le, da bi bilo treba tudi vse preostale elemente oboroženih sil prepojiti z miselnostjo in organizacijsko kulturo lahke pehote.

\section{SLOVENSKA VOJSKA IN ODGOVOR NA ČETRTO GENERACIJO VOJSKOVANJA}

»Without changing our patterns of thought, we will not be able to solve the problems we created with our current patterns of thought. $\ll^{13}$ (Albert Einstein)

Zgodovinsko gledano imamo Slovenci nekaj mešanih izkušenj z lahko pehoto. Vendar je vse te formacije treba jemati s previdnostjo, ko iščemo primerjave s pravo lahko pehoto. Večinoma so bile te formacije lahke kot Nato danes razume lahko pehoto, kar pa, kot smo že pokazali, ni njena prava odlika.

Oddelki generala Maistra so nastali z razpadom avstro-ogrske vojske ob koncu prve svetovne vojne in so bili v doktrinarnem, organizacijskem in taktičnem smislu njeni nasledniki. Sploh pa niso obstajali dovolj dolgo, da bi se lahko razvili v kaj več. Slovensko domobranstvo je bilo pomožna formacija vojaško-policijskih sil nemške okupacijske vojske na ozemlju Slovenije in je dosledno sledilo doktrini, izobraževanju in usposabljanju nemških sil v drugi svetovni vojni. Udarni domobranski bataljoni so bili nedvomno sposobna vojaška sila in še najbližje tretji generaciji oboroženih sil. Teritorialna obramba RS je bila sestavni del oboroženih sil SFRJ in njenega koncepta splošne ljudske obrambe. Kot tako bi jo težko šteli za pravo predstavnico lahke pehote. Doktrinarno je namreč sledila JLA in tudi njen starešinski kader je bil rezultat sistema izobraževanja in usposabljanja JLA, ki ni bil nujno slab, a se je na koncu izkazala kot tipična predstavnica druge generacije vojsk. Nedvomno je TO opravila pomembno vlogo v osamosvojitveni vojni, ki bi jo po našem mnenju lahko jemali kot zgled vodenja vojne četrte generacije - a zgolj na ravni vodenja vojne. Govoriti o TO kot modelu lahke pehote za četrto generacijo vojskovanja bi bilo narobe in škodljivo, saj za to ni imela ustrezne miselnosti, sistema izobraževanja in usposabljanja ter predvsem starešinskega kadra.

Morda je le partizanska vojska spadala v kategorijo lahke pehote. Kot tipična gverilska vojska niti nima druge izbire, kot uveljaviti koncept samozadostnosti, askeze, obvladovanja zemljišča, prilagodljivosti, operativne vsestranskosti in

\footnotetext{
${ }_{13}$ »Brez spremembe naših trenutnih vzorcev razmišljanja ne bomo nikoli sposobni rešiti težav, ki smo jih ustvarili prav s temi vzorci razmišljanja."
} 
visokega esprit de corps. Če natančneje pogledamo vse značilnosti lahke pehote in njen poseben odnos do bojne podpore, logistike, obveščevalnega delovanja, tehnologije in vodenja, vidimo, da je slovenska partizanska vojska še najboljši približek lahke pehote.

Danes polki SV ne spadajo v Natovo kategorijo lahke pehote. Ta namreč predvideva uporabo vozil z oklepno zaščito Level 1, STANAG 4569. Pehotni polki SV pa vozil praktično nimajo. Sicer v Natu in drugod najdemo prave primere lahke pehote, med katere nedvomno spadajo izraelske in britanske padalske enote (Lind in Thiele, 2015). Da bi polke SV lahko primerjali s temi enotami, ne more biti niti govora. Njihovi standardi izobraževanja in usposabljanja so za polke SV nedosegljivi.

Kot že rečeno, bi bilo napačno lahko pehoto povezovati z lahko oklepno zaščito niti je ne bi smeli razumeti kot zmogljivost s posebnimi selekcijskimi standardi na meji specialnih sil (McMichael, 1987). Tudi če lahka pehota potrebuje zahteven program usposabljanja in odlično vodenje, to ne pomeni, da morajo biti njeni vojaki izbrani s posebnimi selekcijskimi postopki, kakršne poznajo v specialnih silah.

Za delovanje oboroženih sil je bistvenega pomena častniški zbor, ki je nosilec kakršnih koli organizacijskih in kulturnih sprememb. Če torej želimo vzpostaviti oborožene sile na temelju lahke pehote, moramo najprej vzpostaviti ustrezen poklicni sistem izobraževanja in usposabljanja častniškega zbora.

\subsection{Izobraževanje}

Za uspeh v četrti generaciji vojskovanja je bistvena široka razgledanost vodij na vseh ravneh. Kot je dejal že Johan Ewald, »/.../ mora v vojni častnik v lahki pehoti na najnižji ravni početi to, kar general počne na visoki ravni« (Ewald v Selig \& Skags, 1991, str. 64). Da bi to lahko počeli, je treba vodje že v miru ustrezno pripravljati na to.

SV mora postati učeča se organizacija, ki bo gojila in nagrajevala prilagodljivost, inovativnost, kritično razmišljanje, pobudo in samodisciplino. Kultura, ki jo vojska goji v svojem starešinskem zboru, mora biti holistična, usmerjena v profesionalno služenje družbi. Treba je oblikovati starešinski zbor, ki bo v službi družbe kot celote, na to podlago pa dodati »združena« oziroma medrodovsko orientacijo in etos. Šele nato se lahko mladim vodjem začnejo dodajati specializacije, ki bodo definirale individualne kariere (rodovsko kulturo, kulturo posameznega bojiščnega sistema, konvencionalno ali nekonvencionalno kulturo itn.) (Vandergriff, 2006, str. 53).

Prilagodljivost in inovativnost častniškega in podčastniškega kadra sta ključni lastnosti za delovanje v razmerah, ki jih pogojuje četrta generacija vojskovanja. Prilagodljivost se kaže v sposobnosti na hitro prilagajanje različnim situacijam ${ }^{14}$

\footnotetext{
${ }_{14}$ Američani v svoji doktrini govorijo o tako imenovani vojni treh ulic (angl. three block war), pri čemer je treba $v$ prvi voditi konvencionalni spopad, v sosednji protiterorizem in še sosednji mirovno operacijo.
} 
(Vandergriff, 2006, str. 43), ki jo lahko starešinskemu zboru privzgojimo tako, da ga $\mathrm{v}$ procesu izobraževanja čim večkrat soočamo z različnimi nalogami, ki jih mora rešiti, in da vanje sproti vnašamo nove nepričakovane elemente. Inovativnost se doseže tako, da je ljudem dovoljeno poskusiti alternativne načine reševanja in preverjanje zamisli, tudi za ceno neuspeha, in se učiti na podlagi pridobljenih izkušenj. Eksperimentiranje in premišljeno tveganje je treba spoštovati in spodbujati (Vandergriff, 2006, str. 22).

Kritično razmišljanje ne pomeni dvoma v odločitve ali usmeritve nadrejenih, temveč razumevanje skladno s položajem, s katerim je mlad častnik ali podčastnik na terenu soočen. Ta namreč običajno ne dopušča dobesedne interpretacije ukazov, temveč zahteva poglobljeno razumevanje namere nadrejenega. V tem pogledu je upoštevanje poveljevanja z namero (nem. Aufstragtaktik) bistveno. Prav tako je pri izobraževanju starešinskega kadra treba razvijati sposobnost hitrega odločanja na podlagi omejenih ali nepopolnih informacij. Paradigma, da je boljša 80-odstotna rešitev takoj, kot 100-odstotna prepozno, še vedno velja.

Bistvena zahteva za starešine in moštvo $\mathrm{v}$ četrti generaciji vojskovanja je samodisciplina. Samodisciplina pomeni podlago, na kateri se razvijeta prilagodljivost in pobuda. Med profesionalnim izobraževanjem morajo starešine sami ugotoviti, da je potrebna disciplina, če se želijo uspešno spopasti s stresom vadbenih situacij, ki so jim izpostavljeni ${ }^{15}$ (Vandergriff, 2006, str. 88). Nepotrebnih in nesmiselnih pravil se je treba znebiti, vodje pa bi morali dati jasno vedeti, da od moštva pričakujejo visoko raven discipline, ne zaradi kazni, ki bi nedvomno sledile, temveč zaradi želje po dokazovanju (Lind \& Thiele, 2015). Menimo, da sistem izobraževanja in usposabljanja starešinskega kadra v SV ne omogoča oblikovanja vodij, ki bi ustrezali tem zahtevam. ${ }^{16}$ Vprašanje je tudi, če bi bil sposoben uresničiti zgornje zahteve, če bi to nalogo dobil. V SV ni profesionalnih spodbud, ki bi za sistem vojaškega izobraževanja in usposabljanja zagotavljale najboljše kadre. ${ }^{17} \mathrm{Na}$ podlagi sklepov Strateškega pregleda obrambe $2016^{18}$ in osebnih izkušenj menimo, da je rezultat sedanjega vojaškega izobraževanja in usposabljanja v SV zelo nedefiniran vodja.

\footnotetext{
${ }^{15}$ Pri tem je vloga inštruktorjev ključna, saj morajo ves čas paziti na odklone, ki bi pomenili nediscipliniranost, in jih ustrezno sankcionirati. Več primerov navede Vandergriff v svoji knjigi.

${ }^{16}$ Programi usposabljanj starešinskega kadra (podčastnikov in častnikov SV) med cilji poleg drugega navajajo pobudo in prožnost, kar je seveda dobro in skladno s potrebami četrte generacije vojskovanja. Vendar pa je kot vedno težava na izvedbeni ravni, na kateri je veliko odvisno od kakovosti izvajalcev. Poleg tega je težko verjeti, da je pobudo in prilagodljivost mogoče razvijati v okolju, $v$ katerem so vse ure natančno določene in omejene s splošno delovnopravno zakonodajo.

17 Pri tem mislimo na spodbude, ki bi bile privlačne za dobre častnike in podčastnike, ker bi omogočale horizontalno napredovanje in zagotavljale razmere za opravljanje višjih dolžnosti. Vse prave profesije (na primer zdravniki in pravniki) to poznajo. Dokler pa imamo CVS̆ na enem koncu države in sistem, v katerem je mogoče odgovorno poveljniško ali štabno dolžnost opravljati tudi brez opravljene dolžnosti v CVŠ (predavatelj) inštruktor), v sistem vojaškega izobraževanja in usposabljanja ne bomo pritegnili najboljših.

${ }^{18}$ V SPO 2016 je jasno zapisano, da se je po letu 2009 vlaganje v vojaško izobraževanje in usposabljanje zmanjševalo ter da je za izboljšanje razmer $v$ SV nujno izvesti več kratkoročnih ukrepov na tem področju.
} 
Menimo da Center vojaških šol kljub drugačnim deklarativnim normam ne opravlja selekcije mladih podčastnikov in častnikov. ${ }^{19}$ Niti ni v SV enote, ki bi načrtno vzgajala, selekcionirala in razvrščala mlade podčastnike in častnike. Nekdaj je to poizkušal 10. bataljon za mednarodno sodelovanje oziroma 10. motorizirani bataljon, a je sčasoma moral opustiti te selekcijske postopke, zato je izgubil večino posebnega etosa ${ }^{20}$. Da bi lahko ustvarili vodje za četrto generacijo vojskovanja, je nujno kandidate na vseh ravneh izpostaviti visokim standardom, ki bodo od njih zahtevali skrajne psihične in fizične napore. ${ }^{21}$ Še pomembnejši kot visoki psihofizični standardi v sistemu vojaškega izobraževanja in usposabljanja so ustrezni inštruktorski in učiteljski kadri, ki bodo razumeli četrto generacijo vojskovanja in izkazovali značilnosti, ki jih morajo vodje v njej dosegati. V SV je le še ena enota, ki v resnici izpolnjuje zahteve četrte generacije vojskovanja. To so specialne sile SV oziroma Enota za specialno delovanje (v nadaljevanju ESD).

To je enota, ki zaradi narave svojega poslanstva in visokih vstopnih standardov zares goji organizacijsko kulturo lahke pehote, potrebne v četrti generaciji vojskovanja. Njihovo bistveno načelo je osredotočenost na rezultat, med drugim gojijo in cenijo pobudo, prilagodljivost in samodisciplino. Zaradi narave svojega dela delujejo zelo decentralizirano. Nestvarno bi bilo pričakovati ali celo zahtevati, da gredo vsi pripadniki SV skozi selekcijske postopke te enote. Kot je bilo že ugotovljeno, lahka pehota ni nikakršen ekvivalent specialnim silam. Specialne sile imajo svojo vlogo in nalogo v četrti generaciji vojskovanja, preostali elementi oboroženih sil pa svojo. Nujno je le, da se organizacijska kultura osredotočenosti na rezultat, pobude, prilagodljivosti in samodiscipline razširi na celotne oborožene sile. To je mogoče le prek starešinskega kadra ter sistema izobraževanja in usposabljanja. ESD je premajhna in predragocena zmogljivost, da bi jo uporabljali kot nadomestek za Center vojaških šol ( $v$ nadaljevanju CVŠ), ki v resnici predstavlja sistem izobraževanja in usposabljanja starešinskega kadra SV. Kar je nujno, je vzpostaviti formalizirane povezave med ESD in CVŠ, da bi se organizacijska kultura ESD razširila na preostanek SV. Da bi se to sploh lahko zgodilo, je predvsem treba po eni strani resno začeti graditi polne zmogljivosti ESD in po drugi za četrto generacijo vojskovanja uvesti ustrezne selekcijske standarde na vseh ravneh izobraževanja in usposabljanja v CVŠ. Sočasno je treba opredeliti pogoje, ki jih mora izpolnjevati učiteljski in inštruktorski kader CVŠ, da bo na vseh področjih ustrezal zahtevam

\footnotetext{
19 Selekcije šole za častnike in drugih tečajev SV, ki jih opravi $99 \%$ prijavljenih, pač ne moremo šteti kot resne. Tudi tisti, ki se ne odločijo za to delo, običajno ne odpadejo zaradi visokih standardov, temveč zaradi drugih razlogov. O tem, kakšni so pogoji za vpis na štabne in višje štabne tečaje, krožijo »urbane« legende. Če pogledamo starostno strukturo tečajnikov na višjem štabnem tečaju leta 2016, se lahko upravičeno vprašamo, koliko teh ljudi je tik pred upokojitvijo.

${ }^{20}$ Rdeča baretka je nekdaj dokazovala, da je pripadnik uspešno opravil tako imenovano »fazo«, pri čemer med častniki, podčastniki in vojaki ni bilo razlikovanja. Kakršni koli so že bili ti selekcijski standardi in kakor koli so se že uresničevali, je neizpodbitno, da je v enoti in očeh pripadnikov tudi na ta račun vladal poseben etos.

${ }^{21}$ Seveda bi bilo narobe zahtevati nemogoče. Vstopni fizični standardi morajo zagotoviti, da jih bodo opravili samo tisti, ki bodo lahko prenašali bremena četrte generacije vojskovanja. To še ne pomeni, da morajo biti že na vstopni točki sposobni vsega. V tem pogledu je treba znati oceniti potencial in vztrajnost posameznika. Vstopni standardi tudi niso vezani le na fizične sposobnosti, temveč morajo še prav posebej preveriti psihične in intelektualne meje posameznika.
} 
četrte generacije vojskovanja, ter uvesti primerne spodbude za njegovo delo. ${ }^{22}$ Šele nato bi se lahko opredelili učiteljske in inštruktorske dolžnosti, ki jih za določeno obdobje popolnjujejo pripadniki $\mathrm{ESD}^{23}$, in tečaji oziroma programi, ki jih na vseh ravneh šolanja častniškega kadra izvedejo ti pripadniki. Ko bi potrdili prve učinke takšne povezave, bi lahko sistem po vzoru 173ABCT razširili še na povezavo med enoto (polkom) lahke pehote in ESD. ${ }^{24}$

Ob tem seveda ne smemo domnevati, da so samo pripadniki ESD lahko dobri učitelji in inštruktorji v CVŠ. V SV so častniki in podčastniki, ki instinktivno razumejo četrto generacijo vojskovanja in vedo, kakšno znanje je nujno za uspešno delovanje v njej. ESD tudi nima dovolj znanja za vse ravni in vse oblike specialističnega šolanja. Večina učiteljskega in inštruktorskega kadra na CVŠ bo še vedno prihajala od drugod, zato je treba zanj postaviti ustrezne selekcijske standarde pri razumevanju koncepta četrte generacije vojskovanja. Da bi CVŠ in predvsem starešinski kader, ki je tam na izobraževanju in usposabljanju, sprejela ustrezno organizacijsko kulturo in jo vzdrževala, je treba zagotoviti formalizirano, stalno in dovolj veliko prisotnost pripadnikov ESD v CVŠ. Tudi to ne bo imelo ustreznega učinka, če ne bo ustreznih nagrad za opravljanje dolžnosti in kazni, če dolžnosti ne bodo opravljene. ${ }^{25}$

Treba je poskrbeti, da vstop v častniški in podčastniški zbor, torej v voditeljski del vojske, postane težji. Geslo bi moralo biti bolje brez vodje kot s slabim (Vandergriff, 2006, str. 74). Spremembe v organizacijski kulturi so predvsem spremembe v kulturi vojaškega izobraževanja in usposabljanja. Moramo se zavedati, da so predlagane spremembe projekt, ki bi moral trajati vsaj deset let, da bi lahko bil v celoti uspešen.

\subsection{Usposabljanje}

Usposabljanje lahke pehote je zelo zahtevno. Lahka pehota se usposablja v razmerah, ki bi jih najbolje opisali z besedami, kot sta beda in pomanjkanje (McMichael, 1987). Poudarek je na fizični in psihični pripravljenosti na spoprijemanje z najtežjimi nalogami ob pomanjkanju spanca in hrane, pri čemer mora biti pomanjkanje ustrezno dozirano,

${ }_{22} \check{C}$ e na CVŠ ne poskrbimo za kader, primeren za četrto generacijo vojskovanja, je vse drugo zaman. Ključ do uspeha ni toliko v ustreznih selekcijskih standardih za tečajnike kot v ustrezni izbiri učiteljskega osebja na CVS̆. $O$ tem je podrobneje pisal Vandergriff $v$ Breaking the modl.

${ }^{23}$ Te dolžnosti morajo biti strateško izbrane, da bi se organizacijska kultura ESD lahko širila med starešinski kader SV.

${ }^{24}$ V $173 A B C T$ so formalizirana delovna mesta, ki jih za 3-4 leta popolnjujejo pripadniki ameriških specialnih sil. Po opravljeni rotaciji v 173ABCT se ti pripadniki USSOF vrnejo nazaj v specialne sile. Ameriška vojska pozna tudi sistem t. i. Ranger School, ki v nasprotju s splošnim mnenjem ni namenjen usposabljanju enot rangerjev, temveč veliko bolj temu, da se najnižji vodje v ameriški vojski indoktrinirajo z organizacijsko kulturo, ki velja $v$ teh enotah. Namen je, da bi se ta organizacijska kultura prenesla na vso ameriško vojsko, vendar po našem mnenju v tem niso tako uspešni, kot bi lahko bili. Vzroki so v preveliki organizaciji, v kateri se težko ustvari kritična masa častnikov, ki so končali to šolo, s katero bi lahko dosegli pravo spremembo v kulturi organizacije. Poleg tega šola ni del TRADOC in tako niti nima neposredne povezave s sistemom izobraževanja in usposabljanja, ki v resnici oblikuje organizacijsko kulturo starešinskega kadra ameriške vojske. Menimo, da je bistvena razlika med tem, kar predlagamo, in tem, kar lahko vidimo v nekaterih enotah ameriške vojske, ravno v neposredni povezavi med ESD in CVS̆.

${ }^{25}$ Kot je npr. opredelitev zahteve po tem, da vsi bodoči poveljniki polkov (ali enake ravni $v$ SV) na ravni od poveljnika voda do čete prej 3-4 leta poučujejo na CVŠ. 
da se lahko razvije želena odpornost. Druga pomembna prvina usposabljanja lahke pehote je razvijanje pobude, še posebno pri podčastnikih in mlajših častnikih (Lind in Thiele, 2015). Pobuda in prilagodljivost se razvijeta tako, da se v usposabljanje vnašajo nepričakovane zahteve in naloge, ki zahtevajo takojšnji odziv. Patruljiranje in infiltracija sta dve taktični prvini, ki razvijata pobudo. Razvijanje pobude je podobno kot fizično pripravljenost treba vključiti v programe usposabljanja povsod, kjer je mogoče. Pomanjkanje, fizična vzdržljivost in pobuda so tri prvine usposabljanja, ki neposredno prispevajo k razvoju poglavitnih značilnosti lahke pehote.

Urnik usposabljanja mora omogočati tako imenovano usposabljanje brez določenega konca. Usposabljanje se ne konča ob določeni uri ali dnevu, temveč ko je naloga izpolnjena ali standard dosežen. Fizične zahteve usposabljanja morajo biti ves čas na meji mogočega ${ }^{26}$, poudarek pa na vzdržljivostii ${ }^{27}$. Teža opreme ${ }^{28}$ posameznika med usposabljanjem ne sme presegati $22 \mathrm{~kg}$ oziroma 30 odstotkov njegove gole teže. ${ }^{29}$ To je danes praktično nedosegljivo, saj to, kar velja za standardno opremo vojaka, krepko presega predpisano težo. Tudi izkušnje iz sodobnih spopadov kažejo na to, da so vojaki Natovih članic preobremenjeni z opremo, in sicer tako zelo, da to že bistveno vpliva na njihovo učinkovitost. Na tem področju je nujen oster prelom $\mathrm{z}$ željo po absolutni zaščiti vojaka. Posledica te je namreč preobremenjen, neokreten in slabo gibljiv posameznik, ki je fizično izčrpan, še preden vstopi v boj.

Med usposabljanjem je nujna tako imenovana lovska miselnost (nem. Jaegermentalitet). Orientacija na terenu je izjemno pomembna veščina, tako v gozdu kot v mestu, pri čemer jo je treba pri vojakih razvijati brez sodobnih tehnoloških pripomočkov. S tem je povezana tudi veščina nočnega delovanja, pri čemer odsotnost naprav za nočno opazovanje ne more biti izgovor. Lahka pehota je vedno delovala večinoma ponoči, tudi v časih, ko še niso poznali nočnih opazovalnih naprav. Veščino gibanja in delovanja je treba razvijati ob omejeni vidljivosti in tehnologijo vnašati v usposabljanje le, ko je to nujno (Lind \& Thiele, 2015). S pretiranim zanašanjem na nočne opazovalne naprave tvegamo, da bomo ponoči delovali po enakih načelih kot podnevi, kar utegne imeti tragične posledice, ko bomo soočeni s sovražnikom, ki obvladuje nočno delovanje brez uporabe tehnologije.

Za pripadnike lahke pehote ni nujno le poznavanje, temveč tudi obvladovanje vse organske oborožitve enote (oddelek, vod) in obvladovanje osebne oborožitve sovražnika (Lind \& Thiele, 2015).

\footnotetext{
${ }^{26}$ To ne pomeni, da so od začetka do konca fizične obremenitve maksimalno mogoče, pač pa, da so pripadniki oz. enote ves čas obremenjeni z maksimumom njihove trenutne sposobnosti. Usposobljen in izkušen starešinski kader je $v$ tem pogledu nujen.

${ }^{27}$ Trenutno vsakoletno testiranje pripadnikov SV (t. i. PGS oz. Natov test) ne preverja vzdržljivosti, zato ga je treba nadomestiti s testi, ki jo bodo preverjali.

${ }^{28}$ To je teža vsega, kar ima posameznik oblečeno, obešeno in oprtano na sebi, vključujoč spodnje perilo, nogavice, obutev in uniformo, vse do ročne bombe, čelade in neprebojnega jopiča.

${ }^{29}$ Zgodovinske študije so pokazale, da vojaka lahko obremenimo s precejšnjo težo, pa ne bo bistveno izgubil svoje okretnosti (Knapik, 1989). Zgodovinske ugotovitve povzema tudi FM 21-18 (U.S. Army) Foot Marches.
} 
Zagotoviti je treba tudi negotovost logistične zagotovitve usposabljanja. S tem simuliramo okoliščine bojnega delovanja in askezo $\mathrm{v}$ delovanju enote (Lind \& Thiele, 2015). SV se je z razvojem približala miselnosti $\mathrm{FOB}^{30}$, ki je pogubna za delovanje v četrti generaciji vojskovanja.

Večina zahtev, povezanih z usposabljanjem v lahki pehoti, zahteva drugačno pravnoformalno ureditev okolja za usposabljanje SV. Trenutne zakonske omejitve, pa tudi omejitve v podzakonskih aktih, onemogočajo usposabljanje skladno z zgornjimi zahtevami. Te posebne pogoje usposabljanja bi moral prepoznati ustrezen področni zakon in jih nato urediti na način, ki bi omogočal stvarno usposabljanje, hkrati pa bi pri uživanju vseh pravic delavca $\mathrm{v}$ javni upravi zagotovil ustrezen način izravnave zaradi neenakopravnosti vojakov z drugimi javnimi uslužbenci.

\subsection{Organizacija in struktura}

Sile za bojevanje so lahko »lahke« v svoji organizacijski kulturi, tudi če imajo razmeroma težko (oklepno) organizacijsko strukturo. Nemške gorske divizije med drugo svetovno vojno so delovale po načelih lahke pehote, a so bile večje in težje kot standardne pehotne divizije. Organizacijska kultura lahke pehote ni odvisna od njene strukture. Enote so lahko glede na okolje in okoliščine bojevanja notranje zelo različno strukturirane in organizirane. Brigadne in bataljonske operacije lahke pehote so sicer redkejše. Tudi ko je bila zgodovinsko gledano lahka pehota organizirana v brigade in celo divizije, so bile operacije teh enot precej decentralizirane. Splošno gledano je boj v lahki pehoti stvar čete, vodov in oddelkov (McMichael, 1987).

V organizacijski strukturi SV so bile zadnje večje spremembe opravljene s preoblikovanjem leta 2012, pri čemer se pogosto pojavljajo mnenja, da je bilo to preoblikovanje popolnoma zgrešeno (npr. Šavc v Pišlar, 2016, str. 12) ${ }^{31}$. Neustreznost nekaterih sprememb po našem mnenju ni težava nove organizacijske strukture SV, temveč njene organizacijske kulture. Vse preveč se je kot razlog za preoblikovanje poudarjalo pomanjkanje finančnih sredstev, tudi če je to očitno in boleče. Menimo, da SV z več denarja, usmerjenega v nove nakupe, svojih bistvenih pomanjkljivosti ne bi odpravila, le lažje bi jih prikrila pred seboj in javnostjo. Bistvene pomanjkljivosti so namreč $\mathrm{v}$ sistemu izobraževanja in usposabljanja (predvsem častnikov) in $\mathrm{v}$ neprimerni organizacijski kulturi ${ }^{32}$. Te pa je z investicijami v opremo nemogoče popraviti. V povezavi s preoblikovanjem leta 2012 se navajajo štiri velike napake, pri tem pa se pozablja, da preoblikovanje ni bilo izvedeno v vseh načrtovanih fazah.

\footnotetext{
${ }^{30}$ Gre za delovanje, pri katerem enote v operaciji (pa tudi med usposabljanjem) bivajo v velikih bazah (angl. forward operating base), $v$ katerih imajo na voljo vse ugodnosti civilnega življenja in varnost, za katero niso odgovorni sami. To so nekakšni otoki normalnosti na območjih, na katerih normalnost ni naravno stanje.

${ }^{31}$ G. Šavc je, kot je avtorju znano, do zdaj edini javno spregovoril o napakah pri preoblikovanju leta 2012. S tem je odprl možnost za odkrito strokovno javno razpravo, ki prej pač ni bila mogoča.

${ }^{32}$ O ugotovitvah raziskave dr. M. Jakič in o tem, kakšna je organizacijska kultura SV, smo razpravljali v prejšnjem prispevku (Potočnik, 2017, str. 62-63). Če povežemo ugotovitve te raziskave z organizacijsko kulturo za četrto generacijo vojskovanja, vidimo, da je organizacijska kultura SV zanjo povsem neprimerna.
} 
Prva napaka naj bi bila uvedba enakovrednih brigad dvojčic in vzdrževanje dveh poveljniških struktur na ravni brigade. Res je, da je stalne sestave SV primerjalno gledano z brigadami Nata številčno le za slabo brigado, vendar pozabljamo, da doktrinarno brigada SV ni namenjena delovanju v Natu, temveč le na domačem ozemlju. Najmanj, kar to pomeni, je precej manjši logistični podpis brigade SV. ${ }^{33}$ Glavni pozitivni učinek preoblikovanja leta 2012 pa je sposobnost brigade za izvajanje združenega bojevanja rodov, ki je zdaj neprimerno večja, kar dokazujejo usposabljanja in vaje SV po preoblikovanju, na katerih se vsi rodovi usposabljajo skupaj (pehota z inženirci, JRKBO, artilerija). Kar je zdaj pravilo, je bilo pred preoblikovanjem izjema in je neposredna posledica spremenjene organizacijske strukture brigad. Očitek, da se zdaj vzdržujeta dve poveljniški strukturi na brigadni ravni, spregleduje, da je imela SV že pred preoblikovanjem dve brigadni poveljstvi in poveljstvo brigade vojnega letalstva.

Naslednja napaka naj bi bila ukinitev poveljstva sil kot poveljstva na operativni ravni. Menimo, da $\mathrm{v}$ resnici to ni bilo načrtovano in da se $\mathrm{z}$ vzpostavitvijo Združenega operativnega centra (ZOC) to tudi ni zgodilo. V SOPR 2013-2018 je ta center jasno opredeljen kot poveljstvo operativne ravni, ki bo »pristojno za poveljevanje in kontrolo pripravljenim silam doma in silam, ki delujejo v tujini, ter za kratkoročno načrtovanje in samostojno vodenje aktivnosti« (SOPR, 2013, str. 18). V veljavnem SOPR 2016-2018 je zapisano, da bo SV »organizirana tako, da bo zagotavljala delovanje na strateški, operativni in taktični ravni« (SOPR, 2016, str. 35). Z nadaljevanjem preoblikovanja leta 2017 bi bili lahko priče ponovni uvedbi poveljstva operativne ravni, pri čemer pa GŠSV kot poveljstvo strateške ravni žal ni integriran v MO, kar je bil eden ciljev preoblikovanja leta 2012 in kar je zapisano tudi v veljavni ReSDPRO 2025 (str. 55).

Razpustitev rodovskih bataljonov, predvsem bataljona JRKBO, naj bi bila prav tako napaka. Menimo, da o tem v SV prevladuje največja mogoča demagogija in čeprav se strinjamo s tem, da je bila uporaba uravnilovke napaka, nismo povsem prepričani, da je bila napaka v celoti. Rodovski bataljoni so danes predstavljeni kot začetek in konec strokovnosti. Menimo, da se stroka ne razvija v enotah, razvija se s profesionalnim sistemom vojaškega izobraževanja in delujočimi štabnimi organi na generalštabu, ki skrbijo za razvoj rodov. V enotah pa se stroka izvaja. In če vzamemo doktrinarno predpostavko brigadne bojne skupine kot najvišje oblike bojnega delovanja v SV, se za marsikateri rod zastavlja vprašanje smiselnosti organizacije na bataljonski ravni. Predvsem so to bataljon JRKBO, vojaška policija, zračna obramba in zveze. Vse te enote na bataljonski ravni namreč bistveno presegajo doktrinarne potrebe SV. ${ }^{34}$ Če bi razmišljali znotraj koncepta lahke pehote, sta vprašljiva tudi artilerija

\footnotetext{
${ }^{33}$ Logistični bataljoni na ravni brigade v ZDA predstavljajo $28 \%$ (HBCT), $23 \%$ (IBCT) in $17 \%$ (SBCT) moštva celotne brigade. Na ravni manevrskih bataljonov poveljniško-logistični elementi predstavljajo približno $30 \%$ moštva bataljonov (FKSM, 2010). Seveda to ne pomeni, da so brigade SV lahko toliko manjše. Še vedno tudi za delovanje v RS potrebujejo logistično zagotovitev, a ta je lahko neprimerno manjša.

${ }^{34}$ Ob tem se zavedamo, da je res vprašanje, kako smiselna je bila ukinitev bataljona JRKBO. Ne, ker bi ga SV potrebovala, ampak zato, ker je bila zmogljivost za zavezništvo zgrajena in je bilo vanjo vloženo veliko sredstev.
} 
in inženirstvo. Seveda se vedno najdejo razlogi, ki opravičujejo obstoj teh enot na bataljonski ravni, na primer z zavezami do Nata ali s potrebami zaščite, reševanja in drugih elementov nacionalnovarnostnega sistema. Tem argumentom seveda ni mogoče oporekati, le da nimajo nobene zveze z vojaško stroko. Če je z vidika drugih elementov nacionalnovarnostnega sistema (zunaj SV) obstoj teh enot na bataljonski ravni nujen, je treba to tako tudi zapisati in prek teh elementov tudi zagotoviti vire za njihov obstoj. Po našem vedenju v SV tudi nikoli ni bila opravljena resna strokovna razprava z zavezujočimi sklepi, ki bi obravnavala problematiko rodov. ${ }^{35}$ Vsekakor ni bila ponujena na vpogled širši strokovni javnosti.

Centralizacija oklepnih vozil v tako imenovani avtopark je zadnji veliki očitek preoblikovanju leta 2012, ki se pojavlja. Tu se strinjamo z oceno nekaterih, da se zamisel ne zdi skladna z našo miselnostjo, res je tudi, da jo opuščajo tudi druge vojske. Toda to ne opravičuje odklonov na izvedbeni ravni (namernih ali nenamernih), ki se ne bi smeli zgoditi in so v resnici onemogočile uresničljivost zamisli (avtopark bi moral imeti mehanike, ne pa voznikov in namerilcev). Poleg tega se je SV tu srečala tudi s posledicami dolgoletne nenapisane kadrovske politike, po kateri je vse, kar ni bilo dovolj dobro ali zanesljivo za bojne enote, končalo v logistiki ali vojaškem šolstvu - seveda s svetlimi izjemami. Drugo je, da je za delovanje avtoparka potreben kulturni preskok, za katerega se zdi, da se ga SV niti ne zaveda.

Če kaj, je bila napaka, da je bil pristop k ukinjanju rodovskih enot (tudi pehote) egalitaren (če enega, potem vse), brez resne analize potreb in izvedljivosti. Predvsem pa je bilo preoblikovanje prehitro, čeprav so zanj nedvomno obstajali razlogi. Zdi se, da je bilo podobno tudi s pripravo strateškega pregleda obrambe za leto 2016. To sicer ne pomeni nujno, da je izdelek slab, vendar hitenje pri njegovi pripravi vzbuja najmanj dvom v kakovost izvedbe. Kot da se nismo ničesar naučili. Če je zamisel nastala v glavah vodij, to še ne pomeni, da je uresničljiva. Da to postane, jo je treba ustrezno predstaviti podrejenim, ki jo morajo sprejeti za svojo, sicer se srečamo z nepotrebnim odporom, nerazumevanjem in celo nagajanjem.

Nekaterim domnevnim napakam, nastalim v preoblikovanju 2012, smo se posvetili, ker menimo, da pri razmišljanju o strukturi in organizaciji SV znotraj četrte generacije vojskovanja ne moremo mimo tega, da bodo potrebne velike kulturne, organizacijske in strukturne spremembe, nepripravljenost nanje pa je posledica odpora do preoblikovanja leta 2012.

\subsection{Popolnjevanje}

Kot smo že ugotovili, sedanji sistem popolnjevanja ne zagotavlja dovolj moštva niti za trenutno dovoljeni obseg SV, kaj šele za morebitno rast vojaške strateške rezerve. $\mathrm{S}$ tem se bo treba sprijazniti in čim prej ugotoviti, da kozmetični popravki zakona o obrambi in drugih podzakonskih aktov, s katerimi naj bi izboljšali status vojaka, ne

${ }_{35}$ Dopuščamo sicer možnost, da se je to zgodilo in so rezultati teh razprav nekje v arhivu. 
bodo zadostovali. SV mora spremeniti sistem popolnjevanja, da zagotovi ustrezen obseg za delovanje v četrti generaciji vojskovanja.

Stalna sestava bi morala zadoščati za oblikovanje vojaško relevantnih zmogljivosti, za katere smo se zavezali zavezništvu. Poleg tega je treba računati tudi z institucionalnim deležem, ki je nujen in bo zadostoval tudi za potrebe rezervne sestave. Tu se je treba zavedati, da želena piramidna struktura $\mathrm{v}$ odnosu častniki, podčastniki in vojaki v stalni sestavi ne bo nikoli mogoča. Pozabljamo namreč, da vojska za svoje delovanje, ne glede na obseg oziroma število bojnih enot taktične ravni, potrebuje nekatere podsisteme za svoj obstoj in delovanje. ${ }^{36}$ To so zelo pomembni podsistemi, kot so vojaško izobraževanje in usposabljanje, znanstvenoraziskovalne dejavnosti, poveljevanje in kontrola idr., brez katerih vojske v pravem pomenu besede ne more biti, ki zahtevajo ustrezno število strokovno primernih častnikov in podčastnikov. ${ }^{37}$ Ob tem se pogosto pozablja, da tudi Teritorialna obramba RS ni bila samostojna organizacijska enota, temveč se je v izobraževalnem, znanstvenoraziskovalnem, razvojno-tehničnem in mnogih drugih pogledih v celoti opirala na sisteme JLA.

Lahka pehota tudi ne izključuje naborništva. Za zavezništvo manj relevantne zmogljivosti bi lahko popolnjevali tudi z naborniki. Njihovo usposabljanje bi moralo potekati najmanj do vodne ravni. Hkrati bi pomenili vir moštva za popolnjevanje potreb po vodjih tako v stalni kot rezervni sestavi. Ustreznemu moštvu bi se po odsluženem vojaškem roku ponudila tudi možnost nadaljnje pogodbene službe $\mathrm{v}$ stalni sestavi, ki bi trajala od enega do treh let (ena do dve rotaciji v MOM). Ob tem predlogu bi bila nujna analiza rezultatov naborništva pred letom 2003. Vsekakor pa menimo, da je nujnih več kot štiri mesece služenja vojaškega roka za usposobitev dostojne lahke pehote na vodni ravni. ${ }^{38}$ Večina nabornikov in tudi pogodbenih pripadnikov stalne sestave bi se po končani službi razporedila v rezervno sestavo $\mathrm{v}$ potrebnem obsegu in trajanju. Neizpolnjevanje minimalnih meril služenja v rezervi bi moralo pomeniti odpust iz nje, čemur bi moral slediti tudi ukrep, ki bi posameznike odvračal od izogibanja temu služenju. Ključne bi bile tudi delne mobilizacijske vaje, s katerimi bi preverjali odzivnost mobilizacijskega sistema SV. Po koncu službe v rezervi bi posamezniki ostali na seznamih vojaške strateške rezerve, a brez obveznosti v miru.

\footnotetext{
${ }^{36}$ To v praksi pomeni, da v bistvu potrebujemo enako velike sisteme PINK, ViU, MSSVT itn. ne glede na to, ali imamo dva polka pehote ali jih je pet ali petnajst. Razlike so $v$ rezultatih teh podsistemov, ne toliko $v$ njihovi velikosti.

${ }_{37}$ Seveda je mogoče nekatere podsisteme nasloniti tudi na civilne, toda ne vseh in ne v pretežnem delu, ker sicer vojska izgubi svoj profesionalni potencial.

${ }^{38}$ Lind in Thiele ocenjujeta, da je za transformacijo frontne pehote v lahko pehoto potrebnih 20 tednov (5 mesecev), in sicer ob predpostavki, da so že pridobili to, čemur bi v SV dejali osnovno vojaško evidenčno dolžnost (VED), kar za vojaka pehote v SV traja približno pet mesecev. Ti časi veljajo za transformacijo frontne pehote v lahko pehoto. Če celoten koncept že v izhodišču zastavimo drugače, je skupni čas mogoče precej skrajšati.
} 
Sklep »Od stotih mož jih deset sploh ne bi smelo biti tam, osemdeset jih samo predstavlja tarčo, devet je pravih borcev in lahko smo veseli, da jih imamo, saj je zaradi njih bitka sploh možna. Ampak eden, eden je bojevnik, in on bo vse druge pripeljal nazaj. $\ll^{39}$ Heraklit (500 pr. n. š.)

Za delovanje in uspešno spopadanje s sovražnikom v četrti generaciji vojskovanja potrebuje SV drugačno organizacijsko kulturo. Kot piše Poole, se zmogljivosti lahke pehote oziroma gverilske vojske in visoko tehnološke zmogljivosti manevrskega vojskovanja ne izključujejo (Poole, 2001, str. 11). SV sama zase ne more biti uspešna v konfliktih četrte generacije, sploh pa ne v konfliktih visoke intenzivnosti, ki so njihov sestavni del. Hkrati se jim ne more izogniti. Samo če bomo aktivno sodelovali v zavezniških povezavah lahko pričakujemo, da bomo lahko soodločali in odločali o svoji usodi. To pa ne more in ne sme pomeniti, da vse svoje sile usmerjamo $\mathrm{v}$ zavezništvo. V zavezništvo moramo prispevati vojaško relevantne zmogljivosti in izpolnjevati zaveze, ki jih sprejemamo. Pri tem zaveznikov ne zanima, koliko sredstev namenjamo za obrambo, temveč le, kaj prispevamo k skupni varnosti. Ob tem bomo morali za varnost na svojem ozemlju poskrbeti predvsem sami. In za to je najprimernejši koncept lahke pehote, ki zagotavlja množičnost in prilagodljivost, da jo je mogoče uporabiti v celotnem spektru nalog, od pomoči pri zaščiti in reševanju, $v$ mirovnih operacijah ter operacijah v podporo stabilnosti in obnovi, do čisto vojaških operacij. Četudi organizacijska struktura lahke pehote ni najprimernejša za operacije visoke intenzivnosti, to še ne pomeni, da to velja tudi za njeno organizacijsko kulturo.

Vse našteto se ne bo zgodilo samo po sebi, ne z zapisom želja na kos papirja ne $\mathrm{z}$ razpravami oziroma posveti $\mathrm{v}$ parlamentu ali s strokovnimi debatami. Kulturne spremembe se začnejo z zaželenim vedenjem in voditelji, ki ga podpirajo, za kar morajo biti zagotovljene tudi ustrezne spodbude in kazni.

Priprava nujnih sprememb in razmislek o njih ne zahtevata posebnih virov. Zahtevata pa intenzivno komunikacijo SV s politiko in družbo, ki temelji na strokovnih podlagah. Nadaljnja uveljavitev nujnih sprememb in vzpostavitev obrambnih zmogljivosti, ki bodo ustrezale četrti generaciji vojskovanja, bosta zahtevali precej več od trenutnih 0,9 odstotka BDP. Zaradi načrtnega zapostavljanja in zlorabljanja obrambnih zmogljivosti v zadnjih 20 letih bo to žal precej več, kot so trenutne politične obljube. Dolgoročno bi se ta znesek moral stabilizirati okrog 1,5 odstotka BDP, kar je še vedno manj, kot bi morali namenjati za varnost, če bi se odločili za samostojno obrambno držo $(2,5-2,7 \text { odstotka })^{40}$.

\footnotetext{
39 „Out of every one hundred men, ten shouldn't even be there, eighty are just targets, nine are the real fighters, and we are lucky to have them, for they make the battle. Ah, but the one, one is a warrior, and he will bring the others back."

${ }^{40}$ Ocene so avtorjeve in temeljijo na metodologiji, ki je bila podrobneje opisana v prejšnjem prispevku (Potočnik, 2017, str. 54).
} 


\section{Literatura}

1. Državni zbor RS, 2011. Resolucija o splošnem dolgoročnem programu razvoja in opremljanja Slovenske vojske do leta 2025 (ReSDPRO 2025). Uradni list RS, št. 99/2010, $z$ dne 7. 12. 2010.

2. FKSM 71-8, 2010. Armor/Cavalry reference data; Brigade combat teams. US Army Armor Center, Fort Knox, KY.

3. FM 21-18, 1990. Foot Marches. HQ Department of the Army, Washington, DC.

4. Furlan, B. (in drugi), 2006. Vojaška doktrina. Defensor, Ljubljana.

5. Grizold A., 1999. Obrambni sistem Republike Slovenije. MNZ, Visoka policijskovarnostna šola, Ljubljana.

6. KnapikJ., 1989. Loads carried by soldiers: Historical, Psysiological, Biomechanical and Medical Aspects. US Army Research Institute of Enviromental Medicine, Natick, Massachusetts.

7. Lind, W.S., in Thiele, G.A., 2015. 4TH Generation Warfare Handbook. Castilia House. Kouvola, Finland (Kindle book).

8. McMichael, S.R., 1987. A Historical Perspective on Light Infantry. Research survey/ Combat Studies Institute; no. 6. U.S.A. CGSC, Fort Leavenworth, KS. http://usacac.army. mil/cac2/cgsc/carl/download/csipubs/HistoricalPerspectiveonLightInfantry.pdf).

9. NATO, 2016. Bi-Sc Agreed Capability Codes and Capability Statements. Belgium: Supreme Allied Commander, Europe.

10. Pišlar, M., 2016. Denarja za obrambne izdatke je premalo, če želimo SV obdržati. pogovor z generalnim direktorjem Direktorata za obrambno politiko Primožem Šavcem. Intervju v reviji SV št. 4, april 2016, MO, Ljubljana.

11. Poole, H. J., 2001. Phantom soldier - the enemy's answer to U.S. firepower. Posterity Press, Emerald Isle, NC.

12. Potočnik, V., 2017. Četrta generacija vojskovanja 2. del: celovita prenova nacionalnovarnostnega sistema. SVI, MO, Ljubljana.

13. Selig, R.A. \& Skaggs, C.D., 1991. Treatise on Partisan Warfare (Abhandlung uber den kleinen Krieg); Johan Ewald. Greenwod Press, Westport, CT.

14. Vandergriff, D.E., 2006. Rasing the Bar; Creating and Nurturing Adaptability to Deal with the Changing Face of War. Center for Defence Information, Washington, D.C.

15. Vlada RS, 2004. Zakon o obrambi (uradno prečiščeno besedilo). Ljubljana: Uradni list RS, št. 103/04 in št. 95/15.

16. Vlada RS, 2013. Srednjeročni obrambni program Republike Slovenije 2013-2018. Ljubljana: št. 80300-1/2013/3, z dne 1. 2. 2013.

17. Vlada RS, 2016. Srednjeročni obrambni program Republike Slovenije 2016-2020. Ljubljana: št. 80300-2/2016/3, z dne 17. 2. 2016.

18. Vlada RS, 2016. Sklepi strateškega pregleda obrambe 2016. Ljubljana: št. 80400 1/2016/6, z dne 22. 12. 2016. 


\title{
TEMELJNO ŠOLANJE ČASTNIKOV V DRŽAVAH EVROPSKE UNIJE - ISKANJE ODGOVOROV NA SODOBNE ZAHTEVE
}

\author{
BASIC OFFICER TRAINING IN EUROPEAN \\ UNION COUNTRIES - SEEKING ANSWERS \\ TO CONTEMPORARY REQUIREMENTS
}

Povzetek V razpravah glede prihodnjega šolanja častnikov v Sloveniji je pomembno tudi preučevanje modelov v tujini in sodobnih problemov na tem področju. V prispevku so na kratko prikazani izzivi na področju temeljnega šolanja častnikov, predvsem z vidika razmerja med usposabljanjem za konkretne naloge in širše usmerjenim izobraževanjem. Kakovost izobraževanja je pomembna ne le za vojaško učinkovitost, temveč tudi za odnos vojske s civilnimi strukturami v državi in z mednarodnim okoljem. Prikazane so temeljne poteze šolanja častnikov v državah EU. Proces šolanja sestavljata dve medsebojno povezani komponenti: univerzitetno izobraževanje in poklicno usposabljanje. Sicer pa šolanje častnikov ostaja le pristojnost držav in v državah EU najdemo zelo različne modele. Temeljno šolanje častnikov v Sloveniji se glede glavnih sestavin ne razlikuje bistveno od prakse v večini držav EU, vendar bo $\mathrm{v}$ prihodnje treba odgovoriti na nekatera vprašanja, predvsem glede razvoja univerzitetnega izobraževanja. Prihodnji razvoj šolanja častnikov bo moral slediti praksi evropskih držav predvsem na vsebinskem področju. Način organiziranja pa je smiselno prilagoditi lastnim potrebam in zmožnostim.

Ključne Vojaško izobraževanje in usposabljanje, vojaška profesija, šolanje častnikov, besede Evropska unija, vojska in družba.

Abstract In the context of discussion about future officer education in Slovenia, it is important to study the current educational models in foreign countries and the contemporary problems in this area. The article briefly depicts challenges of basic officer education mainly from the viewpoint of relations between specific-purpose training and more broadly oriented education. The quality of education is important not only for military efficiency but also for military's relations with national civil structures and international environment. The article illustrates basic features of officer education in EU member states. The educational process consists of two interlinked parts: academic 
education and vocational training. Officer education is the sole responsibility of EU member states, and they practise very different models. Concerning its essential parts, officer education in Slovenia does not differ significantly from that of most EU members. However, it will be necessary to address some open questions, primarily those concerning the academic part of education. The future development of officer education should follow the patterns emerging in European states, first of all regarding educational content. However, it makes sense to adapt its organisational characteristics to our own needs and abilities.

Key words Military education and training, military profession, European Union, officer education, military and society.

Uvod V Sloveniji smo v zadnjih dveh desetletjih vzpostavili lasten model šolanja častnikov, hkrati pa potekajo tudi razprave o ustreznosti tega modela in morebitnih spremembah. ${ }^{1} \mathrm{~V}$ dokumentih najdemo usmeritve, da naj bi šolanje postalo čim bolj primerljivo z modeli šolanja v tujini. Tako v Vojaški doktrini (2006, str. 35) ugotavljamo, da je sistem izobraževanja in usposabljanja »primerljiv s sistemi vojska v zavezništvu«. V veljavnem SOPR ${ }^{2}$ je zapisano, da bodo postopno »upoštevani merila in standardi, ki veljajo v javnem izobraževalnem sistemu in mednarodnem okolju« (str. 39). Ne smemo zanemariti dejstva, da članstvo države v Natu in EU od vojske zahteva tudi sposobnosti za delovanje v mednarodnih vojaških strukturah in zato tudi kompetence častnikov, ki so primerljive s tujimi. Dodati je treba tudi, da so zahodne vojske v procesu ene najbolj intenzivnih transformacij v novejši zgodovini, zato so danes pred številnimi izzivi na področju izobraževanja častnikov.

Potrebe po mednarodni primerljivosti se pri nas zavedamo, vendar gre pri razpravah o izobraževanju pogosto za nezadostno poznavanje razvojnih trendov in dilem, s katerimi se srečujejo v zahodnih državah. V prispevku bomo poskušali prikazati temeljne dileme glede prilagajanja šolanja častnikov sodobnim zahtevam in različne pristope k šolanju v državah članicah EU. Prikaz bo omejen na raven temeljnega šolanja častnikov kopenske vojske, ki ga na splošno razumemo kot tisto fazo šolanja, ki se zaključi s pridobitvijo prvega častniškega čina. V zaključnem delu prispevka bomo prevladujočo prakso evropskih držav poskušali primerjati s slovenskim modelom šolanja častnikov in predstaviti nekaj razmislekov glede šolanja $\mathrm{v}$ prihodnje.

\footnotetext{
Uporabljamo izraz šolanje, ki združuje izobraževanje in usposabljanje ter ga razumemo kot formalno organizirano obliko v primerjavi s samoizobraževanjem.

2 Srednjeročni obrambni program Republike Slovenije, 17. 2. 2016, Vlada RS.
} 


\section{1 ŠOLANJE ČASTNIKOV - IZOBRAŽEVANJE IN/ALI USPOSABLJANJE}

$\mathrm{Na}$ splošno v sodobnem svetu velja, da mora šolanje častnikov zagotoviti dovolj široko izobrazbo in sposobnost nadgrajevanja znanja, hkrati pa bodoče častnike pripraviti tudi za učinkovito delo po prihodu na častniško dolžnost. Obsegati mora torej teoretično in veščinsko komponento. V sodobnih vojskah proces izobraževanja in usposabljanja (angl. education and training) pogosto obravnavajo kot celovit proces priprave kadra. Ker pa so častniki nosilci vojaške profesije, vsako profesijo pa opredeljuje specifični nabor teoretičnega znanja, je zelo pomembna prav izobraževalna komponenta. Foot (2006, str. 14) meni, da se meje med izobraževanjem in usposabljanjem (in tudi definicije) prekrivajo. Vendar pa na teoretični ravni značilnosti ene in druge komponente pogosto metaforično označujejo s špartanskim in atenskim pristopom k šolanju častnikov. Špartanski pristop je mogoče enačiti z usposabljanjem; zagotavlja poznavanje znanih dejstev in temelji na vrednotah, kot so disciplina, samožrtvovanje, vrednotenje tehnologije, patriotizem, čast in herojstvo. Atenski pristop predstavlja izobraževanje; zagotavlja orodja, s katerimi se je mogoče spopadati z neznanim, in temelji na vrednotah, kot so učenje, kreativno in kritično razmišljanje, vrednotenje filozofije in zgodovine, medkulturno razumevanje ter postherojstvo. ${ }^{3}$ Šolanje častnikov je vedno zmes obeh pristopov. Z višjo ravnjo izobraževanja med kariero je vse bolj pomemben drugi pristop. Vendar tudi sodobne zahteve, glede na vedno bolj neznane izzive, s katerimi se bodo spoprijemali častniki, vedno bolj zahtevajo atenski pristop (prav tam, str. 15).

Razumevanje procesov izobraževanja in usposabljanja ali atenskih in špartanskih značilnosti šolanja častnikov je zelo pomembno zaradi spremenjenih zahtev, ki se postavljajo pred častniško profesijo. V teoriji najdemo različne opredelitve obeh procesov, vendar je razlikovanje med izobraževanjem in usposabljanjem pri vseh precej podobno (tabela 1).

Podobno Paile (2011, str. 17) navaja razlikovanje med razumevanjem častnikov kot »elitnih vojakov« ali »špartancev« in kot »strategov« ali »atencev«. 
Tabela 1:

Razumevanje izobraževanja

in usposabljanja na vojaškem področju

\begin{tabular}{|l|l|}
\hline Izobraževanje (Education) & Usposabljanje (Training) \\
\hline \multicolumn{2}{|l|}{ International Military and Defence Encyclopedia, 1993, str. 804-5 } \\
\hline $\begin{array}{l}\text { Vojaško izobraževanje je sistematično poučevanje } \\
\text { posameznikov, ki povečuje njihovo poznavanje } \\
\text { znanosti in veščine vojskovanja. Izobraževanje je } \\
\text { usmerjeno na posameznike. }\end{array}$ & $\begin{array}{l}\text { Usposabljanje je poučevanje osebja za krepitev } \\
\text { in urjenje ene ali več enot za krepitev bojne } \\
\text { sposobnosti. Usmerjeno je bodisi na posameznika } \\
\text { ali enoto. }\end{array}$ \\
\hline
\end{tabular}

Žabkar in Svete, 2008, str. 188

Izobraževanje se nanaša na načrtno poučevanje posameznikov na področjih, s katerimi poglabljajo znanje iz domene znanosti in veščine vojskovanja. Prispeva k pridobivanju znanj in razumevanju vojaških procesov, kar je pogoj za presojo razmer in sprejemanje racionalnih odločitev. Je teoretsko naravnano (vključuje opisovanje, klasificiranje, interpretacijo in predvidevanje). Povezano je s posameznikom.

Vojaško usposabljanje je proces pripravljanja posameznikov ali enot na uspešno opravljanje konkretnih nalog v vojni. Razvijajo se praktično akcijsko znanje in veščine. Je večdimenzionalno, poleg posameznika lahko zajema tudi štabe, enote in skupine.

Education and Training Directive - Bi-SC 75-2, Nato, 2013, str. 9

Sistematično poučevanje posameznikov $v$ predmetih, ki povečuje njihovo znanje in spretnosti ter razvija kompetence.
Individualno usposabljanje: vse aktivnosti poučevanja, ki zagotavljajo znanje, spretnosti in kompetence, potrebne za opravljanje dodeljene dolžnosti.

Kolektivno usposabljanje: urjenje postopkov in praktično izvajanje doktrine, načrtov in postopkov za doseganje in ohranjanje taktičnih, operativnih in strateških zmogljivosti.

Officer Professional Military Education Policy, (Enc. A, e), ZDA, 2015

Izobraževanje večinoma poteka na kognitivnem področju in razvija širino in različnost pogledov, sposobnost kritične analize in abstraktnega razmišljanja v razmerah nejasnosti in negotovosti ter inovativnega razmišljanja, posebej ob kompleksnih in nelinearnih problemih.
Usposabljanje je usmerjeno predvsem na psihomotorično področje, in sicer s poučevanjem osebja za povečanje sposobnosti izvajanja konkretnih funkcij in nalog.

Doktrina vojaškega izobraževanja in usposabljanja, Slovenija, 2013, str. 7

Pri vojaškem izobraževanju je pomembno s teoretičnim znanjem in spoznavanjem etičnih načel in standardov, ki oblikujejo dobrega vojaka, utrjevati integriteto posameznika.
Pri vojaškem usposabljanju sta v ospredju razvijanje praktičnega znanja, veščin in postopkov ravnanja, pridobljenega predvsem z urjenjem, ter oblikovanje posebnih sposobnosti, značajskih in moralnih lastnosti.

MacAllister, navedno v McCausland in Martin, 2001

Izobraževanje je usmerjeno k bolj splošnemu in abstraktnemu znanju, ki je lahko ali pa tudi ni povezano s specifično nalogo in aktivnostjo.

Usposabljanje je usmerjeno k razvoju in sposobnosti opravljanja konkretnih nalog ali spretnosti. 
Iz navedenih pogledov na izobraževanje in usposabljanje je mogoče razbrati, da gre za razlike tako glede vsebine kot ciljev obeh procesov. Izobraževanje razumemo kot dejavnost, usmerjeno $\mathrm{v}$ domeno teorije in bolj abstraktnega razmišljanja, usposabljanje pa je bolj usmerjeno na konkretne sposobnosti za neko delo ali funkcijo oziroma na praktične postopke. Izobraževanje je usmerjeno v razvoj sposobnosti za reševanje problemov, usposabljanje pa v izvajanje rutinskih postopkov. Posledično izobraževanje razvija sposobnosti za reševanje novih, nepredvidljivih problemov, usposabljanje pa sposobnosti za odzivanje $\mathrm{v}$ vnaprej predvidenih situacijah. Izobraževanje je vedno usmerjeno k posamezniku, usposabljanje pa k posamezniku ali skupini oziroma enoti.

$\mathrm{Na}$ splošno različne poklicne dejavnosti zahtevajo različen obseg predhodnega izobraževanja ali usposabljanja oziroma je razmerje med tema sestavinama različno. Tudi za vojaške poklice lahko trdimo enako, vojaki se predvsem usposabljajo, tako individualno kot skupinsko, za častniški kader pa je pomembno, da se ob usposabljanju za opravljanje dolžnosti zagotovi tudi ustrezno izobraževanje. Pri šolanju častnikov gre za povezanost obeh procesov, jasno ločnico med njima pa je težko postaviti. Nekateri avtorji tudi menijo, da je usposabljanje del izobraževanja. Kramar (1996, str. 16) trdi, da »usposabljanje ni celoten proces pridobivanja znanja, razvijanja spretnosti, sposobnosti in navad vojaškega delovanja, temveč pomembna sestavina procesa izobraževanja in usposabljanja«. Danes je vojaško osebje pravzaprav vse bolj soočeno s potrebo po izobraževanju in ne le usposabljanju.

Pravzaprav se vse profesije, ne le vojaška, srečujejo s problemom razmerja med širšim, bolj abstraktnim izobraževanjem in usposabljanjem za konkretno delo. Kot meni Svetlik, ki ga navaja Kotnik (2012, str. 21), se danes profesije spoprijemajo s hitrimi spremembami, zaradi katerih je vse manj mogoče in smiselno nove pripadnike usposabljati za opravljanje konkretnih profesionalnih nalog v začetnem izobraževanju. Namesto tega predlaga, naj bo izobraževanje začetnikov čim bolj usmerjeno v pridobivanje splošnih in široko uporabnih sposobnosti in znanja, kar bo zagotavljalo dobro podlago za poznejše sprotno prilagajanje spreminjajočemu se profesionalnemu delu.

Munnik (2012, str. 461) opozarja, da se danes večina vojaških institucij ukvarja z vprašanjem, koliko je v izobraževanje vojaškega osebja treba vključevati akademski pristop. Še posebej po hladni vojni je v razpravah o šolanju častnikov vse bolj prisotno prepričanje, da ti potrebujejo široko izobrazbo. Tradicionalno je veljalo, da mora temeljno šolanje častnikov zagotoviti sposobnost opravljanja prve dolžnosti v častniški karieri, širšo in bolj strateško usmerjeno izobrazbo pa častniki pridobivajo na višjih ravneh šolanja $v$ času svoje kariere ${ }^{4}$ Danes se tudi na področju vojaške profesije pojavlja vse več razprav o tem, da je treba častnikom že v začetnih fazah

4 Pri tem gre za različne oblike štabnega in generalštabnega šolanja, ki so pogoj za doseganje višjega čina oziroma za delo na višjih poveljniških ravneh. 
šolanja zagotoviti bolj široko in abstraktno znanje, kar pa pomeni spremembo razmerja med izobraževanjem in usposabljanjem.

Kotnik (2012, str. 21) meni, da vojaškega osebja »zgolj urjenje in usposabljanje, brez ustreznega izobraževanja, dolgoročno gledano ne bosta več zadovoljivo opremili s potrebnimi kompetencami za izvedbo nalog v vse bolj zapletenem in za napake zelo občutljivem okolju«. Podobno Johnson-Freese (2013, str. 204-5) meni, da je treba, če želimo doseči premik k bolj transformativnemu izobraževanju, ${ }^{5}$ najprej sprejeti dejstvo, da je razlika med izobraževanjem in usposabljanjem, nato pa se od nagnjenosti k usposabljanju preusmeriti k prevladi izobraževanja. Poklicno vojaško izobraževanje častnikov, meni, mora preseči usmerjenost le na usposabljanje, ki je sicer inherentno njegov del:

Združeno vojaško profesionalno izobraževanje $(J P M E)^{6}$ presega usposabljanje s tem, ko dodaja razumevanje konteksta, kar omogoča optimalno usposabljanje. Enako, če ne celo bolj pomembna je pedagoška razlika med usposabljanjem in izobraževanjem. Uspešnost programov usposabljanja je lahko meriti, ker se učimo o pravih in napačnih metodah in odgovorih. Ko gre za izobraževanje, pa je merjenje uspeha manj jasno in težje, ker se izobraževanje umerja na vprašanje, kako razmišljati, ne kaj razmišljati, zahteva čas za študij in razmišljanje in pogosto ne nudi pravih ali napačnih odgovorov [poudarek je izviren].

Šolanje častnikov je po mnenju iste avtorice tudi sicer treba čim bolj približati standardom, ki veljajo v civilnem šolstvu. Pri tem je treba zagotavljati: 1) akademsko svobodo v smislu dopuščanja obravnave različnih pogledov $\mathrm{v}$ izobraževalnem procesu; 2) kakovosten predavateljski kader, ki posreduje ustrezna profesionalna znanja in izkušnje in je sposoben v poučevanje vključevati tudi transformativne izzive; 3) relevantne učne programe.

Paile (2011, str. 11) v svoji analizi šolanja častnikov v evropskih državah opozarja na pomen doseganja fleksibilnosti in širine razmišljanja že med šolanjem. Za to si je treba prizadevati že kolikor je mogoče zgodaj v procesu šolanja, saj se bodo mnogi častniki že v začetku svoje kariere srečali z mednarodnimi razsežnostmi svojega poklica. Tudi ameriška avtorja McCausland in Martin (2001) ugotavljata, da se že mlajši častniki pogosto znajdejo v nejasnih in kompleksnih razmerah delovanja, ki zahtevajo več intelekta, pobude in sposobnosti vodenja, kot je to veljalo v hladni vojni. V resnici se zmanjšujejo razlike med taktično, operativno in strateško ravnjo vojskovanja. Takšne razmere lahko odkrijemo v delovanju, ki ga v Natu imenujemo »operacije kriznega odzivanja«, vedno bolj verjetne pa so tudi z vse večjo prisotnostjo hibridnih oblik vojskovanja. To pomeni, da bodo že častniki na nižji ravni morali sprejemati odločitve, ki imajo operativne ali strateške posledice.

\footnotetext{
5 Po mnenju avtorice je transformativno izobraževanje usmerjeno $v$ širjenje znanja in pogledov posameznika za doseganje večje »intelektualne agilnosti«.

${ }^{6}$ Joint Professional Military Education.
} 
Temu je treba prilagoditi tudi šolanje častnikov že na temeljni ravni, kar pomeni, da jih je treba opremiti z abstraktnim profesionalnim znanjem, ki ga lahko uporabijo v določeni situaciji. Častnikom je treba zagotoviti »razumevanje temeljnih strateških konceptov že bolj zgodaj v njihovi karieri« (prav tam: 19). Takšne priprave zahtevajo izobraževanje na področjih zgodovine, političnih znanosti, ekonomije, regionalnih in kulturoloških študij, etike in varnostnih zadev (prav tam: 22). Menita, da je široko teoretično izobrazbo častnikom treba zagotavljati že od začetka šolanja, to pa je podlaga, na kateri se gradi njihovo nadaljnje izobraževanje med kariero. Ocenjujeta, da je praksa, ko poskušajo častnike šele po 20 letih kariere na desetmesečnem najvišjem vojaškem šolanju preobraziti iz »taktikov in operativcev v stratege«, nezadostna in neustrezna, če želimo, da bodo častniki sposobni ustrezno opravljati svoje dolžnosti (prav tam: 24).

Ustrezna izobrazba častnikov ni pomembna le za kakovostno izvajanje neposrednih nalog vojske v zagotavljanju varnosti in obrambe. Povezana je tudi z obstojem vojske kot družbene institucije in njeno vlogo v družbenem okolju. Foot (2006, str. 18) navaja, da ustrezno izobraževanje vpliva na preprečevanje teh pojavov:

- upadanje kakovosti »vojaškega nasveta«, ki ga vojska zagotavlja političnemu vodstvu, ter hkrati poslabšanje podobe o učinkovitosti vojske in povečevanje prepada med njo in civilnim uradništvom na obrambnih in zunanjih ministrstvih;

- zmanjševanje primerljivosti s častniškim zborom zavezniških držav in posledično manj možnosti za pridobivanje poveljniških dolžnosti v tujini;

- povečanje izoliranosti vojske $\mathrm{v}$ družbi, slabšanje njene podobe ter nižanje standardov za vstop v častniški poklic;

- frustracije sposobnih častnikov, ki se kažejo v težnji po predčasnem odhodu iz vojske in zmanjšanju njihove motivacije za poučevanje v vojski.

Hkrati Foot (2006, str. 19) meni, da izobraževanje ne sme temeljiti le na zahtevah dolžnosti, ki jo bodo častniki opravljali neposredno po nekem šolanju, temveč mora zagotavljati višjo stopnjo profesionalnosti in intelektualni razvoj. Navedena razmišljanja kažejo na širok pomen izobraževanja častnikov; poleg zagotavljanja vojaške učinkovitosti je to pomembno tudi za odnos vojske s političnimi strukturami ter civilno družbo v lastni državi in z zavezniškimi ali partnerskimi vojskami v tujini oziroma za status in ugled vojske doma in v tujini.

\section{MODELI ŠOLANJA ČASTNIKOV V EVROPSKIH DRŽAVAH}

Izobraževanje in poklicno delo častnikov je tudi $\mathrm{v}$ današnjem času trdno vpeto $\mathrm{V}$ državne okvire. V tem se razlikuje od večine drugih profesij in poklicev, pri katerih se povečuje mobilnost na področju izobraževanja in zaposlovanja. Pripadniki številnih profesij danes najdejo zaposlitev v drugih državah, ne v tistih, v katerih so pridobili 
svojo izobrazbo. V EU je takih sedem odstotkov od vseh zaposlenih. ${ }^{7}$ Taka mobilnost je vse bolj značilna tudi za visoko izobražen kader, ki se seli praviloma v države, ki ponujajo bolj perspektivno okolje. V zvezi z mobilnostjo visoko izobraženega kadra pogosto govorimo o begu možganov, ki tudi v Sloveniji ni nepoznan. Vendar pa omenjeni trend ne velja za vojaško profesijo. Čeprav ta spada med tiste, ki so danes najbolj odprte $»$ mednarodnim realnostim $\ll^{8}$ (Paile, 2011, str. 11), se častniki izobražujejo v državi, v kateri opravljajo tudi svoj poklic, v času kariere pa nimajo možnosti mobilnosti med državami. V redkih primerih najdemo odstopanja, ki pa so posledica izjemnih situacij. ${ }^{9}$

Za častniško profesijo je značilno, da ima vsaka država izključno odgovornost za šolanje svojih častnikov. V primerjavi z drugimi profesijami zelo načrtno skrbijo za pridobivanje in njihovo izobraževanje. Načini in vsebine šolanja so specifični za vsako državo, opredeljeni s potrebami, kot jih država definira, s tradicijo, kulturo, vrednotami, značilnostmi vojaške organizacije, vojaško doktrino idr. Šolanje praviloma poteka v specializiranih ustanovah (fakultetah, akademijah), ki so del vojaških oziroma obrambnih struktur države ali pa so z njimi tesno povezane. Ponekod izobraževanje častnikov poteka tudi v povezavi s civilnimi izobraževalnimi institucijami, vendar pa sta vloga in vpliv vojsk v izobraževanju častnikov odločilna. Vojska ni le »delodajalec« častniškemu kadru, ampak tudi oblikuje zahteve in izvaja izobraževalni proces častnikov; je hkrati njihov »preskrbovalec in uporabnik« (provider and end-user) (Paile, 2011, str. 30).

Ob siceršnji organizacijski in vsebinski raznolikosti šolanja častnikov v državah članicah EU so zelo redke primerjalne analize šolanja, na sploh pa je to redko predmet bolj celovite teoretične obravnave. Nekoliko več pozornosti so temu začeli posvečati v okviru zamisli o projektu Vojaški Erasmus (Military Erasmus), ki naj bi okrepil izmenjavo šolajočih se in učiteljev med vojaškimi šolami članic EU. Zato se je začela izmenjava informacij, na podlagi katere je leta 2011 nastala publikacija »Compendium of the European Military Officers Basic Education« (urednik S. Paile). Gre za analizo temeljnih značilnosti šolanja častnikov in je prvi tovrstni pregled na ravni EU.

Primerjava uveljavljenih modelov pokaže na različne oblike temeljnega šolanja častnikov. Medtem ko je šolanje povsod sestavni del pridobivanja častniškega

\footnotetext{
Po podatkih EUROSTAT-a je bilo leta 2012 v EU 15,2 milijona ljudi zaposlenih zunaj države rojstva. Od tega jih 6,6 milijona prihaja iz druge članice EU, 8,6 milijona pa iz države nečlanice. Vletih 2011 in 2012 je državo zaposlitve spremenilo en milijon ljudi. Največ prihodov so ugotovili v Veliki Britaniji, Nemčiji, Španiji, Franciji, Avstriji in Italiji. V primerjavi z letom 2010 gre za 6,5-odstotni porast zaposlitev v drugi državi. http:// ec.europa.eu/eurostat/statistics-explained/index.php/Archive:Labour_force_survey_overview_2012 (8. 7. 2016)

$\&$ Predvsem zaradi pogostega opravljanja dela v mednarodnem okolju in potrebe po sodelovanju s pripadniki drugih vojsk. Vojaške operacije so danes multilateralne in potekajo v okoljih, ki so bistveno drugačna od domačega okolja pripadnikov vojske.

9 Tako na primer med državami, vključenimi v analizo, Ciper, Luksemburg in Malta nimajo vojaških izobraževalnih institucij in častnike šolajo v tujini. Do izjem pride tudi pri razpadu in nastajanju novih držav, kot so na primer Sovjetska zveza, Jugoslavija in Nemška demokratična republika, v katerih so častniki vstopili v vojske novih ali drugih držav.
} 
kadra, je že odnos med šolanjem in pridobitvijo čina različen. Ponekod šolajoči se dobijo častniški čin že med šolanjem, drugje šele po zaključku (Paile, 2011, str. 17). Razlikujeta se tudi dolžina šolanja bodočih častnikov in stopnja zahtevane izobrazbe za podelitev častniškega čina. Vsi programi šolanja častnikov vsebujejo bolj splošne oziroma civilnim programom podobne vsebine (tehnične in družboslovne) in tudi bolj vojaško naravnane vsebine ter praktično usmerjeno usposabljanje za poklic častnika. Razmerje med temi vsebinami se v državah razlikuje.

Splošni trend v Evropi in na Zahodu je težnja za povečevanje »intelektualne legitimnosti« častnikov, ki je posledica spremenjenih nalog vojsk po koncu hladne vojne, pa tudi potrebe po zagotavljanju ustrezne izobrazbe, ki častnikom ob odhodu iz vojske omogoča zaposlovanje v civilni sferi (prav tam, str. 20). Skladno s tem se šolanje častnikov približuje značilnostim univerzitetnega izobraževanja, institucije, ki ga izvajajo, pa so podobne drugim univerzitetnim ustanovam. To vključuje tudi uveljavljanje načel Bolonjske deklaracije $\mathrm{v}$ delovanju vojaških izobraževalnih institucij.

Omenjena analiza je ponudila tudi analitični model, ki poskuša prikazati temeljne sestavine šolanja častnikov. Te so: a) razvoj sposobnosti voditeljstva - leadership; b) univerzitetno izobraževanje - academic education; c) poklicno usposabljanje vocational training (shema 1). Zagotavljanje sposobnosti voditeljstva je temeljni cilj izobraževanja in usposabljanja častnikov tako v fazi temeljnega kot nadaljevalnega šolanja, zato v analizi tudi ni obravnavano kot sestavina sama po sebi, je namreč rezultat šolanja in temeljna kompetenca častnikov. Voditeljstvo tudi ni nujno predmet, ki se poučuje v procesu šolanja; razvoj voditeljskih sposobnosti je v bistvu vpet $\mathrm{v}$ celoten proces izobraževanja.

Shema 1: Analitični prikaz sestavin izobraževanja in usposabljanja častnikov

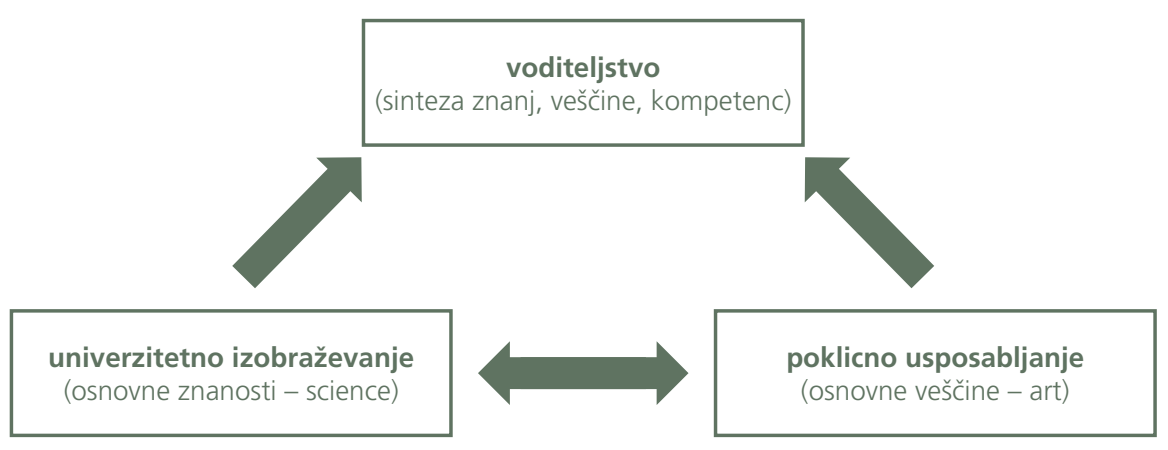

Temeljni sestavini ali stebra, na katerih temelji šolanje častnikov, sta univerzitetno izobraževanje in poklicno usposabljanje. $\mathrm{V}$ različnih razmerjih sta prisotna $\mathrm{V}$ vseh obravnavanih sistemih šolanja ter skupaj zagotavljata potrebne kompetence 
častnikov (shema 2). Kombinacija navedenih dveh elementov kaže kompleksno naravo opravljanja vojaške profesije, ki jo pogosto označujemo z dvojnostjo, izraženo $\mathrm{v}$ znanosti in veščini (angl. science and art). Medtem ko zasidranost v področje znanosti zahteva analitične in konceptualne pristope, so na področju veščine ključni praktični pristopi, kar pomeni, da so za častnike potrebni širše teoretično znanje in analitične sposobnosti, na področju veščine pa sposobnost aplikacije tega znanja $\mathrm{v}$ konkretne uporabne rezultate.

\begin{tabular}{|c|c|c|}
\hline $\begin{array}{r}\text { Shema 2: } \\
\text { Temeline }\end{array}$ & \multicolumn{2}{|c|}{ Izobraževanje in usposabljanje častnikov } \\
\hline $\begin{array}{l}\text { sestavin izobraže- } \\
\text { vanja in usposa- } \\
\text { bljanja častnikov }\end{array}$ & $\begin{array}{l}\text { univerzitetno izobraževanje } \\
\text { (academic education) }\end{array}$ & $\begin{array}{l}\text { poklicno usposabljanje } \\
\text { (vocational training) }\end{array}$ \\
\hline & $\begin{array}{l}\text { - namen: zagotavljanje širšega } \\
\text { teoretičnega znanja in diplome } \\
\text { 1. ali 2. bolonjske stopnje } \\
\text { - izvajalci: univerze, akademije } \\
\text { - vrednotenje s kreditnimi } \\
\text { točkami: da } \\
\end{array}$ & $\begin{array}{l}\text { - } \text { namen: zagotavljanje } \\
\text { specifičnega znanja za dolžnost } \\
\text { v rodu/službi } \\
\text { - izvajalci: centri za usposabljanje } \\
\text { (application schools) } \\
\text { - vrednotenje s kreditnimi }\end{array}$ \\
\hline
\end{tabular}

Ob sicer zelo različnih vsebinah in oblikah temeljnega šolanja častnikov lahko ugotovimo, da je to povsod sestavljeno iz univerzitetnega izobraževanja in poklicnega usposabljanja. Univerzitetno izobraževanje praviloma ni neposredno namenjeno zagotavljanju sposobnosti za opravljanje častniške dolžnosti, temveč zagotavlja širše in bolj abstraktno znanje in častnike tudi usposobi za nadaljnje učenje med kariero. Pogosto se častniki različnih rodov in služb izobražujejo na istih univerzitetnih programih. Konkretno znanje in sposobnosti za opravljanje prve dolžnosti pa častniki pridobijo v različnih oblikah poklicnega usposabljanja.

Univerzitetno izobraževanje obsega programe na področjih, ki so podobna programom civilnih izobraževalnih ustanov (tehniškim in družboslovnim) oziroma zagotavlja širše in bolj teoretično usmerjeno znanje. Zagotavlja tudi kreditne točke in diplomo 1. ali 2. bolonjske stopnje. To izobraževanje večinoma izvajajo obrambne univerze ali vojaške akademije, v nekaterih primerih poteka v sodelovanju s civilnimi institucijami; ponekod, na primer v Veliki Britaniji in Sloveniji, častniki pridobijo univerzitetno izobrazbo v civilnih izobraževalnih ustanovah. Povsod pa sta javno priznana diploma prve ali druge bolonjske stopnje in ustrezen naziv (Bachelor of Arts ali Master of Arts) glede na program, ki ga častniki zaključijo. V tabeli 2 so prikazani temeljni podatki o izvajanju univerzitetnih programov v izbranih državah. ${ }^{10}$

\footnotetext{
${ }^{10}$ Skupaj je bilo v analizo vključenih 23 držav-članic EU, ki izvajajo šolanje častnikov. Ker bi bilo prikazovanje vseh primerov $v$ članku preobsežno, smo izbrali nekaj držav; z izborom želimo predstaviti predvsem različne modele šolanja. Celoten pregled je predstavljen v Paile, 2011, str. 53-225.
} 


\begin{tabular}{|c|c|c|c|}
\hline \multirow{13}{*}{$\begin{array}{r}\text { Tabela 2: } \\
\text { Izbrani primeri } \\
\text { temeljnega } \\
\text { šolanja častnikov } \\
\text { kopenske vojske - } \\
\text { univerzitetni } \\
\text { programi } \\
\text { Vir: Paile, } 2011 .\end{array}$} & Država & Stopnja - trajanje & Nazivi programov \\
\hline & Avstrija & Visoka - 3 leta & Vojaško voditeljstvo \\
\hline & Belgija & Magisterij stroke - 5 let & Družbene in vojaške znanosti, Tehnične znanosti \\
\hline & Bolgarija & Visoka - 5 let $^{11}$ & $\begin{array}{l}\text { Regionalna in nacionalna varnost, Logistika, Upravljanje virov } \\
\text { in tehnologije, Inženirstvo in tehnologija (različnih smeri), } \\
\text { Zaščita prebivalstva ob katastrofah }\end{array}$ \\
\hline & Češka & Visoka - 3 leta & $\begin{array}{l}\text { Vojaški menedžment in ekonomika nacionalne obrambe, } \\
\text { Vojaška tehnologija }\end{array}$ \\
\hline & Italija & Magisterij stroke - 5 let & $\begin{array}{l}\text { Strateške in politične znanosti, Strateške in infrastrukturne } \\
\text { znanosti, Strateške in komunikacijske znanosti, Strateške in } \\
\text { logistične znanosti, Inženirstvo (različnih smeri) })^{12}\end{array}$ \\
\hline & Madžarska & Visoka - 5 let & $\begin{array}{l}\text { Vojaško voditeljstvo, Vojaška ekonomika, Vojaški in varnostni } \\
\text { inženiring }\end{array}$ \\
\hline & Nemčija & $\begin{array}{l}\text { Magisterij } \\
\text { stroke }-4 \text { leta }^{13}\end{array}$ & $\begin{array}{l}\text { Pedagoške znanosti, Ekonomske znanosti, Družbene } \\
\text { znanosti, Inženirstvo (različnih smeri) }\end{array}$ \\
\hline & Nizozemska & Visoka - 4 leta & $\begin{array}{l}\text { Vojaške znanosti, Poslovna in javna uprava, Komunikacije, } \\
\text { Informatika in sistemi kontrole in poveljevanja, Vojaški sistemi } \\
\text { in tehnologija, Civilno inženirstvo }\end{array}$ \\
\hline & Poljska & Visoka - 4 leta & Menedžment, Nacionalna varnost \\
\hline & Slovaška & Visoka - 3 leta & $\begin{array}{l}\text { Strojno inženirstvo, Računalniško inženirstvo, Elektro } \\
\text { inženirstvo, Vojaški menedžment }\end{array}$ \\
\hline & Slovenija & Visoka - 3 ali 4 leta & Različne smeri civilnih fakultet \\
\hline & Velika Britanija & $\begin{array}{l}\text { Visoka (praviloma) - } \\
\text { in } 1 \text { leto poklicnega } \\
\text { usposabljanja }\end{array}$ & Različne smeri civilnih fakultet \\
\hline
\end{tabular}

V državah članicah EU izobraževanje častnikov kopenske vojske poteka na zelo različnih programih. Enoten program za vse častnike ima od prikazanih držav samo Avstrija, sicer pa še Španija, Latvija in Estonija. V vseh drugih državah izvajajo več programov, tako tehničnih kot družboslovnih usmeritev. Skladno s tem častniki po končanem izobraževanju dobijo tudi različne univerzitetne nazive. Programi izobraževanja imajo večinoma 'civilni značaj' in se izvajajo po istih kriterijih kot univerzitetni študij na civilnih fakultetah. Ponekod, na primer na Poljskem, so tovrstni programi odprti tudi za študente, ki se ne šolajo za častnike.

"I Prvo bolonjsko stopnjo (BA) bodoči častniki v nekaterih državah dosežejo šele po petih letih, ker študij združuje akademsko izobraževanje in poklicno usposabljanje.

${ }_{12}$ Najpogosteje so to: strojno inženirstvo, elektro inženirstvo, gradbeno inženirstvo, industrijsko inženirstvo, računalniško inženirstvo in telekomunikacijsko inženirstvo.

${ }_{13}$ V Nemčiji se častniki na prvo dolžnost pripravljajo šest let, ker je univerzitetnemu izobraževanju dodano še temeljno vojaško in poklicno usposabljanje. Univerzitetno izobraževanje poteka na dveh akademijah Zvezne vojske, in sicer v Hamburgu in Münchnu. 
Povsod je univerzitetna izobrazba tudi pogoj za vstop v častniške vrste. Izjema je Velika Britanija, v kateri imajo lahko častniki tudi nižjo stopnjo izobrazbe, vendar spodbujajo študij častnikov in ti večinoma že med kariero dosežejo univerzitetno izobrazbo. Stopnja univerzitetne izobrazbe, ki jo morajo častniki doseči med temeljnim šolanjem, je različna; med prikazanimi primeri vidimo, da je v Belgiji, Italiji in Nemčiji to magisterij stroke, v drugih državah pa visoka izobrazba oziroma prva bolonjska stopnja. Tudi trajanje šolanja se razlikuje, celo takrat, ko gre za doseganje enake stopnje izobrazbe. To je predvsem posledica dejstva, da v nekaterih državah v izvajanje univerzitetnih programov vključujejo poklicno usposabljanje, kar podaljša čas šolanja. Poleg univerzitetnega izobraževanja morajo bodoči častniki praviloma opraviti še temeljno vojaško usposabljanje in poklicno usposabljanje, ki lahko traja od 6 do 24 mesecev; tako da celotno šolanje častnikov traja od 4 do 6 let.

Poklicno usposabljanje je druga sestavina šolanja častnikov. Je praktični vidik tega procesa in bodoče častnike usposablja za opravljanje konkretne dolžnosti, ki jo bodo prevzeli po končanem šolanju. Oblike in načini izvajanja usposabljanja so v posameznih državah še bolj različni kot izvajanje univerzitetnega izobraževanja. Praviloma poteka v institucijah, ki so ločene od univerz ali akademij, ter povezane s specifičnimi rodovi ali službami. To usposabljanje ni v vseh državah ovrednoteno s kreditnimi točkami, torej nima statusa univerzitetnega izobraževanja. Od 23 držav, vključenih $\mathrm{v}$ analizo, jih samo osem priznava kreditne točke. ${ }^{14}$ Poklicno usposabljanje je tudi zelo različno umeščeno v potek šolanja. Ponekod poteka vzporedno z univerzitetnim programom, drugje samo v določenih obdobjih šolskega leta, ponekod pa je umeščeno na konec šolanja. Znatne razlike med državami so tudi glede povezanosti univerzitetnega izobraževanja in poklicnega usposabljanja - ti dve sestavini nekateri razumejo kot popolnoma ločeni, spet drugi pa kot povezani sestavini enotnega procesa. Nabor programov poklicnega usposabljanja je odraz potreb po častnikih $\mathrm{v}$ rodovih in službah kopenske vojske, ki jih država razvija. Najbolj na splošno častnike kopenske vojske umestijo v eno izmed naslednjih oblik usposabljanja: pehota, artilerija, inženirstvo, oklepne in mehanizirane enote, RKBO, informatika in komunikacije, logistika, izvidništvo, zračna obramba in letalstvo kopenske vojske.

Razločevanje med univerzitetnim izobraževanjem in poklicnim usposabljanjem se med državami razlikuje. Ponekod med obema poteka stroga ločnica. Usposabljanje konceptualno ni del univerzitetnega izobraževanja in je tudi časovno ločeno od slednjega. Izvaja se na primer po koncu izobraževanja ali $\mathrm{v}$ posebnih terminih znotraj študijskega leta, na primer v poletnih mesecih ali obdobjih med študijskimi semestri. Usposabljanje je lahko konceptualno integrirano v proces univerzitetnega izobraževanja oziroma časovno vzporedno. Paile (2011, str. 31-2) glede na te razlike modele šolanja klasificira na tri osnovne tipe: sestavini sta organsko ločeni, potekata izmenično oziroma paralelno. Razlike ostajajo tudi glede ovrednotenja posameznih sestavin šolanja s kreditnimi točkami. Medtem ko je univerzitetni program praviloma

${ }^{14}$ Bolgarija, Estonija, Francija, Madžarska, Italija, Latvija, Španija in Švedska. 
povsod vrednoten s kreditnimi točkami, pa v manj kot polovici držav kreditne točke dodeljujejo tudi za poklicno usposabljanje.

Na podlagi prikazane analize lahko strnemo naslednje ugotovitve glede organizacijskih in vsebinskih vidikov šolanja častnikov. Organizacijske rešitve se v državah zelo razlikujejo, kar se kaže $\mathrm{v}$ dolžni šolanja in stopnji pridobljene izobrazbe, različni stopnji sodelovanja s civilnimi institucijami, časovnem zaporedju univerzitetnega izobraževanja in poklicnega usposabljanja ter kreditnem vrednotenju poklicnega usposabljanja. Gledano $\mathrm{z}$ vsebinskega vidika ugotovimo veliko raznolikost univerzitetnih programov in programov poklicnega usposabljanja. Podobnosti se kažejo v zahtevi po univerzitetni izobrazbi častnikov; v konceptualnem ločevanju med univerzitetnim izobraževanjem in poklicnim usposabljanjem; v težnji, da se častnikom zagotovita široko znanje in sposobnost prilagajanja hitro spreminjajočim se zahtevam profesije ter $\mathrm{v}$ približevanju značilnostim javnega univerzitetnega izobraževanja. Večina držav ima večje število različnih programov univerzitetnega izobraževanja, s čimer zagotavljajo ustrezno znanje častnikov za posamezne rodove in službe.

\section{EVROPSKA PRAKSA IN SLOVENSKI MODEL ŠOLANJA ČASTNIKOV}

Čeprav vojske držav članic EU vse več nalog izvajajo v večnacionalnih sestavah in se vojaško sodelovanje med državami povečuje, pa temeljno izobraževanje častnikov ostaja odgovornost in pristojnost držav. Razlike glede vsebin, predvsem pa glede načinov šolanja so precejšnje; vsaka država organizira šolanje, ki najbolj ustreza njenim potrebam, zmogljivostim in družbenemu okolju. Šolanje si povsod prizadevajo prilagoditi vse bolj kompleksnim zahtevam vojaške profesije. Narava vojaške profesije določa vsebino izobraževanja, hkrati pa je izobraževanje eden izmed njenih temeljnih sestavnih elementov. Potočnik (2012, str. 34-5) kot ključne značilnosti, ki predstavljajo temelje sodobne vojaške profesije, navaja odnos zaupanja in službe med vojaškimi profesionalci ter civilno družbo, razvito profesionalno kulturo in etiko, formalno notranjo organiziranost ter vseživljenjsko izobraževanje. Na podlagi izobraževanja se pridobi »ustrezno, tudi abstraktno strokovno znanje, ki je specifično za vojaško profesijo in ga ni v nobeni drugi profesiji. Hkrati ta proces omogoča nastanek ustrezne profesionalne kulture in etike, ki oblikujeta značaj posameznega člana profesije.«

$\mathrm{Ob}$ tem, ko sicer ni enotnega 'evropskega' modela temeljnega šolanja častnikov, pa je vseeno smiselno v Sloveniji uveljavljen model šolanja predstaviti tudi z vidika prakse v evropskih državah. Tudi v Sloveniji je, tako kot drugje v Evropi, za vstop v častniško profesijo zahtevana univerzitetna izobrazba, častniki opravijo študij na različnih programih fakultet $\mathrm{v}$ javnem šolstvu, nato pa to izobraževanje dopolnijo s specifičnim vojaškim poklicnim usposabljanjem za rod ali službo. ${ }^{15}$ Ugotovimo lahko, da slovenski model izstopa predvsem glede oblike oziroma organiziranosti,

\footnotetext{
15 V Sloveniji to usposabljanje poteka po zaključku univerzitetnega študija v Šoli za častnike Slovenske vojske. Program traja eno leto in je usmerjen predvsem v vojaške, veščinsko naravnane vsebine.
} 
saj pri nas nimamo vojaške univerzitetne izobraževalne institucije. Glede na to, da v evropskih državah častniki na vojaških izobraževalnih institucijah pridobivajo univerzitetno izobrazbo na zelo različnih (tehniških in družboslovnih) programih, študij pa se približuje sicer veljavnim standardom v javnem šolstvu, lahko trdimo, da študij na javnih fakultetah v Sloveniji opravlja enako funkcijo kot šolanje na vojaških akademijah oziroma fakultetah v evropskih državah. Razlika je torej predvsem v institucijah, ki izvajajo izobraževanje, manj pa v vsebinah.

V Sloveniji smo se $\mathrm{v}$ zadnjih petindvajsetih letih bolj ukvarjali z razmišljanjem o oblikah temeljnega šolanja častnikov kot z njegovo vsebino. ${ }^{16}$ Ena temeljnih dilem pri tem je, ali ustanoviti vojaško univerzitetno izobraževalno institucijo ${ }^{17}$ ali izobraževati v javnih univerzitetnih ustanovah. Po pregledu izobraževanja častnikov v državah EU lahko ugotovimo, da uveljavljeni slovenski model univerzitetnega izobraževanja častnikov vsebinsko bistveno ne odstopa od uveljavljene prakse v teh državah. Skoraj povsod je namreč mogoče zaslediti odmik od koncepta klasičnih vojaških akademij in vse več podobnosti izobraževanja častnikov s programi v javnem izobraževanju. V Sloveniji zelo verjetno drugačna rešitev od zdaj uveljavljene niti z organizacijskega niti s stroškovnega vidika ne bi bila smotrna. $\mathrm{Ob}$ upoštevanju potreb po zelo različnih programih univerzitetnega šolanja častnikov in nizki letni potrebi po novih častnikih ${ }^{18}$ se postavlja vprašanje smotrnosti institucije, ki bi izvajala študij le za vojaške potrebe. Ne nazadnje je treba upoštevati obstoj pedagoškega in znanstvenoraziskovalnega potenciala, ki je v javnih univerzitetnih institucijah, vojaška institucija pa bi morala tak kader šele pridobiti.

Pri razpravi o šolanju častnikov pri nas se je mogoče opreti tudi na konceptualni model ločevanja med univerzitetnim izobraževanjem in poklicnim usposabljanjem, ki je uporabljen v analizi načinov šolanja častnikov v članicah EU. Na tem področju bo treba v prihodnje poiskati odgovore na več vprašanj. Najprej lahko ugotovimo, da pri šolanju častnikov univerzitetnemu izobraževanju ne namenjamo ustrezne pozornosti, čeprav je pomembna podlaga njihovega šolanja. Ob tem, ko interes za častniški poklic med mladimi, ki končajo univerzitetno izobraževanje, še omogoča pokrivanje potreb SV v količinskem smislu, pa glede strukture naletimo na težave. Kot vidimo v tujini, vojske v svojih izobraževalnih institucijah izvajajo različne programe, ki jih potrebujejo. Pri nas vstop v častniške vrste opredeljujeta najprej interes posameznikov in trg delovne sile, ${ }^{19} \mathrm{v}$ nadaljevanju pa selekcijski izbor za šolo za častnike, pri katerem se preverjajo psihofizične sposobnosti in voditeljski potencial posameznika. Zato smer izobrazbe ni med najpomembnejšimi kriteriji,

\footnotetext{
${ }^{16}$ O tej problematiki smo obširneje pisali v eni izmed prejšnjih številk revije Sodobni vojaški izzivi. Glej Zabukovec in Vegič, 2014.

${ }_{17}$ Obravnavana je bila možnost ustanovitve »vojaške fakultete«. Podrobneje o tem v: Zabukovec in Vegič, 2014, str. 66 .

18 Po ocenah Generalštaba SV bi ob ohranjanju sedanjega obsega vojske potrebovali največ do 35 novih častnikov na leto.

${ }^{19}$ Diplomanti študijskih smeri, ki imajo boljše zaposlitve in karierne možnosti na trgu delovne sile, pogosto niso zainteresirani za zaposlitev $v$ vojski oziroma za častniški poklic.
} 
posledično pa struktura častnikov glede na smer univerzitetne izobrazbe ni ustrezna potrebam. Najbolj zaskrbljujoče je pomanjkanje kandidatov iz tehniških študijskih programov. Glede na pregled potreb, ki ga je pripravil Generalštab SV za obdobje od 2016 do 2021, bi med novimi častniki potrebovali 50 odstotkov takih s tehnično smerjo izobrazbe. Podatki kažejo, da v zadnjih letih SV dosega le približno polovico teh potreb, delež pa se še zmanjšuje. ${ }^{20}$

Med izzive, s katerimi se bo treba spopasti v prihodnje, spada tudi prilagajanje programov na univerzah potrebam vojske. To zdaj, ko se posameznik za častniško profesijo odloča šele po študiju, ni mogoče. Univerzitetno izobraževanje je popolnoma ločeno od potreb vojaške organizacije. Vprašanje je tudi, koliko in kako poleg vsebin, ki so »matične« za posamezne izobraževalne programe, bodočim častnikom že med študijem zagotoviti temeljno znanje s področja vojaške stroke. Danes v času študija bodoči častniki ne dobijo znanja o vojaških zadevah, prvi stik z vojaško stroko in vojaško organizacijo vzpostavijo šele po končanem univerzitetnem študiju. Zato med študijem tudi ni možnosti za »vojaško socializacijo《 in razvoj voditeljskih sposobnosti, kar je mogoče tam, kjer univerzitetno izobraževanje izvajajo na vojaških institucijah. Vse to kaže, da je SV na področju univerzitetnega izobraževanja predvsem v vlogi »uporabnika«, ne pa »preskrbovalca« kadrov.

Za napredek v šolanju častnikov pri nas bo pomembno povečanje sodelovanja in doseganje sinergije med javnimi izobraževalnimi institucijami in vojsko ter skrb za vojaško stroko. Slovenska vojska bo morala natančno opredeliti potrebe in izraziti pričakovanja glede izobraževalnih vsebin, ki jih pričakuje od drugih izobraževalnih institucij. ${ }^{21} \mathrm{~V}$ tesnejšem sodelovanju z institucijami javnega izobraževalnega sistema bi bilo treba predvsem iskati odgovor, kako zagotoviti zelo različne profile kadrov, ki so za vojsko nujni. Usmeriti se je smiselno predvsem na pridobivanje znanj, ki so častnikom potrebna, pa jih znotraj vojaške organizacije ni smotrno razvijati. Pri tem morata biti vodili uporabnost in izbor kakovostnih študijskih programov. ${ }^{22}$ Skrb za razvoj vojaške stroke mora ostati predvsem v pristojnosti SV. Tako vojaška znanost kot veščina se razvijata $v$ tesnem stiku s prakso, zato njunega razvoja ni mogoče prepustiti javnim izobraževalnim ustanovam. Predvsem morajo v domeni SV ostati vsebine poklicnega usposabljanja častnikov, torej tiste, ki so ključne za opravljanje konkretnega dela.

V takšni »delitvi dela« med javnimi izobraževalnimi ustanovami in SV je mogoče rešiti tudi vprašanje, koliko je v izobraževanju častnikov treba upoštevati univerzitetna merila. V Sloveniji smo se v preteklosti srečevali predvsem z dilemo

${ }^{20}$ Leta 2012 je bilo v generaciji novo izšolanih častnikov še 42 odstotkov takih s tehnično izobrazbo, leta 2014 je takih 24 odstotkov, leta 2016 pa 26 odstotkov. Med tistimi, ki bodo šolanje začeli leta 2017, pa le 18 odstotkov. V preostalem deležu šolajočih se častnikov je največ diplomantov varstvoslovja, sledijo diplomanti obramboslovja, logistike in drugih družboslovnih ter poslovnih in upravnih ved.

${ }^{21}$ Zavedati se je treba, da samo to ne bo dovolj, temveč bo treba izvajati tudi ustrezno kadrovsko politiko, ki bo zagotovila zadosten interes za študij na programih, ki so za vojsko pomembni.

${ }^{22} Z$ naraščanjem števila visokošolskih izobraževalnih institucij v Sloveniji v zadnjih dveh desetletjih je prišlo tudi do povečevanja razlik glede kakovosti izvajanja študijskih programov. 
glede potrebe po učiteljih, habilitiranih po visokošolskih merilih. ${ }^{23}$ To je potrebno pri tistih vsebinah, ki so podlaga za pridobitev diplome, torej v programih v javnih izobraževalnih ustanovah. Ni pa smiselno pri takih kriterijih vztrajati pri poklicnem usposabljanju častnikov, torej pri programu, ki se izvaja v Šoli za častnike.

Sklep Primerjavo med slovenskim modelom in evropsko prakso temeljnega šolanja častnikov lahko sklenemo s priporočilom, da je smiselno ločevati med vsebinskimi in organizacijskimi vidiki tega procesa. Vsebino določajo predvsem potrebe častniške profesije, ki so na evropski ravni precej podobne, vse večji obseg delovanja vojsk v večnacionalnih okvirjih pa bo določal nadaljnje vsebinsko približevanje. Organizacijske oblike šolanja so zelo različne in odvisne od potreb, zmožnosti, tradicije in drugih dejavnikov, značilnih za vsako državo. Prihodnji razvoj šolanja častnikov pri nas bo moral slediti praksi tujih držav predvsem na vsebinskem področju, način organiziranja pa je smiselno prilagoditi lastnim potrebam in zmožnostim.

Kljub vsebinskim in predvsem organizacijskim razlikam $\mathrm{v}$ temeljnem šolanju častnikov, ki jih pokaže primerjava na evropski ravni, je povsod temeljno vodilo prilagajanje šolanja potrebam vojaške profesije, zato je treba v ospredje razmislekov o šolanju častnikov postaviti razumevanje vojaške profesije. Znanje vojaškega profesionalca pri nas je sinteza znanja, ki ga posameznik pridobi v javnih izobraževalnih ustanovah, in znanja, ki ga pridobi na šolanju znotraj SV. Razvoj in posredovanje vojaškostrokovnega znanja, ki pomembno določa kakovost vojaških profesionalcev, je v domeni SV. Njene vojaške izobraževalne institucije niso odgovorne samo za veščinsko usposabljanje, temveč tudi za razvoj vojaške znanosti. Spremembe na področju razumevanja vojaškega izobraževanja kažejo, da je treba že na nižjih ravneh šolanja častnike opremiti s širšim in bolj abstraktnim teoretičnim znanjem. Temeljnega šolanja častnikov v SV torej ne smemo razumeti le kot pripravo na opravljanje prve častniške dolžnosti, temveč kot izobraževalni proces, ki bo omogočal profesionalni razvoj tudi v nadaljnji karieri častnika in zagotovil podlage za nadaljevalno karierno izobraževanje.

\section{Literatura}

1. Doktrina vojaškega izobraževanja in usposabljanja, 2013. Slovenska vojska.

2. Education and Training Directive - Bi-SC 75-2, 2013. NATO.

3. Foot, P., 2006. Military Education and the Transformation of the Canadian Forces. Canadian Military Journal. www.journal.forces.gc.ca/vo7/no1/doc/transfor-01-eng.pdf (6. 7. 2016)

4. International Military and Defence Encyclopedia, 1993. Washington, Brassey's.

\footnotetext{
${ }^{23}$ Na sploh so merila glede izvajalcev vojaškega izobraževanja in usposabljanja (VIU) precej ohlapno opredeljena. Ločevanja med univerzitetnim izobraževanjem in poklicnim usposabljanjem (kot smo ga predstavili v prispevku) slovenski normativni akti, ki obravnavajo VIU, ne poznajo. V 20. členu Zakona o službi v SV je zapisano, da »organizacija in izvajanje vojaškega izobraževanja poteka v skladu z Zakonom o obrambi in predpisi, ki urejajo srednje poklicno in strokovno izobraževanje ter višje strokovno in visokošolsko izobraževanje ter podiplomski študij. «Pri tem ni jasno opredeljeno, kaj je vojaško izobraževanje niti v katerih primerih bi bilo treba te predpise upoštevati. Tako zapisane zahteve omogočajo različne interpretacije.
} 
5. Johnson-Freese, J., 2013. Prerequisites to Transformative Joint Professional Military Education. VWells, L., Hailes T., C., Davies M., C., (ur.) Changing Mindsets to Transform Security: Leader Development for an Unpredictable and Complex World. Washington, National Defense University.

6. Kotnik, I., 2012. Profesionalizacija slovenske vojske-cilj ali pot. Sodobni vojaški izzivi, $14 / 1$.

7. Kramar, M., 1996. Vojaška didaktika. Ljubljana, Ministrstvo za obrambo.

8. McCausland J. D., Martin, G. F., 2001. Transforming Strategic Leader Education for the 21st-Century Army. Parameters, Autumn 2001.

9. Munnik, T,. 2012. Teaching War. V Lindley-French, J., Boyer, Y. (eds.). The Oxford Handbook of War.

10. Paile, S., 2011. Compendium of the European Military Officers Basic Education. orbi.ulg. ac.be/bitstream/2268/100625/1/Compendium.pdf (21. 9. 2016).

11. Potočnik, V., 2012. Vojaška profesija in profesionalni častnik včeraj, danes in jutri. Sodobni vojaški izzivi, 14/1.

12. U.S. Profesional Military Education Policy, 2015.

13. https://archive.org/stream/Officer-Professional-Military-Education-Policy-29-May-2015/ Officer\%20Professional\%20Military\%20Education\%20Policy,\%2029\%20May\%20 2015_djvu.txt

14. Vojaška doktrina, 2006. Poveljstvo za doktrino, razvoj, izobraževanje in usposabljanje. Ljubljana.

15. Zabukovec, S., Vegič, V., 2014. Izobraževanje častnikov-od razprav o organiziranosti k razmisleku o vsebinah. Sodobni vojaški izzivi, 16/2.

16. Žabkar A., Svete, U., 2008. Šolanje vojaških profesionalcev med tradicionalnimi izhodišči in (post)modernimi izzivi. Bilten slovenske vojske, 10/1. 


\section{VOJAŠKO IZOBRAŽEVANJE V SLOVENSKI VOJSKI - IZZIVI PRIHODNOSTI}

\section{MILITARY EDUCATION IN THE SLOVENIAN ARMED FORCES - FUTURE CHALLENGES}

Povzetek V članku sta prikazana na arhivskih virih in literaturi z analizo SWOT temelječa vojaško izobraževanje v Slovenski vojski in možnost njegovega nadaljnjega razvoja. Opisano je povezovanje vojaškega izobraževalnega in znanstvenoraziskovalnega sistema v Slovenski vojski s sistemom izobraževanja in znanstvenoraziskovalnega dela v Republiki Sloveniji ter v mednarodnem okolju tako, da je prikazan razvoj vojaškega izobraževanja v oboroženih silah Republike Slovenije, ki se je z njenim nastankom leta 1991 na novo oblikovalo, in to od osnovnega usposabljanja vojakov nabornikov do najvišjih oblik vojaškega izobraževanja in znanstvenoraziskovalnega dela na področju vojaških ved. V nadaljevanju so predstavljene pomanjkljivosti sedanjega vojaškega izobraževanja in njegov mogoč razvoj, ki bi potekal, tako kot v drugih zavezniških državah, v smeri vključevanja v bolonjski izobraževalni in znanstvenoraziskovalni sistem.

Ključne Republika Slovenija, Slovenska vojska, vojaško izobraževanje, bolonjski besede izobraževalni sistem, analiza SWOT.

Abstract The article depicts the military education model of the Slovenian Armed Forces and the possibility of its further development, which are both based on archive resources and SWOT analysis. It describes the integration of the military education and scientific and research system in the Slovenian Armed Forces with the education system and scientific research system in the Republic of Slovenia and internationally. It first describes the development of military education in the armed forces of the Republic of Slovenia, which was formed anew after Slovenia gained independence in 1991. It ranges from the basic conscript training to the most advanced forms of military education and scientific and research efforts in the field of military science. The article continues by presenting the shortfalls of the current military education system and possible ways of its development, which can be directed in a similar way 
as in other allied nations, namely by incorporating it into the Bologna education system and scientific research system.

Key words Republic of Slovenia, Slovenian Armed Forces, military education, Bologna education system, SWOT analysis.

\section{Uvod "Znanost lahko koristi pri vodenju oborožitve.॥}

Misel je razvil podpolkovnik baron Jurij Vega v prošnji cesarju Jožefu II. za dovoljenje, da bi smel kot učitelj matematike na bombardski šoli prostovoljno sodelovati v vojni z osmanskimi Turki, ki se je začela leta 1788. V bitki pri Beogradu je Jurij Vega ukazal močnejše nabijanje možnarjev, ustrezno je popravil nagib cevi in izboljšal tesnjenje med cevjo ter izstrelkom, in sicer tako, da je uporabil koščke lesa. Možnarji so po opravljenih spremembah učinkoviteje zadevali cilje. Pruski minister Hertzberg je ugotovil: »da je Vegovo odkritje smrtonosen strel za Turke« (Pisanski, 2006).

V preteklosti so številni avtorji, ki so bili tako ali drugače del procesa vojaškega izobraževanja Slovenske vojske, vsak iz svojega, pa vendar skupnega, imenovalca predlagali izpopolnitev sedanjega sistema vojaškega izobraževanja v Slovenski vojski: Liliana Brožič v članku Izobraževanje v oboroženih silah, Igor Kotnik v članku Raznolikost izobraževanja vojaških častnikov, Mojca Pešec in Uroš Krek v članku Can the process of professional military education create military strategists, Dušan Toš v članku Slovensko vojaško šolstvo, zamujena priložnost in izzivi v prihodnosti ter Vinko Vegič in Stojan Zabukovec v članku Izobraževanje častnikov: od razprav o organiziranosti $k$ razmisleku o vsebinah. Pri tem ne smemo prezreti tudi strokovnjakov zunaj Slovenske vojske, ki so tej problematiki posvetili veliko pozornosti. Izmed teh bi rad izpostavil predvsem članek Antona Žabkarja in Uroša Sveteta o šolanju vojaških profesionalcev.

Kot je zapisano v aktualni Doktrini vojaškega izobraževanja in usposabljanja Slovenske vojske: »Vojska potrebuje izobražene in dobro izurjene, disciplinirane, osebnostno zrele ter visoko etične pripadnike. Potrebuje vojake, ki jim znanje in veščine omogočajo kritično presojati in se aktivno odzivati na spremembe $v$ kompleksnih razmerah. Potrebuje voditelje z moralno integriteto, ki imajo znanje in sposobnosti za delovanje na različnih ravneh doma in v mednarodnih vojaških strukturah ter so sposobni delovati v različnih okoljih in sodelovati z nevojaškimi akterji. Potrebuje vojake, ki so sposobni vzpostaviti ustrezno razmerje med zahtevami vojaške hierarhije in discipline po eni ter potrebo po ustvarjalnosti, iniciativnosti in svobodi kritične misli ter izmenjavi strokovnih mnenj po drugi strani. Potrebuje vojake, ki sledijo načelom in pravilom vojaške doktrine naše vojske in zavezništva, vojake z moralnimi in etičnimi značilnostmi, ki jim narekujejo zavzeto in predano opravljanje poklica, so lojalni, domoljubni in tovariški. Njihovo vodilo pri opravljanju nalog je med drugim tudi kodeks vojaške etike.« (Doktrina VIU, 2013) Iz tega izhaja, da je postal prehod vojaškega izobraževanja, ki se v Slovenski vojski 
zdaj izvaja kot interno, na raven vsebinskega in organizacijskega povezovanja in integracije $\mathrm{z}$ višješolskim ter visokošolskim bolonjskim izobraževalnim sistemom na nacionalni in mednarodni (vojaški) ravni nuja nadaljnjega razvoja in posledično preživetja organizacije.

V članku razčlenjujemo z analizo SWOT (Vaupotič, 2012) vojaško izobraževanje v Slovenski vojski in možnost njegovega nadaljnjega razvoja oziroma povezovanje vojaškega izobraževalnega in znanstvenoraziskovalnega sistema v Slovenski vojski s sistemom izobraževanja in znanstvenoraziskovalnega dela v Republiki Sloveniji ter v mednarodnem okolju.

\section{PREDNOSTI SISTEMA VOJAŠKEGA IZOBRAŽEVANJA V SLOVENSKI VOJSKI}

\subsection{SV ima oblikovan interni sistem vojaškega izobraževanja in usposabljanja, ki deluje večinoma nespremenjen od leta 1992}

V nasprotju z operativnim delom Teritorialne obrambe (TO), ki so ga po obrambni vojni »zgolj« preoblikovali iz vojnega v mirnodobno stanje, je bilo treba postaviti sistem izobraževanja in usposabljanja starešin TO popolnoma na novo. Že 16. decembra 1991 so začeli delati častniki in podčastniki, ki so pripravili vse nujno za začetek izobraževanja in usposabljanja slušateljev na Šoli za podčastnike (ŠPČ). Prva generacija 58 slušateljev je začela šolanje 6. januarja 1992 in ga končala 16. maja istega leta. Šola je bila temeljna za poznejše oblikovanje Izobraževalnega centra Ministrstva za obrambo Republike Slovenije (IC MORS) kot organizacijske enote v sestavi Ministrstva za obrambo Republike Slovenije oziroma Centra vojaških šol (CVŠ), ki je leta 1999 postal sestavni del Slovenske vojske in v katerem so, zraven ŠPČ, kot prve delovale Šola za častnike (ŠČ), Šola za častnike (rezervnih) vojnih enot ( (̌́ ̌ VE) in Poveljniško-štabna šola (PŠŠ), z njimi pa tudi temelj organiziranega izobraževanja in usposabljanja starešin TO (Kladnik, 2007).

Z namenom povezave vojaškega izobraževanja in usposabljanja z znanstvenoraziskovalnim delom na področju vojaške znanosti in doktrin ter posledično pridobitvijo možnosti neposrednega uvajanja novega vojaškega znanja skozi šolski sistem v prakso sta se leta 2004 s Poveljstvom za doktrino, razvoj, izobraževanje in usposabljanje (PDRIU) povezala Center vojaških šol in Delovna skupina za doktrino in razvoj Generalštaba Slovenske vojske. Tako se je vzpostavil sistem vojaškega izobraževanja in usposabljanja, ki je obsegal temeljno, osnovno in dopolnilno vojaško izobraževanje in usposabljanje. Zagotavljal je sistematično in načrtno pripravo za začetne dolžnosti v vojaškem poklicu, nenehno izboljševanje vojaškostrokovne usposobljenosti, usposabljanje za tipične dolžnosti $\mathrm{v}$ posameznem vojaškem poklicu ter usposabljanje vojaških enot za učinkovito izvajanje nalog. Sistem je omogočal redne oblike izobraževanja in usposabljanja iz dela ter izobraževanje in usposabljanje ob delu ter na daljavo. Po obsegu, organizaciji in vsebini izobraževanja in usposabljanja je bil prilagojen načrtovani strukturi in nalogam vojske s težiščem 
na praktičnem usposabljanju posameznika in osnovnih taktičnih enot. Zagotavljal je takšno raven vojaške izobrazbe in usposobljenosti, ki je omogočala gibljivost vojaškega kadra znotraj celotnega obrambnega sistema ter prehodnost iz civilnih poklicev v vojaške in obratno. Posebna pozornost pa je bila pri tem usmerjena $\mathrm{v}$ razvoj osnovnih vojaških veščin in ved. Tako je postal PDRIU nosilec vojaškega izobraževanja in usposabljanja ter znanstvenoraziskovalnega dela in tehnološkega razvoja vojske. Pri izvajanju vojaškega izobraževanja in usposabljanja je sodeloval z domačimi in tujimi izobraževalnimi ustanovami ter enotami Slovenske vojske. S sodelovanjem civilnih izobraževalnih ustanov so se izvajale predvsem najvišje oblike izobraževanja, kot je podiplomski študij. Z vgradnjo vojaških modulov v programe višjih in visokih šol ter fakultet pa se je uvajalo tudi izobraževanje za pridobitev osnovne izobrazbe, medtem ko se je dopolnilno vojaško izobraževanje in usposabljanje izvajalo tudi v tujini (Kladnik, 2007).

Z reorganizacijo Slovenske vojske se je maja 2013 ustanovil Center vojaških šol (CVŠ), katerega poslanstvo so ustvarjanje in pridobivanje vojaškega znanja ter razvoj vojaških znanstvenih disciplin, vojaških ved in z njimi povezanih ved, na katerih temeljijo njihovi študijski programi $\mathrm{z}$ namenom izvajanja poslanstva Slovenske vojske. Kakovost delovanja CVŠ zagotavljajo vrednote, iz katerih izhajajo: odličnost študijskih programov in programov usposabljanja, harmoničnost kolektiva, strokovna rast ter dobro počutje slušateljev, odprt odnos med predavatelji, tutorji in slušatelji ter učinkovito vključevanje $\mathrm{v}$ mednarodno izobraževalno in znanstveno dejavnost ter se zato povezovati s sorodnimi ustanovami doma in v svetu. Naloge CVŠ, ki izhajajo iz poslanstva CVŠ, so: izvedba vojaških izobraževalnih programov in programov vojaškega usposabljanja, doseganje kakovostnih meril, $h$ katerim zavezuje zakonodaja, ter meril, ki jih predpisujeta in priporočata Nato in EU, raziskovanje in razvoj na področju vojaških ved ter z njimi povezanimi vedami, skrb za vojaško kulturno dediščino, priprava vojaškostrokovne literature, učbenikov in študijskega gradiva, razvoj učnih pripomočkov in učne infrastrukture, programiranje in razvoj programov, načrtovanje izvedbe izobraževanja in usposabljanja, evalvacija izobraževanja in usposabljanja, elektronsko izobraževanje, sodelovanje z izobraževalnimi in raziskovalnimi ustanovami, sodelovanje in izmenjava znanja z drugimi ustanovami ter knjižnično-informacijska in založniška dejavnost (SOP CVŠ, 2015).

\subsection{SV ima habilitirane in druge strokovnjake, ki bi jih ob ustreznem kadrovskem izboru in poklicni poti usmerili v razvoj vojaških ved}

Kot je zapisano v Doktrini VIU (2013), se v SV kot izvajalci vojaškega izobraževanja in usposabljanja vključujejo različni strokovnjaki. Za kader, ki opravlja pedagoško delo, morajo biti izbrani posamezniki, ki so prepoznani kot najboljši poznavalci vojaške in obrambne stroke, imeti pa morajo tudi možnost nenehnega dopolnjevanja znanja. Zato je treba ohraniti kakovostni standard pedagoško-andragoškega znanja izvajalcev izobraževanja in vztrajati z uveljavitvijo zahteve po certifikatu o pedagoški usposobljenosti, ki ga mora imeti vsak pripadnik, ki predava ali uri vojake v ustanovah VIU. V SV sta izobraževanje in usposabljanje zaupana izvajalcem, ki 
so na formacijskih mestih učiteljev, in tistim, ki v proces vstopajo, kadar je treba (častniki in podčastniki, vojaški uslužbenci ter zunanji sodelavci), morajo pa izpolnjevati pogoje za opravljanje teh nalog.

\subsection{SV ima opremo in infrastrukturo za izvedbo izobraževalnega in znanstvenoraziskovalnega dela}

Prilagajanje pogojev usposabljanja realnim razmeram uporabe in delovanja enot ter poveljstev je bilo izhodišče za vlaganje v objekte, opremo in sredstva za usposabljanje. Tako so bili v sistemu izobraževanja in usposabljanja zagotovljeni simulatorji, naprave, pripomočki in simulacije za virtualno usposabljanje posameznikov, posadk in enot, kot so simulatorji in trenažerji za oborožitvene sisteme, bližinski boj, streljanje itn. Prav tako pa je s simulatorji in simulacijskimi programi podprto usposabljanje poveljstev in enot od voda navzgor, kot so bataljonski, brigadni in divizijski simulacijski program, z možnostjo povezave v kombinirane in združene mednarodne vaje. $Z$ oblikovanjem in opremljanjem Centra za bojno usposabljanje v Postojni ter nabavo laserskih tehničnih sistemov in streliva za urjenje so se vzpostavili tudi nujne zmogljivosti in pogoji za usposabljanje enot do ravni bataljonske bojne skupine. Ustrezne terenske razmere za izvajanje izobraževanja in usposabljanja pa se vzpostavljajo tudi s posodabljanjem strelišč in vadišč Mlake in Apače. Ustrezna infrastruktura za taktično urjenje, strelsko kondiciranje in šport pa se zagotavljajo tudi znotraj posameznih vojašnic Slovenske vojske. Sodobne razmere za namestitev in delovanje vojaškega izobraževalnega sistema pa so bile zagotovljene $\mathrm{z}$ obnovo in revitalizacijo kompleksa Vojašnice generala Maistra v Mariboru oziroma objekta Kadetnica (Kadetnica, 2011).

\subsection{SV ima Knjižnično-informacijski in založniški center}

Knjižnično-informacijsko in založniški center MO RS je specialna knjižnica $\mathrm{v}$ sistemu javne uprave in osrednja knjižnica MO RS. Organizacijsko je umeščen k CVŠ, s svojim delovanjem pa zagotavlja knjižnično, dokumentacijsko, informacijsko in založniško podporo vsem pripadnikom SV in uslužbencem MO RS ter hiter in neoviran dostop do virov, ki jih potrebujejo pri delu in izobraževanju. Kot osrednja knjižnica ministrstva uresničuje svoje poslanstvo z nalogami vodenja in knjižnične podpore vsem OE v sistemu MO ter Slovenske vojske. Za vse OE izvaja postopke nakupa, strokovne obdelave in distribucije knjižnično-informacijskih virov. Poleg tega izvaja zanje matično službo. Matična služba zagotavlja in daje strokovno podporo knjižnično-informacijskim točkam (KIT) v vseh odsekih njihovega delovanja. Informacijska služba posreduje uporabnikom podatke iz slovenskega knjižnično-informacijskega sistema COBISS/OPAC in mednarodnih podatkovnih zbirk, zagotavlja prost dostop do strokovnih časopisov ter neknjižnega gradiva. Kot aktivni član sodeluje v Nacionalnem vzajemnem bibliografskem sitemu Cobiss, kar pomeni, da prevzema obveznosti in naloge, ki izhajajo iz tega. Tako sodeluje v procesih vzajemne katalogizacije, knjižnično gradivo iz zaloge Knjižničnoinformacijskega centra MO RS pa je javno dostopno v elektronskem katalogu Cobiss, do katerega imajo prosti dostop uporabniki, ki jih to zanima. Prav tako spada 
med njegove naloge vodenje bibliografije strokovnih delavcev in raziskovalcev tako Ministrstva za obrambo RS kot pripadnikov Slovenske vojske. Do Digitalne knjižnice MO RS lahko dostopajo vsi zaposleni z MO, ne glede na svojo fizično lokacijo ali specifiko delovnega mesta, ker zagotavlja enake možnosti dostopa do informacij vsem pripadnikom Slovenske vojske. To je tudi zelo pomembno zaradi razpršenosti rednih in rezervnih enot Slovenske vojske in različnih kriznih žarišč, na katerih delujejo pripadniki. Digitalna knjižnica omogoča dostop do publikacij, ki jih izdaja založniška služba ministrstva, zaključnih nalog vojaških izobraževalnih programov in zaključnih nalog zaposlenih na ministrstvu, ki imajo sklenjeno pogodbo o izobraževanju v civilnih izobraževalnih ustanovah, zaključnih poročil CRP-MIR, raziskovalnih poročil TP-MIR in znanstvenih časopisov MO. Zaposlenim na MO RS omogoča tudi dostop do plačljivih virov IHS Jane's, Military Periscope, Stratfor, ProQuest in EBSCO (SOP CVŠ, 2015).

\subsection{SV ima znanstveno-strokovno publikacijo}

Slovenija ima samo eno znanstveno-strokovno publikacijo, ki je namenjena vojaškoobrambnim vsebinam. Izdaja jo Generalštab Slovenske vojske. Jeseni 1999 je izšla prva številka publikacije Bilten Slovenske vojske, ki jo je izdal Generalštab Slovenske vojske. Njen namen je bil, da pripadniki Slovenske vojske in Ministrstva za obrambo, ki so se izobraževali in usposabljali doma in v tujini, svoje izkušnje zapišejo ter jih tako delijo z drugimi. Leta 2011 se je Bilten preimenoval v Sodobne vojaške izzive ali angleško v Contemporary Military Challenges, kar odraža bistvo publikacije Slovenske vojske in to je vojaštvo (Military). Iz prvih pridevnika in samostalnika je razvidno, da gre za aktualno vojaško tematiko, in ne za zgodovinske vsebine. Teh imamo v Republiki Sloveniji precej, zato je aktualnost vsebin, ki jih izdaja Slovenska vojska, tista pomembna prepoznavna lastnost, ki jo sporoča novo ime. Slovenska vojska ima zagotovo največ priložnosti biti v stiku z aktualnimi dogodki in trendi na obrambno-varnostnem področju. Če dobro prakso združimo z aktualno teorijo in omogočimo nove ugotovitve, rešitve ali predloge, smo zagotovo na dobri poti v prihodnost. S pisanjem o aktualnih obrambnovojaških vsebinah delimo znanje in izkušnje z drugimi domačimi in tujimi avtorji ter bralci. Na prvem mestu po objavljanju člankov v Sodobnih vojaških izzivih so tako zaposleni v Slovenski vojski, na drugem različni slovenski avtorji, sledijo avtorji iz tujine. Publikacija je uvrščena v bibliografsko zbirko podatkov COBISS.SI in PAIS International ter je $\mathrm{v}$ postopku za vključitev v bazo Scopus (Brožič, 2014).

\subsection{SV ima v omejenem obsegu na razpolago ustrezne finance za izvedbo vojaškega izobraževanja}

»Padanje deleža obrambnih izdatkov v BDP se bo leta 2017 ustavilo pri 0,91 odstotka. Od leta 2018 do 2020 se bo delež obrambnih izdatkov v BDP postopno povečeval do 1,03 odstotka BDP. V povprečju se bodo obrambni izdatki od leta 2017 med letom povečali za okoli 35 milijonov evrov in bodo leta 2020 dosegli 478 milijonov evrov, kar je 104 milijone evrov več kot leta 2017. Stroški za investicije $v$ modernizacijo obrambnih zmogljivosti bodo v obdobju 2016-2018 še vedno 
neuravnoteženo in nezadostno rastli ter bodo leta 2018 dosegli 4 odstotke v strukturi obrambnih izdatkov oziroma petino ciljnega deleža (20 odstotkov). V letih 2019 in 2020 se bo ta delež povečal na 9 oziroma 15 odstotkov. Stroški za osebje bodo glede na leto 2016, ko predstavljajo v strukturi obrambnih izdatkov več kot 80 odstotkov, postopno padali in bodo leta 2020 predstavljali 67 odstotkov. Leta 2020 bo razmerje med stroški za osebje, operativnimi stroški in stroški investicij znašalo $67: 18: 15$, kar predstavlja premik v smeri ciljnega razmerja 50:30:20. Stroški za osebje bodo predstavljali največji strošek v strukturi obrambnih izdatkov«(SOPR, 2015).

Slika 1:

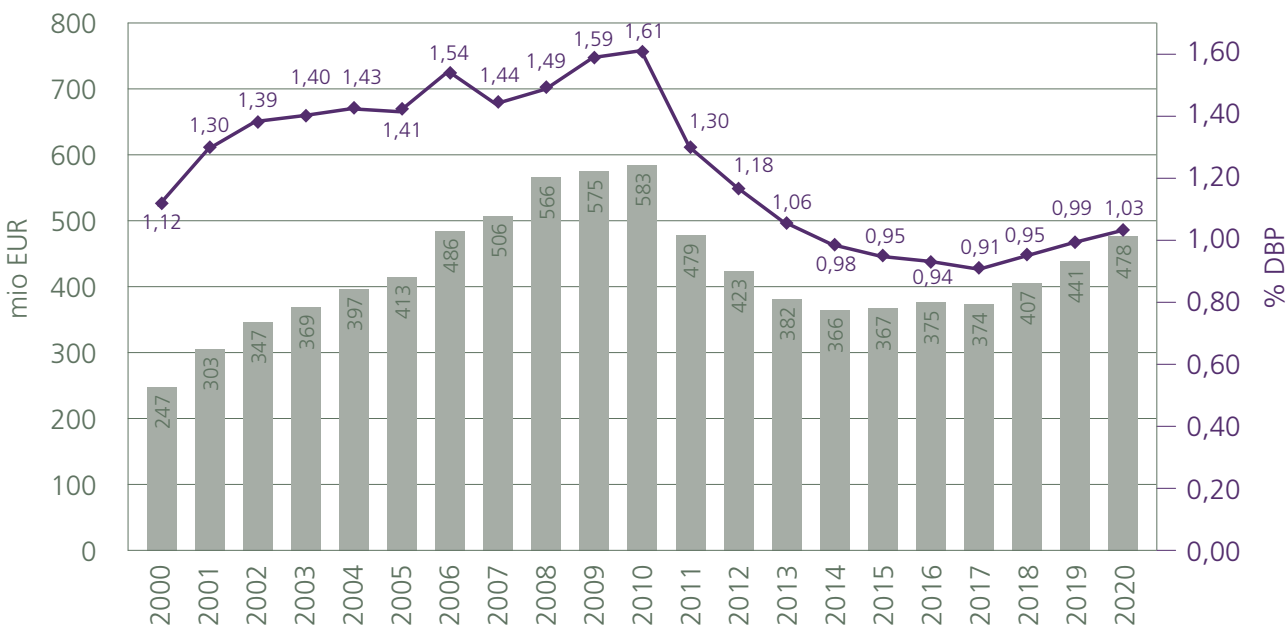

$\mathrm{Ol}($ mio EUR $) \rightarrow \mathrm{OI}(\% \mathrm{BDP})$

\subsection{SV ima dostop in možnost povezovanja ter izmenjave učiteljev in študentov ter vključevanja v znanstvenoraziskovalne projekte v Natu in EU}

Za zagotovitev in izboljšanje kakovosti vojaškega izobraževanja je bila v okviru Nata sprejeta odločitev, da se izvede uvedba mednarodnih standardov na področju vojaškega izobraževanja v okviru ustanov, ki za Natove potrebe izvajajo izobraževanje in usposabljanje (vključene so tudi partnerske države). Uvedba standardov obsega uvajanje treh pomembnih sestavin: izobraževalni cilji, izobraževalni standardi in proces zagotavljanja kakovosti. V direktivi, ki vsebuje tudi Koncept izobraževalnih standardov in Standarde ter napotila za zagotavljanje kakovosti na področju izobraževanja in usposabljanja, je razložen postopek za akreditacijo Nata in partnerskih izobraževalnih ustanov. Novi način akreditacije znotraj Nata akreditacija izobraževalnih ustanov (in ne posameznih programov) - se je začel 1. junija 2012. V procesu akreditacije bodo najprej sodelovale ustanove, ki se bodo za to prostovoljno prijavile in že večinoma zagotavljajo pogoje iz minimalnih meril 
za zagotavljanje kakovosti. Postopek bo potekal tako: ustanova najprej izpolni vprašalnik o zagotavljanju kakovosti in ga pošlje v Joint Task Force (JFT), v JFT skrbno proučijo vprašalnik in pripravijo ekipo za obisk v ustanovi, obisk se izvede skladno z Opomnikom za zagotavljanje kakovosti, v JFT pripravijo poročilo, v katerem predlagajo: takojšnjo akreditacijo ustanove, pogojno akreditacijo ( 9 mesecev za odpravo pomanjkljivosti), odloženo akreditacijo (18 mesecev do naslednje evalvacije), poročilo je dostopno ustanovi, ki se ocenjuje, in ACT, akreditacija načeloma velja približno 6 let. Tak proces bodo morale imeti vse ustanove, ki bodo v prihodnosti želele svoje usluge predstavljati na »Natovem trgu IU«, saj bodo lahko vstopile v Natov Training Management System le ustanove, ki zagotavljajo ustrezne kakovost in standarde usposabljanja. Tako želijo v JFT zagotoviti ustrezno visoke standarde na področju IU in ustrezno usposobljeno osebje tako v Natovi poveljniški strukturi kot tudi v operacijah (Natov Education and Training Directive, 2013).

Veliko možnosti za sodelovanje na mednarodnem področju izhaja tudi iz našega članstva $\mathrm{v}$ formalnih in neformalnih združenjih vojaških izobraževalnih ustanov. Tako je na primer CEFME (Konferenca poveljnikov vojaških izobraževalnih ustanov srednje Evrope), priložnost za izmenjevanje izkušenj in predlogov na področju razvoja in povezovanja vojaškega izobraževanja. Sodelovanje med članicami CEFME se izraža tudi $\mathrm{z}$ izmenjavo sodelovanja $\mathrm{v}$ pedagoških in znanstvenoraziskovalnih projektih, tako pri že uveljavljenih kot pri oblikovanju novih. Pri tem je pomembno predvsem sodelovanje v projektu Perspektiva EU 2020 in pri pisanju ter izmenjavi znanstvenih člankov na področju vojaških ved $\mathrm{v}$ skupni reviji CEFME ter $\mathrm{v}$ nacionalnih revijah. CEFME pa organizira tudi vsakoletno konferenco študentov, ki na njej aktivno sodelujejo s svojimi strokovnimi prispevki.

\section{SLABOSTI SISTEMA VOJAŠKEGA IZOBRAŽEVANJA V SLOVENSKI VOJSKI}

\subsection{SV ni nosilec razvoja vojaških ved in vojaškega poklica}

Po določilih Doktrine VIU (2013) so: »Raziskave in razvoj namenjeni napredku vojaškega izobraževanja in usposabljanja. Obsegajo razvoj vojaške stroke, vojaških ved in vojaške strokovne literature, programskooblikovanje VIU, uvajanje standardov, novega znanja in novih oblik izobraževanja v programe VIU, prenašanje izkušenj v proces VIU in načrten razvoj kadra za VIU. Razvoj vojaške stroke in vojaških ved se uresničuje tudi z znanstvenoraziskovalno dejavnostjo. Znanstvenoraziskovalna dejavnost v SV se izvaja skladno z zakonskimi določili, ki urejajo področje v Republiki Sloveniji, in merili za vrednotenje uspeřnosti znanstvenoraziskovalnega dela. Nosilec raziskovalnega področja v SV je institucija, ki je zadolžena za izvajanje temeljne in aplikativne raziskovalne dejavnosti v SV. Med institucijo, ki je nosilka raziskav $v$ SV, je vzpostavljena povezava s centri za učenje iz izkušenj zavezniških držav in Natovim centrom (JALLC) in ostalimi institucijami doma in v tujini, ki se ukvarjajo z znanstvenoraziskovalno dejavnostjo pomembno za delovanje obrambnega sistema RS. Vzpostavljena je informacijska podpora za oblikovanje 
baze znanja, ki je dostopna vsem uporabnikom znotraj SV in interno izbranim uporabnikom.« Z reorganizacijo PDRIU se je leta 2013 preoblikoval in razpustil njegov temeljni del, Center za doktrino in razvoj, ki je podobno kot primerljive ustanove in centri povezoval pedagoško ter znanstvenoraziskovalno delo, tudi sistemsko znanstvenoraziskovalno delo in razvoj na področju vojaških ved in prenos spoznanj s pedagoškim procesom v prakso. Če so procesi na področju pedagoškega področja in izvajanja internega vojaškega izobraževanja in usposabljanja bolj ali manj ustrezno prešli pod CVŠ, pa so procesi s področja znanstvenoraziskovalnega dela kar nekako umanjkali ali pa prešli pod GŠSV.

\subsection{SV nima oblikovane osrednje pedagoške in znanstvenoraziskovalne ustanove}

Poslanstvo CVŠ je, kot smo že zapisali, izvajanje izobraževanja, praktičnega izobraževanja in usposabljanja, urjenja ter poučevanja, pridobivanja vojaškega znanja ter razvoj vojaških znanstvenih disciplin, vojaških ved in z njimi povezanih ved, na katerih temeljijo njihovi študijski programi z namenom izvajanja poslanstva SV. Pri izvajanju aktivnosti se povezuje z javnim izobraževalnim sistemom kot tudi s primerljivimi sistemi znotraj zavezništva, predvsem pa s strukturami zavezniškega poveljstva za transformacijo (SOP CVŠ, 2015). V resnici pa je CVŠ tipično vojaško poveljstvo taktične ravni, ki nima vzpostavljenih temeljnih pedagoško-andragoških in znanstvenoraziskovalnih elementov, na katerih delujejo tradicionalne in sodobne pedagoške in znanstvenoraziskovalne ustanove tako civilnega kot tudi mednarodnega vojaškega izobraževalnega in znanstvenoraziskovalnega področja. $\mathrm{Na}$ primer poklicne poti za učitelje vojaških ved in njihova habilitacija, šolsko študijsko leto, izmenjava učiteljev in študentov v sistemu Erasmus itn.

\subsection{SV nima oblikovanega izobraževalnega in znanstvenoraziskovalnega sistema ter izoblikovanih in razvitih znanstvenih disciplin vojaških ved $z$ ustreznimi nosilci, ki bi se vključevali v (civilno) javno in mednarodno vojaško pedagoško in znanstvenoraziskovalno okolje}

V CVŠ deluje kot organizacijska enota Katedra vojaških ved, katere poslanstvo je izvajanje vojaškega izobraževanja in usposabljanja ter znanstvenoraziskovalnega dela na področju vojaških ved. Katedra vojaških ved tako združuje posamezne učitelje, ki so nosilci predmetnih področij in predavatelji posameznih predmetov ter izhajajo iz predmetnih področij na vseh ravneh vojaškega izobraževanja (vojak, podčastnik, častnik, vojaški uslužbenec). Z njimi sodelujejo pri izvedbi in razvoju procesa VIU posamezniki iz drugih enot vojske. Deluje predvsem na pedagoškem področju prenašanja znanja $\mathrm{v}$ internem sistemu vojaškega izobraževanja. $\mathrm{V}$ tem procesu nimajo omogočene pridobitve ustrezne licence, pedagoške habilitacije in usposobitve glede na raven poučevanja. Tako tudi za posamezno predmetno področje niso oblikovani strokovni aktivi, katerih naloga je oblikovati programe izobraževanja tako, da bi jih bilo mogoče skupaj z drugimi predmeti ustrezno akreditirati. Prav tako se z znanstvenoraziskovalnim delom nesistemsko ukvarjajo le posamezniki (SOP CVŠ, 2015). 


\subsection{SV nima javno akreditiranih programov izobraževanja}

Izobraževanje in usposabljanje vojakov, podčastnikov, častnikov in vojaških uslužbencev kot posameznikov poteka na treh različnih stopnjah:

- Temeljna - I. stopnja: obsega temeljno vojaškostrokovno usposabljanje (TVSU) za opravljanje vojaške službe (prostovoljno služenje vojaškega roka in usposabljanje za poklicno delo v stalni sestavi) in temeljno usposabljanje kandidatov za častnike SV. Izvaja se v treh programih, in sicer centralizirano, pod vodstvom in nadzorom Veščinskega centra v Vipavi, ter traja 3,5 meseca. Kandidati za častnike in kandidati za vojaške uslužbence opravijo zadnji mesec TVSU po posebnem programu.

- Osnovna - II. stopnja: zagotavlja znanje in veščine za opravljanje začetnih dolžnosti in obsega osnovno vojaškostrokovno usposabljanje (OVSU) vojakov, osnovno vojaškostrokovno izobraževanje in usposabljanje (OVIU) kandidatov za podčastnike, podčastnikov in častnikov ter osnovno usposabljanje za delo v vojski (OUZD) za nižje in višje vojaške uslužbence.

- Nadaljevalna - III. stopnja: obsega tiste oblike izobraževanja in usposabljanja za vojake, podčastnike in častnike, ki zagotavljajo pridobivanje višje stopnje vojaškostrokovne izobrazbe oziroma znanja in sposobnosti za opravljanje novih oziroma zahtevnejših dolžnosti v SV. Nadaljevalno vojaško usposabljanje za vojake - program za desetnike - obsega pridobivanje veščin, znanja in spretnosti za vsakodnevno opravljanje nalog ter vodenje in poveljevanje skupini, posadki in posamezniku. Nadaljevalna VIU za podčastnike potekajo na treh ravneh (program za štabne in enotovne podčastnike ter podčastnike specialiste, program višjega tečaja za podčastnike, program visokega tečaja za podčastnike) in se izvajajo doma ali v tujini. Nadaljevalna VIU za častnike obsegajo programe štabnega, višjega štabnega ter generalštabnega izobraževanja in usposabljanja za častnike SV. Izvajajo se na Poveljniško-štabni šoli SV, posamezniki pa se udeležujejo primerljivih oblik tudi v tujini (Doktrina, 2013; Predlog, 2014).

Vojaško izobraževanje $\mathrm{v}$ praksi ni usklajeno in opredeljeno kot strokovno izobraževanje, višje strokovno, visokošolsko izobraževanje in podiplomski študij, kot to predvidevajo predpisi javnega izobraževalnega bolonjskega sistema. V obdobju 2012/2013 je bilo prekinjeno sodelovanje oziroma izobraževanje z javnimi izobraževalnimi ustanovami, in sicer za podčastnike na višji stopnji, povezano z višjim štabnim tečajem za podčastnike ter za častnike na 2 . bolonjski stopnji, povezano z višjim štabnim šolanjem. Prav tako niso določene poklicne poti pedagoških in znanstvenoraziskovalnih delavcev. Programi vojaškega izobraževanja so se v posameznih primerih posodobili, vendar še niso javno akreditirani. 


\section{PRILOŽNOSTI ZA RAZVOJ SISTEMA VOJAŠKEGA IZOBRAŽEVANJA V SLOVENSKI VOJSKI}

3.1 SV postane skupaj s partnerskimi izobraževalnimi in znanstvenoraziskovalnimi ustanovami nosilec razvoja vojaških ved in vojaškega poklica

Vojaška znanost je sistem znanja, ved o vseh vrstah dejavnosti oboroženih sil v miru, krizah in vojnah ter o okoliščinah, v katerih se oborožene sile razvijajo in delujejo. Razvoj vojaških ved je temelj razvoja vojske. Zato mora vojska razviti svoj znanstvenoraziskovalni in izobraževalni sistem, ki je hkrati del »civilnega« javnega ter mednarodnega vojaškega znanstvenoraziskovalnega in izobraževalnega sistema (Žabkar, 2003). V vsebinskem in organizacijskem smislu to pomeni, da mora biti CVŠ organiziran in akreditiran kot izobraževalna in znanstvenoraziskovalna organizacija, saj bo lahko le tako enakovreden partner na slovenskem in mednarodnem znanstvenoraziskovalnem ter izobraževalnem področju.

Vojaške vede se delijo na:

- ortodoksne vojaške vede:

- strategija,

- operatika,

- taktika,

- logistika,

- vojaška geografija,

- vojaška zgodovina,

- voditeljstvo in menedžment,

- delovanje rodov oboroženih sil;

- vojaškotehnične vede - oborožitveni sistemi;

- vojaškodružboslovne vede - mednarodno vojno pravo, vojaška sociologija, vojaška psihologija, vojaška andragogika;

- vojaškomedicinske vede;

- vojaško jezikoslovje.

\subsection{SV skupaj s partnerskimi izobraževalnimi in znanstvenoraziskovalnimi} ustanovami s svojimi kadri (SV) vzpostavi osrednjo pedagoško in znanstvenoraziskovalno ustanovo v obliki inštituta vojaških ved

Inštitut vojaških ved izvaja vojaško izobraževanje in znanstvenoraziskovalno delo na področju vojaških ved $v$ sodelovanju z domačimi in tujimi partnerji, in sicer $\mathrm{z}$ vojaškim raziskovanjem, ustvarjanjem in pridobivanjem vojaškega znanja ter razvojem vojaških znanstvenih disciplin, vojaških ved in z njimi povezanih ved, na katerih temeljijo študijski programi inštituta. Izobraževanje je temeljno poslanstvo Slovenske vojske, zato tudi neovirano poteka. Inštitut skrbi za učinkovito vključevanje $\mathrm{v}$ javno in mednarodno vojaško izobraževalno ter znanstvenoraziskovalno dejavnost in se zato povezuje s sorodnimi ustanovami doma in v svetu. 
Učitelji in inštruktorji v zvezi s tem opravljajo naloge:

- predavanja na internih in akreditiranih programih,

- oblikovanje programov - prenova internih in priprava akreditiranih programov na vseh ravneh in smereh,

- oblikovanje elektronskih programov,

- priprava na izvajanje programov v angleškem jeziku,

- znanstvenoraziskovalno delo in priprava na habilitacije,

- priprava in izdaja učnih gradiv,

- strokovno povezovanje doma in v tujini.

Izbor učiteljev in inštruktorjev ter drugih sodelavcev v procesu VIU mora temeljiti na teh merilih:

- vojaškostrokovno znanje in pripravljenost za nenehno izpopolnjevanje predvsem izvajalcev izobraževanja in usposabljanja v ustanovah VIU ter učnih enotah, ki izvajajo temeljno in osnovno vojaško izobraževanje in usposabljanje,

- osebnostne lastnosti, ki so primerne za delo z mladimi in drugimi udeleženci,

- uspešno opravljeno pedagoško-andragoško usposabljanje za izvajalca vojaškega izobraževanja in usposabljanja,

- poznavanje koncepta izobraževanja in usposabljanja v Slovenski vojski,

- sprejemanje vrednostnega sistema in pravil, ki veljajo na področju izobraževanja in usposabljanja v Slovenski vojski.

V IVV se zato oblikujejo oddelki/inštituti, v katerih delujejo poklicni in nepoklicni učitelji, zaposleni $\mathrm{v}$ zavodu, učitelji iz enot SV in MO, učitelji iz civilnih izobraževalnih ustanov in učitelji iz tujih vojaških izobraževalnih ustanov.

\subsection{SV oblikuje skupaj s partnerskimi izobraževalnimi in} znanstvenoraziskovalnimi ustanovami izobraževalni in znanstvenoraziskovalni sistem ter izoblikuje in razvija znanstvene discipline vojaških ved z ustreznimi nosilci, ki so vključeni v (civilno) javno in mednarodno vojaško pedagoško ter znanstvenoraziskovalno okolje

»Ključni dejavniki, brez katerih se ne more oblikovati in organizirati nacionalni vojaški visokošolski sistem, je kakovostni predavateljski kader z doktorati, pridobljenimi na področju strategije in taktike. Ostali predavateljski kadri s področja vojaške tehnike, vojaške zgodovine, vojaške geografije in gostujoči predavatelji iz tujine so komplementarni in tudi pomembni, vendar se brez tistih, ki so doktorirali iz vojaških ved in se prebili od asistentov do profesorjev (na tej poti morajo objavljati številna znanstvena in strokovna dela), ne more ustvariti "gravitacijsko jedro« nacionalne vojaške znanosti niti organizirati podiplomsko študij. Sodobno vojaško visoko šolstvo (temeljno šolanje + specializacija + podiplomski študij) se ne pri nas ne $v$ tujini ne more oblikovati in delovati brez spoštovanja zakonskih aktov in norm, ki veljajo za nacionalne javne visoke šole (bolonjski proces), ter brez 
odpiranja javnosti. V tem sklopu je nujno poudariti, da SV nima podiplomskega študija s področja vojaških znanosti in da bi ga morala imeti, pri čemer bi ga morala povezati $v$ sistem nacionalnih visokih šol ter pri tem najtesneje sodelovati s civilnimi znanstveniki in univerzitetnimi predavatelji (oziroma visokošolskimi institucijami) doma in $v$ tujini. $V$ ta namen mora imeti lastne (ali v tujini najete) kakovostne predavateljske in raziskovalne kadre z javno pridobljenimi visokošolskimi in znanstvenimi nazivi, ki morajo prav tako tesno sodelovati s civilnimi univerzami in raziskovalnimi instituti. Nesporno dejstvo je, da se mora v času sedanje evropske in globalne strateške fluidnosti še veliko bolj kot nekoč upoštevati imperativ, da se, zlasti po sprejemu Slovenije v Evropsko unijo in Nato, vse institucije naše države (vključno z obrambnim sistemom in SV, ki je njegov pomemben sestavni del) ter slovenska družba kot celota pospešeno vključujejo v evropske tranzicijske procese in transatlantske integracije» (Žabkar, 2008).

Nosilci predmetov bi tako postali že habilitirani visokošolski učitelji, ki delajo v obrambnem sistemu, z njimi pa bi sodelovali posamezniki iz vojske z doktoratom znanosti, znanstvenim magisterijem in univerzitetno izobrazbo, in sicer kot visokošolski ali višješolski sodelavci (imenovani v naziv predavatelja, višjega predavatelja ali asistenta). Vsem bi bila omogočena pridobitev znanstvenega naziva. Visokošolski učitelji in sodelavci bi poleg pedagoškega procesa (poučevanje, oblikovanje programov, skript, učbenikov, e-učilnic idr.) opravljali tudi znanstvenoraziskovalno delo s svojega predmetnega področja. Katedra vojaških ved oziroma Inštitut vojaških ved bi skrbel za učinkovito vključevanje v mednarodno vojaško izobraževalno in znanstveno dejavnost ter se zato povezoval s sorodnimi ustanovami doma in v svetu. Zato se znotraj njega oblikujejo katedre/oddelki, v katere bodo vključeni poklicni učitelji, zaposleni v zavodu, učitelji iz enot SV in MO, učitelji iz civilnih izobraževalnih ustanov in učitelji iz tujih vojaških izobraževalnih ustanov. Poslanstvo katedre/inštituta bi torej bilo, da znotraj Slovenske vojske in ob sodelovanju z domačimi in tujimi partnerji z vojaškim raziskovanjem, ustvarjanjem in pridobivanjem vojaškega znanja ter razvojem vojaških znanstvenih disciplin, vojaških ved in z njimi povezanih ved, na katerih temeljijo njihovi študijski programi, zaradi izvajanja poslanstva Slovenske vojske izvaja vojaško izobraževanje in znanstvenoraziskovalno delo na področju vojaških ved. Pedagoška dejavnost bo poleg poučevanja obsegala usposabljanje za učitelje in mentorje, učiteljske konference, sodelovanje na simpozijih s področja izobraževanja, izmenjavo učiteljev, izbor učiteljskega kadra in odobravanje tem zaključnih nalog. Poleg pedagoške vloge učiteljev bo njihova skrb tudi znanstvenoraziskovalno delo v okviru predmeta, ki ga bodo poučevali. Skrbeli bodo za nastajanje novih vojaškostrokovnih besedil in udeležence VIU spodbujali h kakovostnemu pisanju o vojaških vsebinah, razvijali vojaško stroko in javno predstavljali vojaški poklic. Pomemben del bi predstavljalo tudi področje učenja iz izkušenj. S statusom inštituta bi omogočali pogoje za samostojno znanstvenoraziskovalno delo pedagoškim delavcem in sodelovanje pri mednarodnih raziskovalnih projektih. Izobraževalni programi bi se pripravili skupaj z zainteresiranimi fakultetami, na katerih bi se izvajali programi za pridobitev izobrazbe in študijski programi za izpopolnjevanje, in sicer za častnike na vseh treh 
bolonjskih stopnjah, za podčastnike pa na srednji, višji in visoki strokovni stopnji (Predlog, 2014).

\subsection{SV skupaj s partnerskimi izobraževalnimi in znanstvenoraziskovalnimi ustanovami $v$ posebnem vojaškem/častniškem modulu akreditira programe vojaškega izobraževanja}

Temelj razvoja novega sistema vojaškega izobraževanja (VIU) Slovenske vojske je vsekakor Doktrina vojaškega izobraževanja in usposabljanja iz leta 2013. Ta daje izhodišča za programiranje, organiziranje, izvedbo, analizo in evalvacijo vojaškega izobraževanja in usposabljanja v Slovenski vojski, kar je podlaga za zagotovitev nujne stopnje znanja, usposobljenosti in moralne integritete slovenskih vojakov ter pogoj za uresničevanje poslanstva in nalog Slovenske vojske. Doktrina VIU temelji na vojaški doktrini in upošteva priporočila ter zahteve na področju vojaškega izobraževanja in usposabljanja zveze Nato in usmeritve, ki izhajajo iz skupne varnostne in obrambne politike EU ter izhodišča in usmeritve, ki izhajajo iz razvojno-usmerjevalnih dokumentov na obrambnem področju. Vojaška doktrina, ki usmerja delovanje vojske, je podlaga za razvoj vojaških ved in znanosti, taktike, tehnik in postopkov za delovanje vojske v različnih okoliščinah, zato je tudi glavno izhodišče za oblikovanje učnih programov vojaškega izobraževanja in usposabljanja. $\mathrm{Na}$ področju vojaškega izobraževanja in usposabljanja se uveljavljajo kakovostna merila, ki veljajo v javnem izobraževalnem sistemu Republike Slovenije. Programi na vojaških šolah so organizirani kot šolski programi, izvajalci izobraževanja pa morajo izpolnjevati predpisane merila in zahteve. Doktrina podpira transformacijski proces Slovenske vojske, uveljavlja nova načela na področju izobraževanja in usposabljanja ter nove in višje kakovostne zahteve za udeležence in izvajalce, spodbuja nove načine razmišljanja o vsebini VIU, ki se mora povezati s sistemom javnega izobraževanja ter doseči primerljive standarde.

Analiza mogočih rešitev razvoja vojaškega izobraževanja je pred leti pokazala, da je za razvoj vojaške stroke in vojaških ved najprimernejša ustanovitev samostojnega javnega visokošolskega zavoda $v$ večjem povezovanju vojaškega izobraževanja $s$ civilnimi izobraževalnimi ustanovami in vzpostavljanju pogojev za akreditiranje programov vojaškega šolanja skladno z merili, ki veljajo za višješolski študij ter I. in II. stopnjo bolonjskega študija. Z integracijo vojaškega in civilnega izobraževanja $\mathrm{v}$ skupnih programih (akreditiranih pri civilnih, javnih višjih in visokošolskih izobraževalnih zavodih) bi kandidati za podčastnike in častnike po končanem izobraževanju imeli javno priznano znanje, ki ga bodo lahko uporabili tako v vojaških kot tudi civilnih poklicih tehnično in menedžersko - upravljavskega značaja. Trenutno ima Slovenska vojska kakovostno izobraževanje, vendar pa se pridobljeni znanje in spretnosti upoštevajo izključno za napredovanja in delo v SV, zunaj SV pa nimajo nobene veljave. Zato bi bili najbolj smiselni preoblikovanje CVŠ v izobraževalni zavod znotraj SV, akreditacija vojaških programov v terciarnem izobraževanju in izvajanje specializacije $\mathrm{v}$ poveljstvih in enotah SV skladno $\mathrm{z}$ enotnimi merili ter nadzorom CVŠ. CVŠ bi tako v sodelovanju z zainteresiranimi srednjimi in višjimi šolami ter fakultetami dijakom in študentom omogočal znanje, 
ki ga potrebujejo častniki in podčastniki Slovenske vojske, razvoj znanja na vojaškem, obrambnem in varnostnem področju, hkrati pa bi zagotavljal andragoški prenos znanja s področja vojaškega voditeljstva, vojaške logistike, vojaškega prava, vojaške sociologije, vojaške psihologije ter drugih družboslovnih področij. CVŠ bi opravljal izobraževalno in znanstvenoraziskovalno dejavnost, ki temelji na teh študijskih področjih. MO in SV bi tako za vsako študijsko leto razpisala določeno število štipendij za izobraževanje oziroma študij na izbranih fakultetah. Skupni programi CVŠ in fakultet bi se izvajali za pripadnike SV, MO, državnih ustanov in tujce v slovenskem jeziku, predmeti bi potekali tudi v angleščini, kar bi omogočalo večjo primerljivost z vojaškimi izobraževalnimi ustanovami v zavezništvu (Predlog, 2014).

Osnovno izobrazbo in s tem poklic častnika na začetni stopnji (poročnik) je mogoče povezati z akreditiranimi programi 1 . bolonjske stopnje ter $\mathrm{z}$ internim programom ŠČ, ki se akreditira na partnerski izobraževalni ustanovi kot vojaški častniški modul. Prav tako se za višjega častnika (major, podpolkovnik) povežejo akreditirani programi na 2 . bolonjski stopnji z internim programom višjega štabnega šolanja PŠŠ, kjer se oblikuje višji vojaški, častniški modul. Tako se poveča kakovost in skrajša čas dosedanjega internega izobraževanja. Nosilci in izvajalci izbirnih predmetov so habilitirani učitelji in visokošolski sodelavci, zaposleni ali zunanji sodelavci Inštituta vojaških ved Slovenske vojske. Za učitelje in visokošolske sodelavce, ki že imajo veljavno habilitacijo, ponovna habilitacija ni nujna. Postopek habilitacije izvede matična fakulteta. Stroške njihovega dela krije Slovenska vojska. Izbirni predmeti - vojaški modul se izvajajo v prostorih, na vadiščih in streliščih ter z opremo Slovenske vojske, ki krije materialne stroške v obliki zagotovitve nujne osebne opreme za študente ter za izvedbo posameznih predmetov in delovne prakse.

Ob tem se kot interne oblike vojaškega izobraževanja in usposabljanja ohranijo tiste, ki imajo funkcijo strokovnega izpopolnjevanja.

\subsection{SV zagotovi z akreditiranimi programi partnerskih izobraževalnih in znanstvenoraziskovalnih ustanov visoko kvalificiran častniški kader različnih smeri}

Uspešno končani izbirni predmeti modula in diploma bi bili tako pogoj za zaposlitev za poklicno opravljane častniškega poklica v Slovenski vojski ali njeni prostovoljni rezervi. Kot izbirne predmete bi jih lahko izbrali vsi študenti fakultet in visokošolskih zavodov partnerske ustanove, univerze. Tako bi se izjemno povečali prepoznavnost in interes za vojaški poklic v civilnih izobraževalnih ustanovah ter možnost, da vojska dobi diplomante poklicnih smeri, ki jih potrebuje za svoj razvoj. 


\section{NEVARNOSTI ZA RAZVOJ SISTEMA VOJAŠKEGA IZOBRAŽEVANJA V SLOVENSKI VOJSKI}

\subsection{Sprejem političnega soglasja v Republiki Sloveniji, da je SV nosilec razvoja vojaških ved in vojaškega poklica}

Srednjeročni obrambni program Republike Slovenije 2016-2020 daje v poglavju o vojaškem izobraževanju podlago za povezovanje z javnim izobraževalnim sistemom oziroma vzpostavitev bolonjskega izobraževalnega sistema v Slovenski vojski (SOPR, 2015). Podobno je zapisano v viziji načelnika Generalštaba Slovenske vojske za leti 2017 in 2018 (Vizija, 2016): »Vojaški izobraževalni sistem oblikovati tako, da bo približal izobraževanje vojaških profesionalcev standardom, veljavnim v civilnem izobraževalnem sistemu, ter vojaškim izobraževalnim sistemom zavezniških držav«. Pot k temu cilju na politični ravni je tudi ustanovitev medresorske delovne skupine med Ministrstvom za obrambo in Ministrstvom za izobraževanje, znanost in šport, katere namen je proučiti možnosti povezave internega vojaškega z javno akreditiranim izobraževalnim sistemom. To pomeni, da politično soglasje po tem vprašanju obstaja.

\subsection{Neuspeli dosedanji poskus ustanovitve vojaške izobraževalne ustanove, ki bi delovala skladno z bolonjskim sistemom (leta 2007)}

Z Ustanovnim elaboratom za formiranje izobraževalne institucije v Slovenski vojski so bile opredeljene možnosti za ustanovitev visokošolske in višješolske ustanove, saj je imel sistem izobraževanja in usposabljanja v Slovenski vojski večinoma značaj funkcionalnega izobraževanja in usposabljanja z interno veljavnostjo in ni imel veljave $\mathrm{v}$ javnem sistemu. Ministrstvo za obrambo si je ob upoštevanju uvajanja bolonjskega sistema izobraževanja $\mathrm{v}$ visoko šolstvo ter $\mathrm{z}$ ustanovitvijo vojaške fakultete želelo zagotoviti optimalen razvoj izobraževalne in znanstvenoraziskovalne dejavnosti na področju vojaških ved in vključiti področje vojaškega izobraževanja v sistem javnega šolstva. Z ustanovitvijo javno priznane ustanove za izobraževanje častnikov in podčastnikov bi imeli pripadniki SV po končanem izobraževanju diplomo in javno priznano znanje, ki bi ga lahko uporabili tudi v civilnih poklicih. Elaborat zaradi političnih sprememb leta 2008 ni bil sprejet (Elaborat, 2007).

\subsection{Neuspeli poskus preoblikovanja Centra vojaških šol iz poveljstva SV v izobraževalno ustanovo, ki bi se s "skupnimi programi« povezovala v bolonjski sistem (2014)}

GŠSV je, ob zavrnitvi Predloga CVŠ: »s ciljem razvoja sistema VIU ocenil, da je treba na strateški ravni najprej izdelati vizijo razvoja sistema VIU (v nadaljevanju besedila: vizija), ki bo definirala poslanstvo in vizijo ter strateške izzive in usmeritve za razvoj sistema VIU. Vizija bo pogled naprej in bo podlaga za izdelavo nove doktrine VIU, izvedbenih predpisov za pravno formalno ureditev VIU in drugi aktov za urejanje področja VIU, za predloge sprememb predpisov (v smislu iskanja optimalnih zakonskih podlag za implementacijo strateških izzivov), oblikovanje srednjeročnih ciljev razvoja sistema VIU v Srednjeročnem obrambnem programu 
2015-2020 in konkretizacijo v poslovnih planih«. V zvezi s tem je bila 2014 ustanovljena delovna skupina za razvoj vojaškega izobraževanja, ki pa svojega dela ni niti dobro začela (Predlog, Zavrnitev predloga, 2014).

Sklep Naš cilj mora biti, da z osnovnim vojaškostrokovnim izobraževanjem izobrazimo in usposobimo podčastnike in častnike za opravljanje temeljnih nalog podčastnika in častnika. Poteka naj kot javni izobraževalni program in daje podčastniku ter častniku javno priznano izobrazbo. Nadaljevalno vojaškostrokovno izobraževanje podčastnikov in častnikov ter usposabljanje vojakov naj bo namenjeno strokovnemu izpopolnjevanju vojaških oseb za opravljanje višjih in zahtevnejših dolžnosti ter pridobitvi višje vojaškostrokovne izobrazbe in usposobljenosti, ki omogoča vojaškostrokovni razvoj in napredovanje v činu. Poklicni sistem v SV pa je v končni obliki zastavljen tako, da temelji na sistemu vojaškega izobraževanja, kar pomeni, da je uspešno končano vojaško izobraževanje doma ali v tujini temeljni pogoj za opravljanje dolžnosti na vseh ravneh v SV. Prišel je čas, da vojaško profesijo izpopolnimo tako, da organiziramo in akreditiramo vojaško izobraževalno ustanovo. Ne samo zato, ker smo se za to obvezali v zavezništvu; v Natu namreč že poteka pospešen proces organiziranja, preverjanja, akreditiranja visokošolskih vojaških ustanov, skladno z bolonjskim sistemom, in večina Natovih držav je ta postopek že opravila. Preurediti jo je treba predvsem zaradi nas in naše vojaške znanosti, saj imamo dobre temelje $\mathrm{v}$ dolgi vojaški tradiciji ter v vojaških intelektualcih, kot so bili Jurij Vega, Rudolf Maister, Vladimir Vauhnik in drugi. Izobraževalna ustanova bi omogočila resen razvoj in napredek slovenske vojaške stroke ter posledično Slovenske vojske. V povezavi z zavezništvi pa bi omogočila, da bi poslanstvo, ki ga opravljamo, temeljilo na našem zanju, ki bi ga na enakopravnih temeljih delili z drugimi ustanovami, vojaškimi in civilnimi, tako doma kot v tujini.

\section{Literatura}

1. Pisanski, Tomaž, ur. (2006): Baron Jurij Vega in njegov čas, Ljubljana:DMFAzaložništvo in Arhiv Republike Slovenije.

2. Brožič, Liliana (2009): Izobraževanje v oboroženih silah. V Rajkovič Vladislav, ur.: Nove tehnologije, novi izzivi: zbornik 28. mednarodne konference o razvoju organizacijskih znanosti. Kranj: Moderna organizacija, 223-229.

3. Brožič, Liliana (2014): 15 let izhajanja Sodobnih vojaških izzivov. www.slovenskavojska. si/vojaski.izzivi.

4. Doktrina vojaškega izobraževanja in usposabljanja, 2013. Ljubljana: Ministrstvo za obrambo Republike Slovenije.

5. Kadetnica, 2011. Ljubljana: Defensor.

6. Kladnik, Tomaž (2007): Slovenska vojska v službi domovine. Ljubljana: Defensor.

7. Kotnik, Igor (2008): Raznolikost izobraževanja vojaških častnikov. V: Rajkovič Vladislav, ur: Znanje za trajnostni razvoj: zbornik 27. mednarodne konference o razvoju organizacijskih znanosti. Kranj: Moderna organizacija, 1126-1140.

8. NATO Education and Training Directive (E\&TD) Bi-SC 75-2, 2013. Norfolk:

9. Predlog razvoja CVŠ v obdobju 2014-2016 (2018), 2015. Maribor: Center vojaških šol.

10. Pešec, Mojca, Krek, Uroš (2015): Can the process of professional military education create military strategists. Sodobni vojaški izzivi, 17-4, 47-61.

11. Standardni operativni postopki za delovanje CVŠ, 2015. Maribor: Center vojaških šol. 
12. Srednjeročni obrambni program Republike Slovenije 2016-2020, 2016. Ljubljana: Ministrstvo za obrambo Republike Slovenije.

13. Toš, Dušan, 2011. Slovensko vojaško šolstvo, zamujena priložnost in izzivi v prihodnosti, Sodobni vojaški izzivi, 13-2, 99-121.

14. Ustanovni elaborat za formiranje izobraževalne institucije v Slovenski vojski (2007), Ljubljana: Poveljstvo za doktrino, razvoj, izobraževanje in usposabljanje.

15. Vaupotič, Karmen, Pavlič, Urška, Rugelj, Tomislav, Hrženjal, Majda, Janusch, Eva, Gaube, Heidi (2012): Ugotavljanje potreb po izobraževanju skladno s potrebami trga dela. Maribor: Fundacija za izboljšanje zaposlitvenih možnosti PRIZMA.

16. Vegič, Vinko, Zabukovec, Stojan (2014): Izobraževanje častnikov: od razpravo organiziranosti k razmisleku o vsebinah. Sodobni vojaški izzivi, 16-2, 57-73.

17. Vizija načelnika Generalštaba Slovenske vojske za leti 2017 in 2018 (2016). Ljubljana: Generalštab Slovenske vojske.

18. Zavrnitev Predloga razvoja CVŠ v obdobju 2014-2016 (2018), 2015. Ljubljana: Generalštab Slovenske vojske.

19. Žabkar, Anton in Svete, Uroš (2007): Šolanje vojaških profesionalcev med tradicionalnimi izhodišči in (post)modernimi izzivi. Bilten Slovenske vojske, 10-1, 183.

20. Žabkar, Anton (2003). Marsova dediščina. Ljubljana: Fakulteta za družbene vede. 


\section{ANALIZA SWOT}

Povezovanje vojaškega izobraževalnega in znanstvenoraziskovalnega sistema $\mathrm{v}$ Slovenski vojski s sistemom izobraževanja in znanstvenoraziskovalnega dela $\mathrm{v}$ Republiki Sloveniji in mednarodnem okolju.

\section{SLOVENSKA VOJSKA}

\begin{tabular}{|c|c|}
\hline PREDNOSTI (znotraj, pozitivne): & SLABOSTI (znotraj, negativne): \\
\hline $\begin{array}{l}\text { - ima oblikovan interni sistem vojaškega } \\
\text { izobraževanja in usposabljanja, ki v temeljih } \\
\text { deluje nespremenjen od leta 1992; } \\
\text { - ima več kot } 20 \text { doktorjev znanosti in več drugih } \\
\text { strokovnjakov, ki bi jih ob ustreznem kadrovskem } \\
\text { izboru ter poklicni poti usmerili v razvoj vojaških } \\
\text { ved; } \\
\text { - ima odlično opremo in infrastrukturo za izvedbo } \\
\text { izobraževalnega ter znanstvenoraziskovalnega } \\
\text { dela; } \\
\text { - ima knjižnično-informacijski in založniški center; } \\
\text { - ima svojo znanstveno-strokovno publikacijo; } \\
\text { - v omejenem obsegu razpolaga z ustreznimi } \\
\text { financami; } \\
\text { - ima dostop in možnost povezovanja ter izmenjave } \\
\text { učiteljev in študentov ter vključevanje v ZR- } \\
\text { projekte v Natu in EU. }\end{array}$ & $\begin{array}{l}\text { - ni nosilec razvoja vojaških ved in posledično } \\
\text { vojaškega poklica; } \\
\text { - nima oblikovane osrednje pedagoške in } \\
\text { znanstvenoraziskovalne ustanove; } \\
\text { - nima oblikovanega izobraževalnega in } \\
\text { znanstvenoraziskovalnega sistema ter } \\
\text { izoblikovanih in razvitih znanstvenih disciplin } \\
\text { vojaških ved z ustreznimi nosilci, ki bi se } \\
\text { vključevali v (civilno) javno in mednarodno } \\
\text { vojaško pedagoško in znanstvenoraziskovalno } \\
\text { okolje; } \\
\text { - nima javno akreditiranih programov } \\
\text { izobraževanja. }\end{array}$ \\
\hline PRILOŽNOSTI (zunaj, pozitivne): & NEVARNOSTI (zunaj, negativne): \\
\hline $\begin{array}{l}\text { - SV skupaj s partnerskimi izobraževalnimi in } \\
\text { znanstvenoraziskovalnimi ustanovami: } \\
\text { - postane nosilec razvoja vojaških ved in posledično } \\
\text { vojaškega poklica; } \\
\text { - s svojimi kadri vzpostavi osrednjo pedagoško in } \\
\text { znanstvenoraziskovalno ustanovo v obliki inštituta } \\
\text { vojaških ved; } \\
\text { - oblikuje izobraževalni in znanstvenoraziskovalni } \\
\text { sistem ter izoblikuje in razvija znanstvene } \\
\text { discipline vojaških ved z ustreznimi nosilci, ki so } \\
\text { vključeni v (civilno) javno in mednarodno vojaško } \\
\text { pedagoško in znanstvenoraziskovalno okolje; } \\
\text { - zagotovi visoko kvalificiran častniški kader } \\
\text { različnih smeri; } \\
\text { • v posebnem častniškem modulu akreditira } \\
\text { programe vojaškega izobraževanja. }\end{array}$ & $\begin{array}{l}\text { - politično soglasje, da je SV nosilec razvoja } \\
\text { vojaških ved in posledično vojaškega poklica; } \\
\text { - neuspeli dosedanji poskus ustanovitve svoje } \\
\text { vojaškoizobraževalne ustanove, ki bi delovala } \\
\text { skladno z bolonjskim sistemom (leta 2007); } \\
\text { - neuspeli poskus preoblikovanja Centra vojaških } \\
\text { šol iz poveljstva SV v izobraževalno ustanovo, ki bi } \\
\text { se s »skupnimi programi« povezovala v bolonjski } \\
\text { sistem (2014). }\end{array}$ \\
\hline
\end{tabular}

Avtor: Tomaž Kladnik 
Avtorji

Authors 


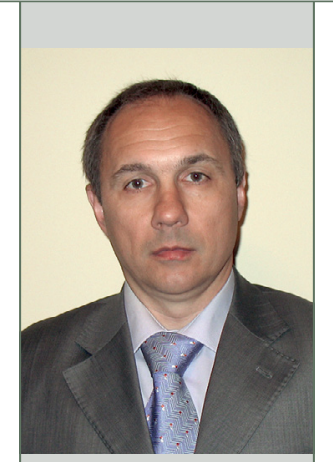

Pavel Vuk

Mag. Pavel Vuk je univerzitetni diplomirani politolog in magister politoloških znanosti, oba študija je končal na Fakulteti za družbene vede v Ljubljani. Na Ministrstvu za obrambo je zaposlen od leta 1992. V obdobju 2011-2015 je vodil Sektor za strateško planiranje v Direktoratu za obrambno politiko, od leta 2016 pa deluje v Centru vojaških šol na Katedri vojaških ved kot učitelj za strategijo in operatiko. Posebno dejaven je na področjih nacionalne varnosti in obrambe ter mednarodne varnosti in obrambnega načrtovanja. Je avtor številnih strokovnih člankov s teh področij, objavljenih v slovenskih publikacijah.

Pavel Vuk, MSc, holds bachelor's and master's degrees in Political Sciences, both from the Faculty of Social Sciences in Ljubljana. He has been employed at the Ministry of Defence since 1992. Between 2011 and 2015, he headed the Strategic Planning Division within the Defence Policy Directorate and, since 2016, he has been working at the Chair of Military Sciences of the Military Schools Centre as a teacher of strategy and operational art. He is particularly engaged in the areas of national security and defence, international security and defence planning. He has authored numerous scientific articles on the aforementioned subjects published in Slovenian publications.

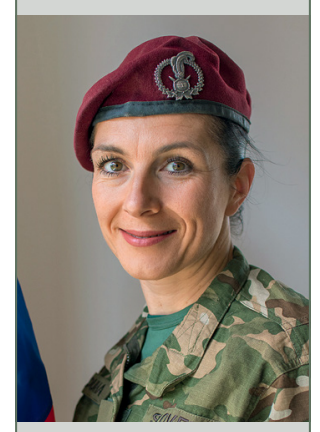

Nina Raduha

Majorka mag. Nina Raduha je univerzitetna diplomirana politologinja, smer obramboslovje. $\mathrm{Na}$ Pravni fakulteti $\mathrm{V}$ Ljubljani je magistrirala iz kazenskega prava. V Slovenski vojski je zaposlena od leta 2003, sodelovala je tudi na misiji v BiH. Leta 2016 je kot najboljša slušateljica končala višje štabno šolanje. Na šoli za obrambno komuniciranje v ZDA je z odliko končala tečaj odnosov z javnostmi. Opravila je vse poveljniške dolžnosti do ravni čete, bila je častnica za odnose z javnostmi in za informacijsko delovanje ter urednica več publikacij.

Major Nina Raduha, MSc, holds a bachelor's degree in political science (defence studies). She earned her master's degree in criminal law science from the Faculty of Law in Ljubljana. She has worked in the SAF since 2003 and has been deployed once to Bosnia and Herzegovina. In 2016, she completed the Senior Staff Programme as the best student. At the Defence Information School, USA, she completed the Public Affairs Course with distinction. She has performed all commanding duties up to the company-level and has worked as a Public Affairs and InfoOps officer. She has been editor of several publications. 


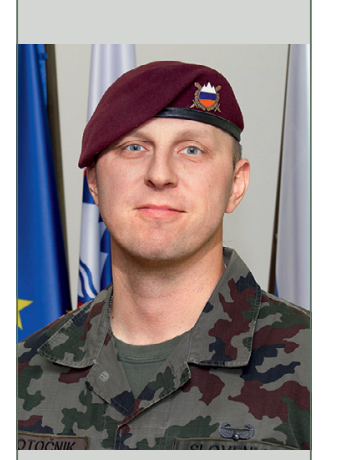

Viktor Potočnik
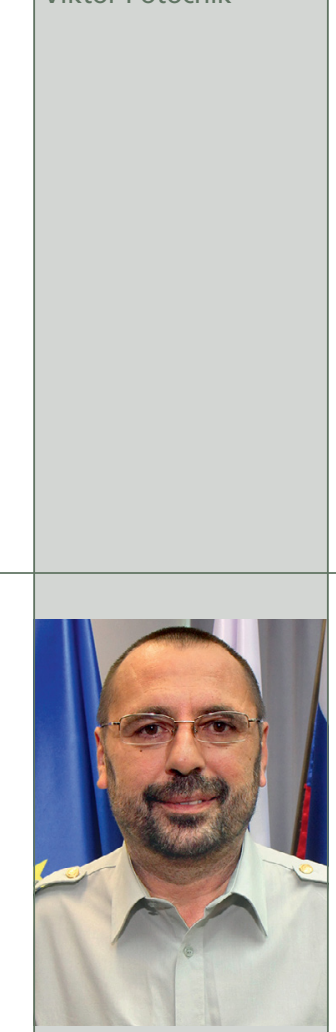

Vinko Vegič

Major mag. Viktor Potočnik je v Slovenski vojski zaposlen od leta 2001. Bil je poveljnik motoriziranega voda, minometne čete in motorizirane čete $\mathrm{v}$ mirovni operaciji ter načelnik S-3 v 1. brigadi Slovenske vojske. Udeležil se je treh mirovnih operacij in misij ter opravil več izobraževanj in usposabljanj v tujini, predvsem s področja združene ognjene podpore. Leta 2011 je končal višje štabno šolanje na CGSC v Fort Leavenworthu v ZDA in pridobil naziv Master of Military Arts and Science. Od leta 2013 dela v Generalštabu Slovenske vojske.

Major Viktor Potočnik, MSc, has been commissioned since 2001. So far, he has performed duties of a Motorised Platoon Commander, Mortar Company Commander, Motorised Company Commander on deployment, and Chief, $S$ - 3 of the $1^{\text {st }}$ Brigade. He has been deployed three times, and has attended several career and functional training courses abroad, mainly in the field of joint fire support. In 2011, he completed Senior Staff Course at CGSC, Fort Leavenworth, USA and obtained the title Master of Military Arts and Science. Since 2013, he has been working at the SAF General Staff.

\section{Višji vojaški uslužbenec XIV. razreda dr. Vinko Vegič je} doktoriral iz obramboslovnih znanosti. Bil je raziskovalec in predavatelj na Katedri za obramboslovje na Fakulteti za družbene vede. Področja njegovega raziskovalnega in pedagoškega dela so nacionalna in mednarodna varnost, sodobne varnostne strategije ter vojaške organizacije. V Slovenski vojski je zaposlen od leta 2008. Do leta 2013 je delal v vojaškem izobraževalnem sistemu, bil je tudi načelnik Katedre za nacionalno obrambo, trenutno pa dela v Združenem sektorju za strateško planiranje Generalštaba Slovenske vojske.

\section{Senior Military Specialist, Class XIV, Vinko Vegič, PhD,} holds a PhD in Defence Studies. He has worked as a researcher and lecturer at the Chair of Defence Studies at the Faculty of Social Sciences. The areas of his research and educational work include national and international security, modern security strategies and military organizations. He has worked in the Slovenian Armed Forces (SAF) since 2008. Until 2013, he was engaged in the military education system, also as Head of the Chair of National Security. Currently, he works at the Joint Strategic Planning Division of the SAF General Staff. 


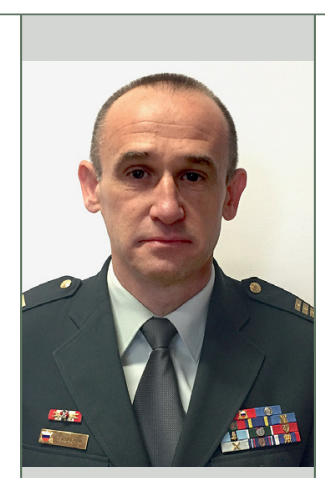

Tomaž Kladnik

Polkovnik dr. Tomaž Kladnik je izredni profesor, doktoriral je leta 2005 na Pedagoški fakulteti v Mariboru, smer zgodovina. Tema njegove doktorske disertacije je bila Slovensko vojaško šolstvo in vojaške operacije (1941-1945). V Slovenski vojski se je zaposlil leta 1992. V svoji vojaški karieri je opravljal več različnih dolžnosti. Od leta 2013 je načelnik Katedre vojaških ved in dekan v Centru vojaških šol. Je nosilec predmeta vojaška zgodovina na Filozofski fakulteti Univerze $\mathrm{v}$ Mariboru in predmeta vojaško voditeljstvo na generalštabnem šolanju Poveljniško-štabne šole.

Colonel Tomaž Kladnik, PhD, is Associated Professor. He earned his PhD in history from the Faculty of Education in Maribor in 2005 with a thesis Slovene military education and military operations (1942 - 1945). He joined the Slovenian Armed Forces in 1992 and has performed several duties throughout his military career. Since 2013, he has been Chief of the Chair of Military Sciences and a dean at the Military Schools Centre. He is also head of the subject Military Leadership in the General Staff Course of the SAF Command and Staff School. 


\section{Navodila avtorjem za oblikovanje prispevkov Instructions for the authors of papers}




\section{NAVODILA AVTORJEM ZA OBLIKOVANJE PRISPEVKOV ZA SODOBNE VOJAŠKE IZZIVE IN VOJAŠKOŠOLSKI ZBORNIK}

\section{Vsebinska navodila}

Splošno

Sodobni vojaški izzivi je interdisciplinarna znanstveno-strokovna publikacija, ki objavlja prispevke o aktualnih temah, raziskavah, znanstvenih in strokovnih razpravah, tehničnih ali družboslovnih analizah z varnostnega, obrambnega in vojaškega področja.

Vojaškošolski zbornik je vojaškostrokovna in informativna publikacija, namenjena izobraževanju in obveščanju o dosežkih ter izkušnjah na področju vojaškega izobraževanja, usposabljanja in izpopolnjevanja.

Kaj objavljamo?

Objavljamo prispevke v slovenskem jeziku s povzetki, prevedenimi v angleški jezik, in po odločitvi uredniškega odbora prispevke v angleškem jeziku s povzetki, prevedenimi v slovenski jezik.

Objavljamo prispevke, ki še niso bili objavljeni ali poslani v objavo drugi reviji. Pisec je odgovoren za vse morebitne kršitve avtorskih pravic. Če je bil prispevek že natisnjen drugje, poslan v objavo ali predstavljen na strokovni konferenci, naj to avtor sporočiti uredniku in pridobiti soglasje založnika (če je treba) ter navesti razloge za ponovno objavo.

\section{Tehnična navodila}

Omejitve dolžine prispevkov

Recenzije
Prispevki naj obsegajo 16 strani oziroma 30.000 znakov s presledki (avtorska pola), izjemoma najmanj 8 strani oziroma 15.000 znakov ali največ 24 strani oziroma 45.000 znakov.

Prispevki se recenzirajo. Recenzija je anonimna. Glede na oceno recenzentov uredniški odbor ali urednik prispevek sprejme, če je treba, zahteva popravke ali ga zavrne. Pripombe recenzentov avtor vnese v prispevek.

Zaradi anonimnega recenzentskega postopka je treba prvo stran in vsebino oblikovati tako, da identiteta avtorja ni prepoznavna.

Avtor ob naslovu prispevka napiše, v katero kategorijo po njegovem mnenju in glede na klasifikacijo v COBISS spada njegov prispevek. Klasifikacija je dostopna na spletni strani revije in pri odgovornem uredniku. Končno klasifikacijo določi uredniški odbor. 
Lektoriranje Lektoriranje besedil zagotavlja OE, pristojna za založniško dejavnost. Lektorirana besedila se avtorizirajo.

Prevajanje Prevajanje besedil ali povzetkov zagotavlja OE, pristojna za prevajalsko dejavnost oziroma Šola za tuje jezike Centra vojaških šol.

Navajanje Navajanje avtorjev je skrajno zgoraj, levo poravnano.

avtorjev Primer:

prispevka Ime 1 Priimek 1,

Ime 2 Priimek 2

V opombi pod črto se za slovenske avtorje navede, iz katere ustanove prihajajo. Pri tujih avtorjih je treba navesti tudi ime države.

Naslov

Navedbi avtorjev sledi naslov prispevka. Črke v naslovu so velike 16 pik, natiprispevka snjene krepko, besedilo naslova pa poravnano na sredini.

Povzetek Prispevku mora biti dodan povzetek, ki obsega največ 1200 znakov (20 vrstic). Povzetek naj na kratko opredeli temo prispevka, predvsem naj povzame rezultate in ugotovitve. Splošne ugotovitve in misli ne spadajo v povzetek, temveč v uvod.

Povzetek Avtorji morajo oddati tudi prevod povzetka v angleščino. Tudi za prevod povzetka v angleščini velja omejitev do 1200 znakov (20 vrstic).

Ključne

besede

Ključne besede (3-5, tudi $\mathrm{v}$ angleškem jeziku) naj bodo natisnjene krepko in $\mathrm{z}$ obojestransko poravnavo besedila.

Besedilo Avtorji naj oddajo svoje prispevke na papirju formata A4, s presledkom med vrsticami 1,5 in velikostjo črk 12 pik Arial. Na zgornjem in spodnjem robu naj bo do besedila približno $3 \mathrm{~cm}$, levi rob naj bo širok $2 \mathrm{~cm}$, desni pa $4 \mathrm{~cm}$. Na vsaki strani je tako približno 30 vrstic s približno 62 znaki. Besedilo naj bo obojestransko poravnano, brez umikov na začetku odstavka.

Kratka Avtorji morajo pripraviti kratko predstavitev svojega strokovnega oziroma znanpredstavitev stvenega dela. Predstavitev naj ne presega 600 znakov (10 vrstic, 80 besed). Če avtorjev je avtorjev več, se predstavi vsak posebej, čim bolj zgoščeno. Avtorji naj besedilo umestijo na konec prispevka po navedeni literaturi. 
Strukturiranje besedila
Posamezna poglavja $\mathrm{v}$ besedilu naj bodo ločena s samostojnimi podnaslovi in ustrezno oštevilčena (členitev največ na 4 ravni).

Primer:

1 Uvod

2 Naslov poglavja (1. raven)

2.1 Podnaslov (2. raven)

2.1.1 Podnaslov (3. raven)

2.1.1.1 Podnaslov (4. raven)
Oblikovanje seznama literature
Navajanje virov z interneta
V seznamu literature je treba po abecednem redu navesti le avtorje, na katere se sklicujete $\mathrm{v}$ prispevku, celotna oznaka vira pa mora biti skladna s harvardskim načinom navajanja. Če je avtorjev več, navedemo vse, kot so navedeni na izvirnem delu.

Primeri:

a) knjiga:

Priimek, ime (lahko začetnica imena), letnica. Naslov dela. Kraj: Založba.

Na primer:Urlich, W., 1983. Critical Heuristics of Social Planning. Chicago: University of Chicago Press.

b) zbornik:

Samson, C., 1970. Problems of information studies in history. V S. Stone, ur. Humanities information research. Sheffield: CRUS, 1980, str./pp. 44-68. Pri posameznih člankih v zbornikih na koncu posameznega vira navedemo strani, na katerih je članek, na primer:

c) članek v reviji

Kolega, N., 2006. Slovenian coast sea flood risk. Acta geographica Slovenica. 46-2, str. 143-167.

Vse reference se začenjajo enako kot pri natisnjenih virih, le da običajnemu delu sledi še podatek o tem, kje na internetu je bil dokument dobljen in kdaj. Podatek o tem, kdaj je bil dokument dobljen, je pomemben zaradi pogostega spreminjanja www okolja.

Urlich, W., 1983. Critical Heuristics of Social Planning. Chicago: University of Chicago Press, str. 45-100. http://www.mors.si/index.php?id=213, 17. 10. 2008. Pri navajanju zanimivih internetnih naslovov v besedilu (ne gre za navajanje posebnega dokumenta) zadošča navedba naslova (http://www.vpvs.uni-lj.si). Posebna referenca na koncu besedila $\mathrm{v}$ tem primeru ni potrebna. 
Sklicevanje na vire

Slike, diagrami in tabele
Opombe pod črto

Kratice

Format zapisa prispevka
Pri sklicevanju na vire med besedilom navedite le priimek prvega avtorja in letnico izdaje. Primer: ... (Smith, 1997) ...

Če dobesedno navajate del besedila, ga ustrezno označite z narekovaji, v oklepaju pa poleg avtorja in letnice navedite stran besedila, iz katerega ste navajali.

Primer: ... (Smith, 1997, str. 15) ...

Pri povzemanju drugega avtorja napišemo besedilo brez narekovajev, v oklepaju pa napišemo, da gre za povzeto besedilo. Primer: (po Smith, 1997, str. 15). Če avtorja navajamo $\mathrm{v}$ besedilu, $\mathrm{v}$ oklepaju navedemo samo letnico izida in stran (1997, str. 15).

Slike, diagrami in tabele v prispevku naj bodo v posebej pripravljenih datotekah, ki omogočajo lektorske popravke. V besedilu mora biti jasno označeno mesto, kamor je treba vnesti sliko. Skupna dolžina prispevka ne sme preseči dane omejitve.

Če avtor iz tehničnih razlogov grafičnih dodatkov ne more oddati v elektronski obliki, je izjemoma sprejemljivo, da slike priloži besedilu. Avtor mora $\mathrm{v}$ tem primeru na zadnjo stran slike napisati zaporedno številko in naslov, $\mathrm{v}$ besedilu pa pustiti dovolj prostora zanjo. Prav tako mora biti besedilo opremljeno $\mathrm{z}$ naslovom in številčenjem slike. Diagrami se štejejo kot slike. Vse slike in tabele se številčijo. Številčenje poteka enotno in ni povezano s številčenjem poglavij. Naslov slike je naveden pod sliko, naslov tabele pa nad tabelo. Navadno je v besedilu navedeno vsaj eno sklicevanje na sliko ali tabelo. Sklic na sliko ali tabelo je: ... (slika 5) ... (tabela 2$) \ldots$

Primer slike: $\quad$ Primer tabele:

Tabela 2: Naslov tabele

Slika 5: Naslov slike

Številčenje opomb pod črto je neodvisno od strukture besedila in se v vsakem prispevku začne s številko 1. Posebej opozarjamo avtorje, da so opombe pod črto namenjene pojasnjevanju misli, zapisanih v besedilu, in ne navajanju literature.

Kratice naj bodo dodane v oklepaju, ko se okrajšana beseda prvič uporabi, zato posebnih seznamov kratic ne dodajamo. Za kratico ali izraz v angleškem jeziku napišemo najprej slovensko ustreznico, v oklepaju pa angleški izvirnik in morebitno angleško kratico.

Uredniški odbor sprejema prispevke, napisane z urejevalnikom besedil MS Word, izjemoma tudi v besedilnem zapisu (text only). 
Naslov Prispevkom naj bosta dodana avtorjeva naslov in internetni naslov ali telefonska avtorja številka, na katerih bo dosegljiv uredniškemu odboru.

Kako poslati Na naslov uredništva ali članov uredniškega odbora je treba poslati tiskano in eleprispevek ktronsko različico prispevka.

Potrjevanje Uredniški odbor avtorju pisno potrdi prejetje prispevka. Avtorjem, ki sporočijo sprejetja tudi naslov svoje elektronske pošte, se potrditev pošlje po tej poti.

prispevka

Korekture Avtor opravi korekture svojega prispevka v treh dneh.

Naslov Ministrstvo za obrambo

uredniškega Generalštab Slovenske vojske

odbora Sodobni vojaški izzivi

Uredniški odbor

Vojkova cesta 55

1000 Ljubljana

Slovenija

Elektronski naslov

Odgovorna urednica:

liliana.brozic@mors.si

Prispevkov, ki ne bodo urejeni skladno s tem navodilom, uredniški odbor ne bo sprejemal. 


\section{INSTRUCTIONS FOR THE AUTHORS OF PAPERS FOR THE CONTEMPORARY MILITARY CHALLENGES AND THE MILITARY EDUCATION JOURNAL}

\section{Content-related instructions}

General The Contemporary Military Challenges is an interdisciplinary scientific expert magazine, which publishes papers on current topics, researches, scientific and expert discussions, technical or social sciences analysis from the field of security, defence and the military..

The Military Education Journal is a military professional and informative publication intended for education and informing on achievements and experiences in the field of military education, training and improvement.

What do we publish?

We publish papers in Slovene with abstracts translated into English. If so decided by the Editorial Board, we also publish papers in English with abstracts translated into Slovene.

We publish papers, which have not been previously published or sent to another magazine for publication. The author is held responsible for all possible copyright violations. If the paper has already been printed elsewhere, sent for publication or presented at an expert conference, the author must notify the editor, obtain the publisher's consent (if necessary) and indicate the reasons for republishing.

\section{Technical instructions}

Limitations regarding the length of the papers
The papers should consist of 16 typewritten double-spaced pages or 30,000 characters. At a minimum they should have 8 pages or 15,000 characters and at a maximum 24 pages or 45,000 characters. 
Reviews All papers are reviewed. The review is anonymous. With regard to the reviewer's assessment, the Editorial Board or the editor accepts the paper, demands modifications, if necessary, or rejects it. Upon receiving the reviewers' remarks, the author inserts them into the paper.

Due to an anonymous review process, the first page must be designed in the way that the author's identity cannot be recognized.

Next to the title, the author should indicate the category the paper belongs to according to him and according to the classification in the COBISS ${ }^{1}$. The classification is available on the magazine's internet page and at the responsible editor. The Editorial Board determines the final classification.

Proofreading The organizational unit responsible for publishing provides the proofreading of the papers. The proofread papers have to be approved.

Translating The translation of the papers or abstracts is provided by the organizational unit competent for translation or the School of Foreign Languages, Military Schools Centre.

Indicating The authors' name should be written in the upper left corner, aligned left.

the authors Example:

of the paper Name 1 Surname 1,

Name 2 Surname 2,

In the footnote, Slovenian authors should indicate the institution they come from. Foreign authors should also indicate the name of the state they come from.

Title of the The title of the paper is written below the listed authors. The font in the title is paper bold, size 16 points. The text of the title is centrally aligned.

Abstract The paper should have an abstract of a maximum 1,200 characters (20 lines). The abstract should include a short presentation of the topic, particularly the results and the findings. General findings and reflections do not belong in the abstract, but rather in the introduction.

Abstract in The authors must also submit the translation of the abstract into English. The translaEnglish tion of the abstract is likewise limited to a maximum of 1,200 characters (20 lines).

Key words Key words (3-5 also in the English language) should be bold with a justified text alignment.

Text

The authors should submit their papers on an A4 paper format, with 1.5 line spacing, fontArial size 12 points. At the upper and the bottom edge, there should be approx. $3 \mathrm{~cm}$ of space; the left margin should be $2 \mathrm{~cm}$ wide and the right margin $4 \mathrm{~cm}$. Each page consists of approx. 30 lines with 62 characters. The text should have a justified alignment, without indents at the beginning of the paragraphs. 
A brief pre- The authors should prepare a brief presentation of their expert or scientific work. sentation of The presentation should not exceed 600 characters (10 lines, 80 words). If there the authors are several authors, each should be presented individually, as shortly and as comprehensively as possible. These texts should be placed at the end of the paper, after the cited literature.

Text structuring

Individual chapters should be separated with independent subtitles and adequately numbered.

Example:

1 Introduction

2 Title of the chapter $\left(1^{\text {st }}\right.$ level $)$

2.1 Subtitle ( $\left.2^{\text {nd }} l e v e l\right)$

2.1.1 Subtitle $\left(3^{\text {rd }}\right.$ level $)$

2.1.1.1 Subtitle $\left(4^{\text {th }}\right.$ level $)$

Referencing In the bibliography, only the authors of references one refers to in the paper should be listed, in the alphabetical order. The entire reference has to be in compliance with the Harvard citing style.

Example:

Surname, name (can also be the initial of the name), year. Title of the work. Place. Publishing House.

\section{Example:}

Urlich, W., 1983. Critical Heuristics of Social Planning. Chicago: University of Chicago Press.

With certain papers published in journals, the author should indicate, at the end of each reference, a page on which the paper can be found.

\section{Example:}

Urlich, W., 1983. Critical Heuristics of Social Planning. Chicago: University of Chicago Press. pp. 45-100.

Referencing All references start the same as the references for the printed sources, only that internet sources the usual part is followed by the information about the Internet page on which the document was found as well as the date on which it was found. The information about the time that the document was found on the Internet is important, because the WWW environment changes constantly.

Urlich, W., 1983. Critical Heuristics of Social Planning. Chicago: University of Chicago Press. p. 45-100. http://www.mors.si/index.php?id=213, 17 October 2008.

When referencing interesting WWW pages in the text (not citing an individual document) it is enough to state only the Internet address (http://www.vpvs.uni-lj. si). A separate reference at the end of the text is therefore not necessary. 
Citing

Figures, diagrams, tables
When citing sources in the text, indicate only the surname of the author and the year of publication. Example: (Smith, 1997) ...

When making a direct reference to a text, the cited part should be adequately marked with quotation marks and followed by the exact page of the text which the citing is taken from.

Example: ...(Smith, 1997, p.15) ...

Figures, diagrams and tables in the paper should be prepared in separate files which allow for proofreading corrections. The place in the text where the picture should be inserted must be clearly indicated. The total length of the paper must not surpass the given limitation.

Should the author not be able to submit the graphical supplements in the electronic form due to technical reasons, it is exceptionally acceptable to enclose the figures to the text. In this case the author must write a sequence number and a title on the back of each picture and leave enough space in the text to include it. The text must likewise contain the title and the sequence number of the figure. Diagrams are considered figures.

All figures and tables are numbered. The numbering is not uniform and not linked with the numbering of the chapters. The title of the figure is stated beneath it and the title of the table is stated above it.

As a rule, the paper should include at least one reference to a figure or a table.. Reference to a figure or a table is: ... (Figure 5) (Table 2)

Example of a figure: $\quad$ Example of a table:

Table 2: Title of the table

Figure 5: Title of the figure

Footnotes

The numbering of the footnotes is not related to the structure of the text and starts with number 1 in each paper. We want to stress that the aim of the footnotes is to explain the thoughts written in the text and not to reference literature.

Abbreviati- When used for the first time, the abbreviations in the text must be explained in ons parenthesis; therefore no additional list of abbreviations is needed. If the abbreviations or terms are written in English, the appropriate Slovenian term should be written along with the English original and possibly the English abbreviation in the parenthesis.

Format type The Editorial Board accepts only the texts written with a MS Word text editor and of the paper only exceptionally those in the 'text only' format. 
Author's Each paper should include the author's address, e-mail or a telephone number, so address that the Editorial Board can reach him or her.

Sending A print or an electronic version of the paper should be sent to the address of the the paper Editorial Board or the members of the Editorial Board.

Confirma- The Editorial Board sends the author a written confirmation regarding the tion of the reception of the paper. The authors who also list their e-mails receive the confirreception of mation via e-mail.

the paper

Corrections The author makes corrections to the paper within three days.

$\begin{array}{ll}\text { Editorial } & \text { Ministry of Defence } \\ \text { Board } & \text { Slovenian Armed Forces } \\ \text { address } & \text { General Staff } \\ & \text { Contemporary Military Challenges } \\ & \text { Editorial Board } \\ & \text { Vojkova cesta 55 } \\ & 1000 \text { Ljubljana } \\ & \text { Slovenia } \\ & \text { Electronic address: } \\ & \text { Editor in Chief: } \\ & \text { liliana.brozic@mors.si }\end{array}$

The Editorial Board will not accept papers, which will not be in compliance with the above instructions. 



Sodobni vojaški izzivi - 19/št. 1

Vsebina

Liliana Brožič

UVODNIK: VARNOST KOT IMPERATIV

EDITORIAL: SECURITY AS AN IMPERATIVE

Pavel Vuk

OBRAMBNO PLANIRANJE - NUJEN INSTRUMENT POLITIKE PRI ZAGOTAVLANJU OBRAMBNIH POTREB DRŽAVE

DEFENCE PLANNING - VITAL POLICY INSTRUMENT IN SUPPORTING A NATION'S DEFENCE NEEDS

Nina Raduha

Pavel Vuk

KRIZNO UPRAVUANJE NA OBRAMBNEM PODROČJU S POUDARKOM NA SLOVENSKI VOJSKI

CRISIS MANAGEMENT IN THE FIELD OF DEFENCE, WITH EMPHASIS ON THE SLOVENIAN ARMED FORCES

Viktor Potočnik

ČETRTA GENERACIJA VOJSKOVANJA

3. del: NOV KONCEPT SV ZA DELOVANJE V ČETRTI GENERACIJI VOJSKOVANJA FOURTH GENERATION WARFARE

Part 3: NEW SAF CONCEPT OF OPERATIONS IN FOURTH GENERATION WARFARE

Vinko Vegič

TEMELNO ŠOLANJE ČASTNIKOV V DRŽAVAH EVROPSKE UNIJE -

ISKANJE ODGOVOROV NA SODOBNE ZAHTEVE

BASIC OFFICER TRAINING IN EUROPEAN UNION COUNTRIES - SEEKING ANSWERS TO CONTEMPORARY REQUIREMENTS

Tomaž Kladnik

VOJAŠKO IZOBRAŽEVANJE V SLOVENSKI VOJSKI - IZZIVI PRIHODNOSTI

MILITARY EDUCATION IN THE SLOVENIAN ARMED FORCES - FUTURE CHALLENGES 